\title{
1 ALBA: a comprehensive growth model to optimize algae-bacteria 2 wastewater treatment in raceway ponds
}

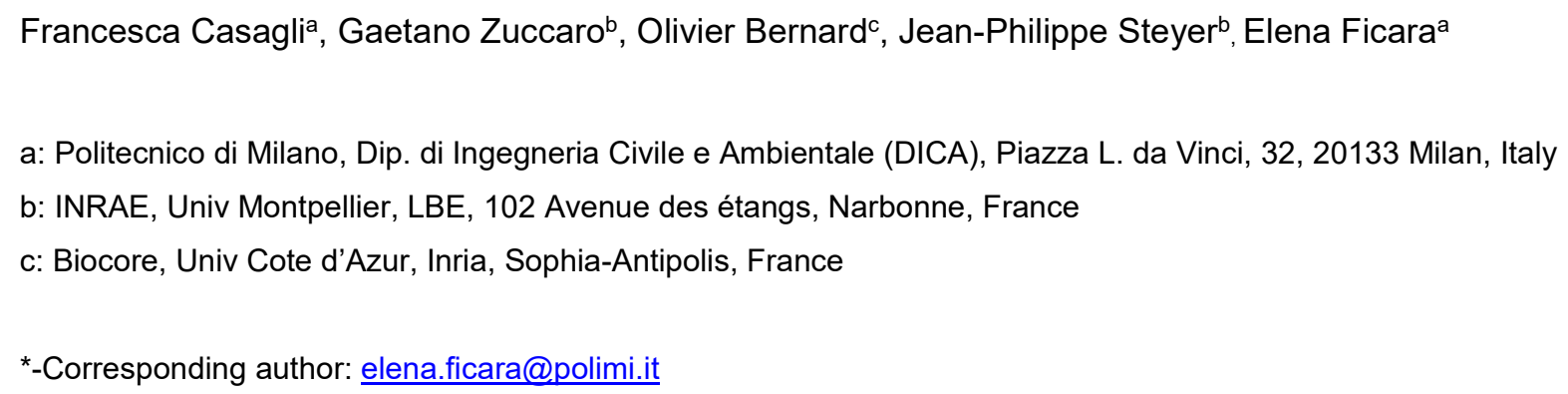

Abstract: This paper proposes a new model describing the algae-bacteria ecosystem evolution in an outdoor raceway for wastewater treatment. The ALBA model is based on a mass balance of COD, C, N and $\mathrm{P}$, but also $\mathrm{H}$ and $\mathrm{O}$. It describes growth and interactions among algae, heterotrophic and nitrifying bacteria, while local climate drives light and temperature. Relevant chemical/physical processes are also included. The minimum-law was used as ground principle to describe the multi-limitation kinetics. The model was setup and calibrated with an original data set recorded on a $56 \mathrm{~m}^{2}$ raceway located in the South of France, continuously treating synthetic wastewater. The main process variables were daily measured along 443 days of operations and dissolved $\mathrm{O}_{2}$ and $\mathrm{pH}$ were on-line recorded. A sub-dataset was used for calibration and the model was successfully validated, along the different seasons over a period of 414 days. The model proved to be effective in reproducing both the short term nycthemeral dynamics and the long-term seasonal ones. The analysis of different scenarios reveals the fate of nitrogen and the key role played by oxygen and $\mathrm{CO}_{2}$ in the interactions between the different players of the ecosystem. On average, the process turns out to be $\mathrm{CO}_{2}$ neutral, as compared to a standard activated sludge where approximately half of the influent carbon will end up in the atmosphere. The ALBA model revealed that a suboptimal regulation of the paddle wheel can bring to several detrimental impacts. At high velocity, the strong aeration will reduce the available oxygen provided by photo-oxygenation, while without aeration, it can rapidly lead to oxygen inhibition of the photosynthetic process. On the other hand, during night, the paddle wheel is fundamental to ensure enough oxygen in the system to support algal-bacteria metabolism. The model can be used to support advanced control strategies, including smart regulation of the paddle wheel velocity to more efficiently balance the mixing, aeration and degassing effects.

Keywords: Modelling; Microalgae; Wastewater; Long-Term Validation; Raceway; Mass transfer rate 


\section{Introduction}

35 The use of microalgae for wastewater treatment was first studied in the 50s (Oswald et al., 1957) and more recently revisited, in view of a more sustainable and circular approach to bioremediation (Muñoz and

37 Guieysse, 2006; Cai et al., 2013). Indeed, when applied to wastewater treatment, these microscopic photosynthetic organisms contribute to reduce the energy demand by supplying the oxygen through photosynthesis. Moreover, microalgae assimilate inorganic nitrogen and phosphorus and thus participate to the treatment process. Compared to classical activated sludge processes, algae will also recycle the carbon dioxide produced by bacteria, reducing the greenhouse gas emissions (Arashiro et al., 2018). Moreover, some algal species can contain high amounts of lipids, protein or other compounds that become elemental bricks for green chemistry (Chew et al., 2017). Microalgae appear then as new players to recycle nitrogen and phosphorus using the solar energy and providing useful products such as biofuel, bioplastics, or biofertilizer (Uggetti et al., 2014, Arias et al., 2019).

However, challenges must still be addressed to benefit from the key advantages of involving microalgae in wastewater treatment. Facing seasonal fluctuations of light and temperature is particularly difficult, especially to keep an effective algal activity at low temperatures and light during winter. Moreover, promises of the microalgae-based technology have rarely been quantified, mainly because most of the underlying processes are not easily measurable. For example, the balance between oxygen production by photosynthesis, consumption by bacterial respiration, and the role of the oxygen exchange with the atmosphere was never fully assessed. On top of this, estimating the benefits and costs based on non-optimised pilots run over a yearlong period is challenging and requires expensive field testing and data collection. All these open questions can be effectively addressed with the support of numerical simulations once a reliable model is made available (Shoener et al., 2019).

Mathematical models can indeed be used to quantify the mass and energy fluxes, and eventually optimise the process from design to operation. An accurate model is a very powerful tool to identify the most efficient operating modes, and then run an environmental or economic analysis. Modelling has demonstrated its power in many fields of biotechnology, and especially in wastewater treatment where the ASMs and ADM1 models (Henze et al., 2000; Batstone et al., 2002) are currently used at industrial scale.

The challenge for microalgal based wastewater treatments is that currently, no comprehensive models have been validated over a yearly period and applied to different case studies. 
Designing and validating a mathematical model that would be able to keep a coherent behaviour despite the nychthemeral and seasonal changes in light, temperature, rain and wind is indeed particularly challenging. Up to now, only models describing bacteria-based systems for wastewater treatment were more extensively studied and were indeed validated on longer time scales (Van Loosdrecht et al., 2015).

Few models have already been developed for simulating algae-bacteria interactions in outdoor systems. The RWQM1 (Reichert et al., 2001) was developed for modelling wastewater discharge in a river, while BioAlgae2 (Solimeno et al., 2019) describes the dynamics in a raceway reactor. Models are available for simulating indoor reactors, as PHOBIA (Wolf et al., 2007) and the Modified ASM3 (Arashiro et al., 2017). A recent detailed comparison among available algae models can be found in Shoener et al. (2019) and it has been expanded for algae-bacteria models in Supporting Information (Table SI.11).

The aim of this work is to develop a global model, integrating the main chemical, physical and biological processes taking place in outdoor systems of algae-bacteria consortia treating wastewater. The model which was initially presented in Casagli et al. (2019) shares some common choices with the above cited algaebacteria models, in particular with the ones simulating outdoor environments (RWQM1 and BioAlgae2). However, several aspects were modelled with a different/innovative approach, and especially: i) the philosophy of biological kinetics in the ALBA model, that is based on the Liebig's minimum law (De Baar, 1994); ii) the $\mathrm{pH}$ sub-model including a detailed chemical speciation and implemented by an algebraic system; iii) the sensitivity analysis procedure, based on seasonal data elaborations and simulations; iv) the conditions under which the model was calibrated and validated (including sub-optimal conditions, such as winter); v) the evaluation of the evaporation process and of its effect on dissolved and suspended compounds. A more detailed description and comparison of the modelling choices can be found in Section 5.1 and in Table SI.11.

The ALBA model describes growth and interactions among algae, heterotrophic and nitrifying bacteria, accounting for carbon, nitrogen and phosphorous fluxes. Local climate drives light, temperature and eventually the whole process dynamics. The model was developed balancing realism and complexity, so that an efficient calibration procedure was possible. The key objective was to validate the model both on short (nychthemeral) and long-term (seasonal) datasets. Fifteen months of an original field-testing campaign on an outdoor demonstrative raceway pond treating a synthetic wastewater were then used for supporting model calibration and validation along the four seasons.

The paper is structured as follows: first the experimental dataset is presented, then model structure and the main hypotheses are explained. Nychthemeral simulations of $\mathrm{pH}$ and oxygen are compared to experimental 
data. Long term predictions are compared with data from the monitoring campaign through the different seasons. The key-role of oxygen and $\mathrm{pH}$ in microbial interactions is analysed. The fate of nitrogen within the system is discussed and the actual role of microalgae for providing oxygen to bacteria is discussed in comparison with the effect of the paddle wheel for aeration. Finally, the advantages of including microalgae in the wastewater treatment process are quantified and discussed.

\section{Material and methods}

\subsection{Experimental set up and data collection}

The outdoor High Rate Algal Bacterial Pond (HRABP) of $17 \mathrm{~m}^{3}$ was located in Narbonne, France (INRAELBE, Latitude: 43.15656 , Longitude: 2.994438$)$. The total surface area was $56 \mathrm{~m}^{2}$ with a length of $15 \mathrm{~m}$ and a water depth of $0.3 \mathrm{~m}$. The reactor was mixed with a paddle wheel (resulting linear velocity of $0.2 \mathrm{~m} \mathrm{~s}^{-1}$ ) and an additional pump (flow rate $182 \mathrm{~m}^{3} \mathrm{~d}^{-1}$, located at the opposite side from the wheel).

The raceway was operated in chemostat mode, from 15/05/2018 to $01 / 08 / 2019$. The inflow rate was set to operate at an HRT of 5 days along the whole period, except from one month (29/08/2018-29/09/2018) during which different HRT values (2 and 10 days) were tested. The outflow was implemented by gravity overflow. The HRABP was equipped with dissolved oxygen (METTLER TOLEDO InPro 6850i), temperature and pH (METTLER TOLEDO InPro4260(i)/SG/425) probes. In addition, data from an ultrasonic distance sensor measuring the liquid level (Siemens, 7ML5221-1BB11) were available. Incident light at the reactor surface was measured with a PAR probe (PAR 2625 SKYE). Online measurements were collected every five minutes using the SILEX-LBE system (INRAE-LBE, France).

The reactor was inoculated with a microalgae suspension, where Chlorella sp. and Scenedesmus sp. were the dominant algal species. It was fed on a synthetic medium, mimicking a municipal wastewater (Nopens et al., 2001, Table 1), including complex organic nutrient sources (starch, milk powder, yeast, peptone). In this wastewater, the main source of nitrogen is urea, while inorganic carbon comes from the tap water used for influent dilution. Nitrite and nitrate concentrations were negligible $\left(<0.3 \mathrm{mg} \mathrm{L}^{-1}\right)$.

Table 1. Average influent characteristics and number of experimental samples (n).

\begin{tabular}{ccccc}
\hline Measurement & Sample & Unit & Mean \pm St.Dev. & $\mathbf{n}$ \\
\hline \multirow{2}{*}{$\mathrm{COD}$} & Unfiltered & $\mathrm{mgCOD} \mathrm{L}^{-1}$ & $378 \pm 57.2$ & 41 \\
& Filtered $(0.45 \mu \mathrm{m})$ & $\mathrm{mgCOD} \mathrm{L}^{-1}$ & $242 \pm 66.2$ & 41 \\
$\mathrm{BOD}_{20}$ & Unfiltered & $\mathrm{mgBOD} \mathrm{L}^{-1}$ & $357 \pm 18.7$ & 3 \\
& Filtered $(0.45 \mu \mathrm{m})$ & $\mathrm{mgBOD} \mathrm{L}^{-1}$ & 224 & 1 \\
\multirow{2}{*}{ Total nitrogen } & Unfiltered & $\mathrm{mgN} \mathrm{L}^{-1}$ & $68 \pm 12.7$ & 39 \\
& Filtered $(0.45 \mu \mathrm{m})$ & $\mathrm{mgN} \mathrm{L}^{-1}$ & $62 \pm 12.3$ & 39
\end{tabular}




\begin{tabular}{ccccc} 
& Unfiltered & $\mathrm{mgP} \mathrm{L}^{-1}$ & $15 \pm 3.2$ & 41 \\
$\mathrm{P}^{-} \mathrm{PO}_{4}{ }^{3-}$ & Filtered $(0.45 \mu \mathrm{m})$ & $\mathrm{mgP} \mathrm{L}^{-1}$ & $13 \pm 3.1$ & 41 \\
$\mathrm{~N}^{-N H_{4}}{ }^{+}$ & Filtered $(0.45 \mu \mathrm{m})$ & $\mathrm{mgN} \mathrm{L}^{-1}$ & $8 \pm 2$ & 30 \\
Alkalinity & Filtered $(0.45 \mu \mathrm{m})$ & $\mathrm{mgCaCO}_{3} \mathrm{~L}^{-1}$ & 270 & 1 \\
\hline
\end{tabular}

Optical density at $680 \mathrm{~nm}$ was assessed every $1-3$ days with a spectrophotometer (Helios Epsilon, Thermo Scientific) in a $1 \mathrm{~cm}$ optical path length cuvette.

The TSS were estimated using Whatman GF/F glass microfiber filters $\left(105^{\circ} \mathrm{C}\right)$, according to standard methods (APHA, 2017). COD measurements were performed using tube tests (Tintometer GmbH, Aqualytic AL200). Inorganic nitrogen forms were evaluated through ion chromatography (DIONEX ICS-3000, Thermo Scientific). TN and orthophosphates were measured by spectrophotometry with test kits (Hach Lange LCK338 and LCK348 respectively).

Air temperature, wind speed and relative humidity were taken from the nearby weather station of Béziers (Latitude: 43.3235, Longitude: 3.3539 ), about $30 \mathrm{~km}$ away. Local rain rate was on-site recorded. The weather dataset is presented in Supplementary Information SI.9.

The light extinction coefficient inside the pond was estimated from four dedicated tests performed with an immerged PAR probe (see Supplementary Information SI.1.1).

Standard deviations for on-line probes are computed using the probe variation coefficient (see Table SI.2.1). The variation coefficients for off-line measurements represented on the graphs are given in Table SI.2.1, in line with measurement accuracy and triplicate measurements.

\subsection{Numerical tools}

AQUASIM was used as numerical platform (Reichert, 1994). The HRABP was modelled as a completely mixed reactor compartment. Raceways mixed by paddle wheels are generally considered to be perfectly mixed (Solimeno et al., 2017). This hypothesis was validated by experimental measurements for the raceway used in this study (Hreiz et al., 2014) .

The bioprocesses dynamics is described by means of the Petersen stoichiometric and kinetic matrix, following the ASMs notation and structure, while the chemical processes are described as equilibrium processes (algebraic equation system, see SI.6.1). The model was designed to guaranty the elemental conservation of $\mathrm{C}, \mathrm{N}, \mathrm{P}, \mathrm{H}, \mathrm{O}$ and $\mathrm{COD}$ through the continuity check, that was carried out using the stoichiometric and the composition matrix (see Tables SI.3.1, SI.3.2 and SI.3.3). 
The ordinary differential equations (biological and transfer rates) and the algebraic equations (chemical equilibria) are numerically integrated according to the DASSL algorithm (Petzold, 1982) implemented in AQUASIM.

\subsubsection{Scenario analysis}

In this scenario analysis the idea is to represent the typical meteorological patterns characterizing each season. Specifically, the weather was represented for each season (spring, summer, autumn and winter) by a typical daily pattern for temperature, light and evaporation rate (see Figure 1). Four meteorological scenarios were thus computed from local meteorological data by averaging hourly values (see Section 2.1). Constant influent characteristics were assumed (as in Table 1). These realistic scenarios were used as a basis to estimate the average fluxes and relevant quantities along each season. In this way, a typical daily pattern was defined (Figure 1) and extended to run simulations under the established periodic regime. For each season, two scenarios for the gas transfer rate were considered, representing two extreme solutions for mixing the process.

The existing Algae-Bacteria models do not consider the contributions of rain and evaporation rates, even if these two phenomena can significantly affect the hydraulic balance of the raceway (Bechet et al., 2018; Pizzera et al., 2019). Indeed, the hydraulic loads are strongly affected by the meteorology, causing considerable dilution or concentration of soluble and particulate compounds inside the reactor, therefore affecting bioprocess rates as well as light availability. The evaporative contribution was estimated according to the Buckingham equation (Bechet et al., 2011). Long term simulations were then run under periodic regime, until a steady periodic response was reached. Results are shown and discussed in section 5.2.

\subsubsection{Sensitivity analysis}

The sensitivity analysis was carried out with the available AQUASIM toolboxes (Reichert, 1994), using the long-term dataset from the monitoring campaign.

The absolute-relative sensitivity function was chosen to facilitate the comparison among the effect of different parameters on the same dynamic variable. In addition, a ranking of the absolute values of the sensitivity functions was implemented. The sensitivity function was studied for each season, considering the stationary periodic regime. 

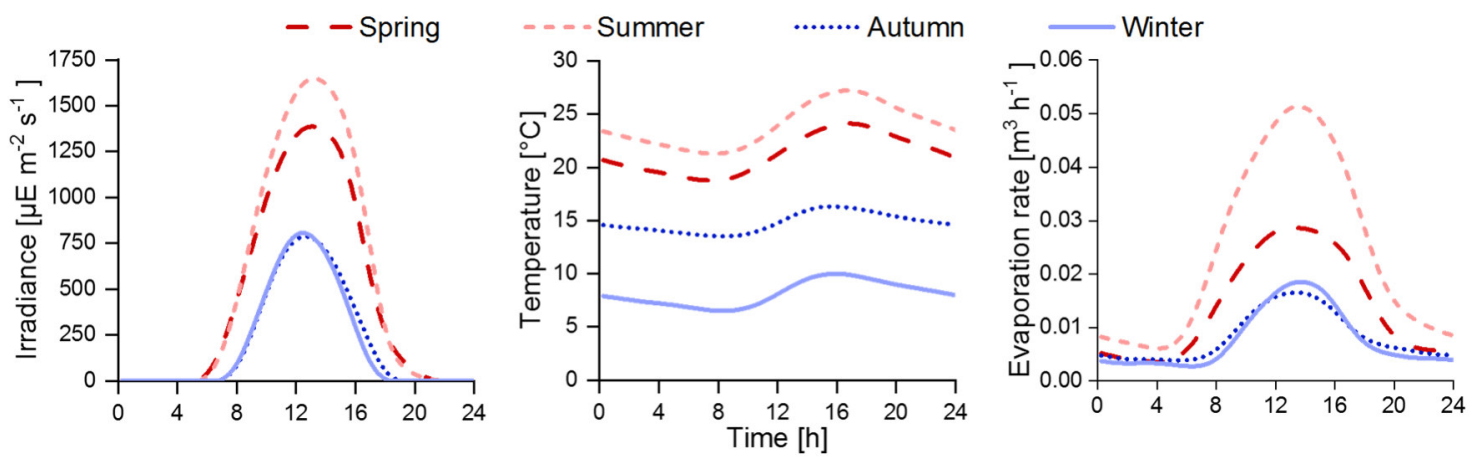

Figure 1. Typical daily pattern of temperature, irradiance and evaporation rates according to the season

\subsubsection{Parameters identification}

First, simulations were run choosing model parameter values inside the ranges reported in similar works in literature (see Table SI.8.1). A pre-calibration was first made by expert adjustment of these parameters to get an overall coherent simulated dynamics over the full period. These parameter values where then taken as initial conditions for the automatic fine-tuning parameter identification algorithm performed on the targeted sub-set of parameters obtained from the sensitivity analysis.

The identification toolbox of AQUASIM was used which minimizes the sum of square errors between simulated and experimental data weighted by standard deviations (Reichert, 1994):

$$
x^{2}(p)=\sum_{i=1}^{n}\left(\frac{y_{m, i}-y_{s, i}(p)}{\sigma_{m, i}}\right)^{2}
$$

Where $n$ is the number of measurements, $y_{m, i}$ and $y_{s, i}$ are the experimental and simulated variables respectively, $\sigma_{\mathrm{m}, \mathrm{i}}$ the deviation standard of experimental measurements and $\mathrm{p}$ is the parameter to be determined to minimize the difference among experimental measurements and model predictions. The simplex method was used to find a first set of optimized solutions, while the secant method was applied to further reduce the prediction error (Reichert, 1994).

Since the current parameter values in the literature account for situations in spring or summer (or indoor at warmer temperature), the calibration strategy had to counterbalance this inherent model ability to better represent the warmest seasons. Indeed, the default parameter values are taken from algae-bacteria models typically calibrated on a short-term period, under spring-summer or indoor conditions, resulting in limited applicability range of the model. Two calibration periods were thus chosen in autumn and winter (02$21 / 10 / 2018$ and $01-10 / 01 / 2019$ ) in order to cover a wider range of temperatures and weather conditions. No 
additional calibration periods were considered to avoid a further reduction of the data for the validation phase.

Since a correct prediction of $\mathrm{pH}$ and $\mathrm{O}_{2}$ is crucial to precisely predict the overall system dynamics, and since these signals are directly or indirectly affected by all relevant biochemical and physical/chemical processes, the online $\mathrm{pH}$ and $\mathrm{O}_{2}$ measurements were used as first target in the parameter estimation to get an upgraded set of parameters. The information richness of this fluctuating signals revealed to be very beneficial for an accurate calibration of ammonium, nitrite, nitrate, COD, optical density and TSS predictions. Expert adjustment from the previous parameter set was then carried out to further improve the fit of the off-line measurements. The procedure was repeated iteratively until a good fit was obtained for the calibration period. A unique set of parameters was finally obtained and considered to simulate the experimental campaign covering all seasons. The parameter uncertainty was derived from the Fisher information matrix, as described in SI.9. The prediction error was derived from the parameter uncertainty and from the sensitivity functions, as detailed in in SI.10.

Model validity was then assessed using the data of the monitoring campaign which were not used during calibration (i.e. data from 414 days, out of 443 days).

\subsubsection{Quality of fit}

Model prediction performances were evaluated through the modified Theil's Inequality Coefficient, TIC, (Decostere at al., 2016) and the modified Mean Absolute Relative Error, MARE, (Hauduc et al., 2015) as reported in Eq. 2 and 3:

$$
\begin{gathered}
\text { TIC }=\frac{\sqrt{\sum_{\mathrm{i}}\left(\mathrm{sat}_{\sigma}\left(\mathrm{y}_{\mathrm{s}, \mathrm{i}}, \mathrm{y}_{\mathrm{m}, \mathrm{i}}\right)\right)^{2}}}{\sqrt{\sum_{\mathrm{i}} \mathrm{y}_{\mathrm{s}, \mathrm{i}}^{2}}+\sqrt{\sum_{\mathrm{i}} \mathrm{y}_{\mathrm{m}, \mathrm{i}}^{2}}} \\
\text { MARE }=\frac{1}{\mathrm{n}} \cdot \sum_{\mathrm{i}=1}^{\mathrm{n}} \frac{\left|\mathrm{sat}_{\sigma}\left(\mathrm{y}_{\mathrm{m}, \mathrm{i}}, \mathrm{y}_{\mathrm{s}, \mathrm{i}}\right)\right|}{\mathrm{y}_{\mathrm{m}, \mathrm{i}}+\varphi}
\end{gathered}
$$

Where the function sat ${ }_{\sigma}\left(\mathrm{y}_{\mathrm{s}, \mathrm{i}}, \mathrm{y}_{\mathrm{m}, \mathrm{i}}\right)$ is zero when both $y_{m, i}$ and $y_{s, i}$ are lower than the associated measurement standard deviation (accepted as perfect fit situation), and otherwise: $\operatorname{sat}_{\sigma}\left(\mathrm{y}_{\mathrm{s}, \mathrm{i}} \mathrm{y}_{\mathrm{m}, \mathrm{i}}\right)=\mathrm{y}_{\mathrm{s}, \mathrm{i}}-\mathrm{y}_{\mathrm{m}, \mathrm{i}}$. The small correction factor $\varphi$ (taken as 0.1 ) is applied to avoid division by zero.

Both criteria quantify the difference between model predictions and experimental values and normalize them according to the magnitude of the considered variable. For both criteria, the closer the value to zero, the 
better the model performance. The TIC and MARE criteria were computed for the measured variables on the overall validation period (excluding the dataset used for calibration) and separately for each season.

\section{ALBA model description}

\subsection{Biological model}

The ALBA model includes 19 biological processes involving 17 state variables, classified as shown in Table

2. Reaction stoichiometry and rates are inspired by standard modelling works. However, some simplifications were adopted to limit the complexity of this multiscale dynamic system, the main ones being listed hereafter. First, the soluble organic biodegradable matter $\left(\mathrm{S}_{\mathrm{s}}\right)$ was assumed to be consumed only by heterotrophic bacteria, even though most of the microalgae can grow heterotrophically or mixotrophically, at least for some simple and easily biodegradable carbon sources such as glucose or acetate (Turon et al., 2015). However, more complex carbon sources can be typically found in wastewaters (e.g. municipal and industrial waste streams, digestate) and algae are generally not able to use them for their metabolism, or just a small fraction of the algal population may be equipped with the suitable enzymes. For this reason, in the ALBA model it was assumed that the algal growth is only autotrophic. In addition, the heterotrophic/mixotrophic algal metabolism is still not well characterized for outdoor and non-axenic conditions, making the calibration of key parameters more challenging (e.g. specific growth rate, affinity to specific substrate, dependence on environmental conditions, etc.).

Predation was not explicitly considered and it was integrated into the mortality term. Organic matter and nutrient storage processes as intermediate step for biomass growth were not considered. Hydrolysis processes, both for urea and slowly biodegradable COD, are assumed to be performed by heterotrophic bacteria only. Consistently with experimental records for real and synthetic wastewaters, micronutrients were assumed to be abundant and never limiting. $\rho_{1}$ - Algae phototrophic growth using $\mathrm{NH}_{4}{ }^{+}$as nitrogen source. Inorganic carbon is used under the form of $\mathrm{CO}_{2}$ and $\mathrm{HCO}_{3}$ and oxygen is produced, while soluble phosphorous and ammonium are uptaken. $\rho_{2}$ - Algae phototrophic growth, using $\mathrm{NO}_{3}^{-}$as nitrogen source. This is not the favoured way for growing, since it requires more energy. Therefore, it takes place when ammonium is limiting. Main products are biomass and oxygen, while inorganic carbon, nitrate, and phosphorus are consumed. 
$\rho_{3}-$ Algae respiration. This process accounts for biomass loss, with oxygen consumption and production of $\mathrm{CO}_{2}$. Typically, in ASM models, there is only one process to account for either endogenous respiration or decay. Here, these two processes are distinguished, assuming oxygen consumption occurs only during respiration.

$\rho_{4}-$ Microalgae decay, without oxygen consumption, releasing nutrients and organic matter, in line with other algae-bacteria models (RWQM1 and BioAlgae2).

$\rho_{5}-$ Aerobic growth of heterotrophic bacteria using $\mathrm{NH}_{4}{ }^{+}$as nitrogen source. This is the preferential way for growth under aerobic conditions. Growth also requires a source of carbon and energy (soluble organic matter), phosphorus and oxygen and results in $\mathrm{CO}_{2}$ production.

$\rho_{6}-$ Aerobic growth of heterotrophic bacteria on $\mathrm{NO}_{3}{ }^{-}$as nitrogen source. This is a secondary way for growth of heterotrophs under aerobic conditions when ammonium is limiting, but it requires more energy leading to a lower growth yield.

$\rho_{7}-$ Aerobic respiration of heterotrophic bacteria (same assumptions as for algae).

$\rho_{8}-$ Anoxic growth of heterotrophic bacteria using $\mathrm{NO}_{3}{ }^{-}$as electron acceptor. This reaction occurs when oxygen is not available.

$\rho_{9}-$ Anoxic growth of heterotrophic bacteria on $\mathrm{NO}_{2}^{-}$as election acceptor. As for process $\rho_{8}$, this reaction occurs only when oxygen concentration becomes too low.

$\rho_{10}-$ Anoxic respiration of heterotrophic bacteria, using $\mathrm{NO}_{2}^{-}$and $\mathrm{NO}_{3}{ }^{-}$instead of $\mathrm{O}_{2}$ as electron acceptor. It takes place only for low concentrations of Dissolved Oxygen (DO).

$\rho_{11}-$ Hydrolysis of slowly biodegradable organic matter. This process is performed by heterotrophic bacteria through an enzymatic reaction, where complex organic substances are transformed into readily assimilable $\rho_{12}$ - Hydrolysis of urea. This is an enzymatic reaction performed by heterotrophs, without oxygen consumption, transforming urea into ammoniacal nitrogen and $\mathrm{CO}_{2}$.

$\rho_{13}-$ Decay of heterotrophic bacteria, modelled similarly to algae decay.

$\rho_{14}-$ Aerobic growth of AOB. In line with the approach followed by lacopozzi et al. (2007) and in the RWQM1 model, the two-step nitrification process has been implemented to reproduce the accumulation of nitrite observed experimentally. It involves oxygen consumption for ammonium oxidation into nitrite, from which the 
energy necessary for AOB growth is derived. Inorganic carbon is used as carbon source and phosphorus is uptaken.

$\rho_{15}-$ Aerobic respiration of $\mathrm{AOB}$, similarly to algae respiration.

$\rho_{16}-$ Decay of AOB, modelled similarly to algae decay.

$\rho_{17}-$ Aerobic growth of NOB. Oxygen is used for nitrite oxidation to nitrate to get the energy for biomass production. Inorganic carbon is used as carbon source and phosphorus is uptaken.

$\rho_{18}-$ Aerobic respiration of NOB, similarly to algae respiration.

$\rho_{19}-$ Decay of NOB, modelled similarly to algae decay.

Bioprocess stoichiometry and kinetics are described in the following Sections 3.1.1 and 3.1.2.

\subsubsection{Bioprocess stoichiometry}

One of the originalities of the ALBA model is to describe the phototrophic growth of microalgae considering the main nutrients and metabolites $\left(\mathrm{CO}_{2}, \mathrm{HCO}_{3}{ }^{-}, \mathrm{NH}_{4}{ }^{+}, \mathrm{PO}_{4}{ }^{3-}, \mathrm{O}_{2}\right)$ affecting their kinetics. The algae biomass elementary composition is taken from Grobbelaar (2004), accounting for $\mathrm{C}, \mathrm{H}, \mathrm{O}, \mathrm{N}, \mathrm{P}$ and neglecting micronutrients (e.g.: Fe, Mg). The source of inorganic nitrogen is assumed to be ammonium or nitrate. Reaction stoichiometry for algae growth on ammonium and nitrate is reported in Supplementary information, Table SI.3.1. It is worth emphasising that the ALBA model accounts for P assimilation while existing models do rarely consider $\mathrm{P}$ in the biomass raw formula. Moreover, the design of the model guarantees the elemental conservation of $\mathrm{C}, \mathrm{N}, \mathrm{P}, \mathrm{H}, \mathrm{O}$ and the $\mathrm{COD}$ conservation. All the stoichiometric parameter values and their expressions as implemented in the stoichiometric matrix, can be found in Supp. Info (Table SI.3.2 and SI.3.3).

305 
Table 2. State variables included in the ALBA model.

\begin{tabular}{|c|c|c|c|c|c|}
\hline \multicolumn{6}{|c|}{ State variables } \\
\hline & & & Symbol & Description & Unit \\
\hline \multirow{4}{*}{ 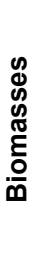 } & \multirow{6}{*}{$\begin{array}{l}\widehat{x} \\
0 \\
\frac{\pi}{J} \\
\frac{0}{J} \\
\frac{ \pm}{\pi} \\
0\end{array}$} & 1 & $\mathrm{X}_{\mathrm{ALG}}$ & Phototrophic algae & $\mathrm{gCOD} \mathrm{m}^{-3}$ \\
\hline & & 2 & $\mathrm{X}_{\mathrm{AOB}}$ & Ammonium Oxidising Bacteria (AOB) & $\mathrm{gCOD} \mathrm{m}^{-3}$ \\
\hline & & 3 & $\mathrm{X}_{\mathrm{NOB}}$ & Nitrite Oxidising Bacteria (NOB) & $\mathrm{gCOD} \mathrm{m}^{-3}$ \\
\hline & & 4 & $\mathrm{X}_{\mathrm{H}}$ & Heterotrophic bacteria & $\mathrm{gCOD} \mathrm{m}^{-3}$ \\
\hline \multirow{13}{*}{ 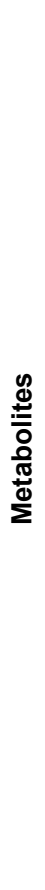 } & & 5 & $X_{S}$ & Slowly biodegradable organic matter & $\mathrm{gCOD} \mathrm{m}^{-3}$ \\
\hline & & 6 & $X_{1}$ & Inert particulate organic matter & $\mathrm{gCOD} \mathrm{m}^{-3}$ \\
\hline & \multirow{11}{*}{$\begin{array}{l}\overline{0} \\
\frac{0}{0} \\
\frac{0}{3} \\
\text { க) }\end{array}$} & 7 & $\mathrm{~S}_{\mathrm{s}}$ & Readily biodegradable organic matter & $\mathrm{gCOD} \mathrm{m}^{-3}$ \\
\hline & & 8 & $\mathrm{~S}_{\mathrm{I}}$ & Inert soluble organic matter & $\mathrm{gCOD} \mathrm{m}^{-3}$ \\
\hline & & 9 & $\mathrm{~S}_{\mathrm{IC}}$ & Total inorganic carbon: sum at the equilibrium of $\mathrm{CO}_{2}, \mathrm{HCO}_{3}{ }^{-}, \mathrm{CO}_{3}{ }^{2-}$ & $\mathrm{gC} \mathrm{m}^{-3}$ \\
\hline & & 10 & $\mathrm{~S}_{\mathrm{ND}}$ & Organic nitrogen & $\mathrm{gN} \mathrm{m}^{-3}$ \\
\hline & & 11 & $\mathrm{~S}_{\mathrm{NH}}$ & $\begin{array}{l}\text { Total Ammoniacal Nitrogen (TAN): sum at the equilibrium of } \mathrm{NH}_{3} \text { and } \\
\mathrm{NH}_{4}{ }^{+}\end{array}$ & $\mathrm{gN} \mathrm{m}^{-3}$ \\
\hline & & 12 & $\mathrm{~S}_{\mathrm{NO} 2}$ & Nitrous nitrogen: sum at the equilibrium of $\mathrm{NO}_{2}^{-}, \mathrm{HNO}_{2}$ & $\mathrm{gN} \mathrm{m}^{-3}$ \\
\hline & & 13 & $\mathrm{~S}_{\mathrm{NO} 3}$ & Nitric nitrogen: sum at the equilibrium of $\mathrm{NO}_{3}{ }^{-}, \mathrm{HNO}_{3}$ & $\mathrm{gN} \mathrm{m}^{-3}$ \\
\hline & & 14 & $\mathrm{~S}_{\mathrm{N} 2}$ & Nitrogen gas & $\mathrm{gN} \mathrm{m}^{-3}$ \\
\hline & & 15 & $\mathrm{~S}_{\mathrm{PO} 4}$ & $\begin{array}{l}\text { Total inorganic phosphorous: sum at the equilibrium of } \mathrm{PO}_{4}{ }^{3-}, \mathrm{HPO}_{4}{ }^{2-} \\
, \mathrm{H} 2 \mathrm{PO}^{4-}, \mathrm{H}^{2} \mathrm{PO}^{4}\end{array}$ & $\mathrm{gP} \mathrm{m}^{-3}$ \\
\hline & & 16 & $\mathrm{~S}_{\mathrm{O} 2}$ & Dissolved oxygen & $\mathrm{gO} 2 \mathrm{~m}^{-3}$ \\
\hline & & 17 & $\mathrm{~S}_{\mathrm{H} 2 \mathrm{O}}$ & Water & $\mathrm{gH} \mathrm{m}^{-3}$ \\
\hline
\end{tabular}

\subsubsection{Bioprocess kinetics}

309 The process rates are described in Table 3, ( $\rho_{\mathrm{i}}$, where $i$ is the process number, as listed before). Every rate accounts for the effect of nutrient concentration (limitation or inhibition) and of environmental conditions

311 (light, temperature, $\mathrm{pH}$ ) through the product of Monod terms and dedicated relationships ( $\mathrm{f}_{\mathrm{l}}, \mathrm{f}_{\mathrm{T}}, \mathrm{f}_{\mathrm{pH}}, \mathrm{fo}_{\mathrm{o}, \mathrm{G}}$, fo2,D). A special focus on these mathematical expressions is reported below. 


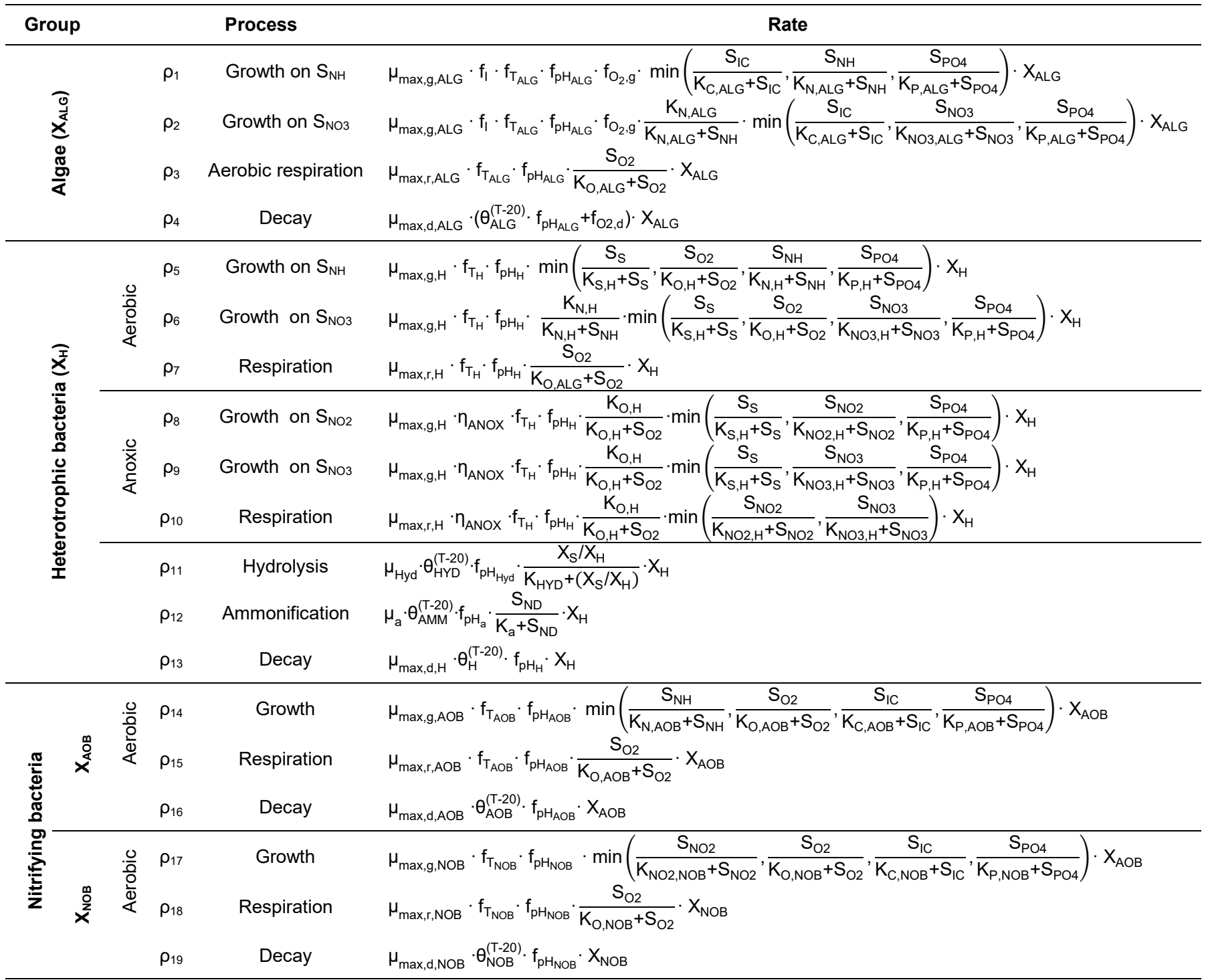

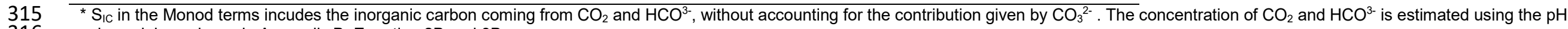
316 sub-model, as shown in Appendix B, Equation 2B and 3B. 


\section{Nutrients}

318 The ASMs models generally adopt a Monod type function to describe nutrient dependence in biological kinetics requiring two parameters $\left(\mu_{\max }, \mathrm{K}_{\mathrm{s}}\right)$. Often, nutrient dependence has been modelled in literature by multiplying the different limiting functions. The use of these conventional multiplicative Monod terms is well known to overestimate the growth limitation in presence of multiple limiting nutrients, therefore the Liebeg's minimum law was preferred to be closer to reality (Bougaran et al. 2010, Dolman and Wiedner 2015), especially when simulating sub-optimal conditions in terms of substrate availability for the different biomasses. The minimum law assumes (Lee et al., 2015) that the most limiting nutrient drives the growth kinetics.

This approach was applied for the limiting substrates only but not for light, temperature or pH (Equation 4). In modelling the effect of nutrient inhibition on biomass growth (see processes $\rho_{2}, \rho_{6}, \rho_{8}, \rho_{9}, \rho_{10}$ in Table 3 ), a hyperbolic-inhibition function was chosen, in line with the approach used in both ASMs and ADM1. The general expression describing the biological process rates structure writes:

$$
\rho_{i, \text { growth }}=\mu_{m a x, i} \cdot f_{T, i} \cdot f_{p H, i} \cdot f_{i} \cdot \frac{K_{n}}{K_{n}+S_{n}} \cdot \min \left(\sum_{j} \frac{S_{j}}{K_{j}+S_{j}}\right) \cdot X_{B M, i}
$$

where $\mu_{\max }$ is the maximum specific growth rate $\left[\mathrm{d}^{-1}\right] ; \mathrm{fT}_{\mathrm{T}}, \mathrm{f}_{\mathrm{pH}}$ and $\mathrm{f}_{\mathrm{l}}$ are the functions describing temperature, $\mathrm{pH}$ and light dependence, respectively, detailed in the following paragraphs; $\mathrm{K}_{\mathrm{n}}$ is the inhibition constant for the inhibiting substrate $S_{n}, K_{j}$ is the half-saturation constant for the limiting substrate $S_{j}$ and $X_{B M, i}$ is the associated biomass. The specific expressions of each process are shown in Table 3.

Light is a crucial factor for algae growth, driving a large fraction of the energy and carbon fluxes in the system. Describing its effect on photosynthesis in a turbid system is challenging since it is affected by many different factors and it is species dependent (Martinez et al. 2018). As stated before, light penetration in the HRABP was estimated through the Lambert-Beer law (see Equation SI.1.1) and the light extinction coefficient $(\varepsilon)$ was experimentally determined, as reported in supplementary information (SI 1). parametrization proposed by Bernard and Remond (2012). 


$$
f_{\mathrm{l}}=\mu_{\mathrm{MAX}} \frac{\mathrm{l}}{1+\frac{\mu_{\mathrm{MAX}}}{\alpha}\left(\frac{\mathrm{l}}{\mathrm{I}_{\mathrm{OPT}}}-1\right)^{2}}
$$

346

347 This function includes three parameters: maximum specific growth rate $\left(\mu_{\max }\right)$, optimal light for growth (loPT) and the initial slope of light response curve ( $\alpha$ ). The values chosen for lopt and $\alpha$ are close to those reported in similar works (Martinez et al., 2018; Rossi et al., 2020), while $\mu_{\operatorname{MAx}}$ was calibrated (see section 2.2). The function $\mathrm{f}_{\mathrm{l}}$ was integrated along the liquid depth inside the raceway (i.e. the light path), to compute the average algae growth rate as a function of the available light intensity at each depth, according to the approached followed by Martinez et al. (2018).

\section{Temperature}

Temperature deeply affects biological process rates, and this influence must definitely be considered for outdoor systems. In this study, temperature fluctuates within large ranges along the campaign period, through daily oscillations and seasonal changes.

The model chosen for simulating the temperature dependence of growth and respiration rates, both for algae and bacteria, is the CTMI (Cardinal Temperature Model with Inflection) proposed by Rosso et al. (1993), shown in Equation 6. This function has been shown to efficiently describe biomass growth, especially at high temperatures. It requires three parameters (the cardinal temperatures: $T_{M A X}, T_{O P T}, T_{M I N}$ ), which define the optimal working range for each species.

An Arrhenius function, requiring only one parameter ( $\theta$ in Equation 7 ), was implemented for modelling the decay rate dependence on temperature for both algae and bacteria. With this function, the decay rate increases with temperature. Nominal and calibrated cardinal temperature values are shown later on in Table SI.8.1.

$$
f_{T}=\left\{\begin{array}{cc}
0 & T<T \text { min } \\
\frac{\left(T-T_{M A X}\right) \cdot\left(T-T_{M I N}\right)^{2}}{\left(T_{O P T}-T_{M I N}\right) \cdot\left(T_{O P T}-T_{M I N}\right) \cdot\left[\left(T-T_{O P T}\right)-\left(T_{O P T}-T_{M A X}\right) \cdot\left(T_{O P T}+T_{M I N}-2 T\right)\right]} & T \text { min } \leq T \leq T \text { max } \\
0 & T>T \text { max } \\
f_{T}=\frac{\mu_{\text {Decay }}(T)}{\mu_{\text {Decay }}\left(20^{\circ} \mathrm{C}\right)}=\theta^{(T-20)} &
\end{array}\right.
$$


The $\mathrm{pH}$ strongly influences system dynamics, since it directly affects the speciation of soluble compounds $\left(\mathrm{S}_{\mathrm{IC}}, \mathrm{S}_{\mathrm{NH}}, \mathrm{S}_{\mathrm{NO} 2}, \mathrm{~S}_{\mathrm{NO} 3}, \mathrm{~S}_{\mathrm{PO}}\right)$ and their availability.

371 The $\mathrm{pH}$ of the raceway was not controlled, so that the system exhibited large daily $\mathrm{pH}$ fluctuations (up to 10.5 during day and down to 7 during night). The $\mathrm{pH}$ dependence was modelled using the CPM (Cardinal $\mathrm{pH}$ Model, without inflection, Equation 8) function proposed by Rosso et al. (1995). The CPM requires three parameters (the cardinal $\mathrm{pH}: \mathrm{pH}_{\mathrm{MAX}}, \mathrm{pH}_{\mathrm{OPT}}, \mathrm{pH}_{\mathrm{MIN}}$ ), defining the growing range for each biomass.

$$
f_{p H}=\left\{\begin{array}{cc}
0 & p H<p H_{M I N} \\
\frac{\left(p H-p H_{M I N}\right) \cdot\left(p H-p H_{M A X}\right)}{\left(p H-p H_{M I N}\right) \cdot\left(p H-p H_{M A X}\right)-\left(p H-p H_{O P T}\right)^{2}} & p H_{M I N} \leq p H \leq p H_{M A X} \\
0 & p H>p H_{\text {MAX }}
\end{array}\right.
$$

376

The parameters values were taken from literature (Rossi et al., 2020).

Nominal and calibrated cardinal pH values are reported in Table SI.8.1.

\section{Oxygen}

$$
f_{D O, G}=\frac{k_{D O}{ }^{n}}{S_{O 2}^{n}+k_{D O}{ }^{n}}
$$
(see Table 3). (kDo):

$$
f_{D O, D}=\frac{S_{O 2}^{n}}{S_{O 2}^{n}+k_{D O}^{n}}
$$

\subsection{Chemical and physical sub-models 3.2.1. $\mathrm{pH}$ sub-model}

High dissolved oxygen concentrations can negatively affect the photosynthetic activity of phototrophic microorganisms (Peng et al., 2013). The reduction of photosynthetic activity at high $\mathrm{O}_{2}$ concentrations can be described with an inhibition Hill-type model (Equation 9) in the growth rate (Di Veroli et al., 2015):

where $k_{D O}$ is the inhibition parameter of the model and $\mathrm{n}$ is the dimensionless Hill coefficient [-]. Oxygen is the substrate of algae respiration and its limiting effect is classically represented with a Monod-type function

The effect of high oxygen concentration on algal mortality was represented with a Hill-type model (Equation 10), as reported in Table 3. It represents the increase in the decay rate above a certain oxygen concentration 
Modelling inorganic carbon and $\mathrm{pH}$ dynamics (together with oxygen) is the cornerstone of the algae-bacteria interactions. The $\mathrm{pH}$ evolution results from the dynamical balance between the chemical, physical and biological process interactions. The $\mathrm{pH}$ model is based on dissociation equilibria and mass balances of acids and bases, as in the ADM1 (Anaerobic Digestion Model n.1, Batstone et al., 2002) and on the charge balance, through which it is possible to determine the concentration of hydrogen ions, consequently the $\mathrm{pH}$ of the system. Explicit equations and dissociation constants, together with their temperature dependency are provided in Sup. Info (Table SI.5.1). Note that the pH sub-model considers much more chemical species than the simplified $\mathrm{pH}$ models involved in the other algae-bacteria models, being therefore more appropriate for simulating case studies where the $\mathrm{pH}$ is not controlled and where extreme values can be reached.

The variable $\Delta_{C A T, A N}$ is the difference between cationic and anionic species which do not enter explicitly in the charge balance. Since none of the processes acts on $\triangle_{C A T, A N}$, its dynamics simply depends on the incoming buffering capacity.

\subsubsection{Gas - liquid transfer}

The open pond has a large surface exchanging with the atmosphere, consequently gas-liquid mass transfer $\left(\mathrm{O}_{2}, \mathrm{CO}_{2}\right.$ stripping/dissolution, $\mathrm{NH}_{3}$ stripping) must be implemented. The general expression for the mass transfer kinetics can be described through the Fick's law (Equation 11):

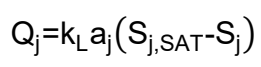

Where $Q_{j}$ is the transfer rate for the gas $S_{j}\left[g^{-3} d^{-1}\right]$, kLa is the global mass transfer coefficient $\left[\mathrm{d}^{-1}\right], S_{j}$ is the gas concentration $\left[\mathrm{g} \mathrm{m}^{-3}\right.$ and $S_{\mathrm{j}, \mathrm{SAT}}$ is the gas concentration at saturation conditions $\left[\mathrm{g} \mathrm{m}^{-3}\right]$. $S_{\mathrm{j}, \mathrm{SAT}}$ is expressed through the Henry's law (Equation 12):

$$
\mathrm{S}_{\mathrm{j}, \mathrm{SAT}}=\mathrm{H}_{\mathrm{Sj}} \cdot \mathrm{p}_{\mathrm{Sj}}
$$

where $\mathrm{H}_{\mathrm{j} j}$ is the Henry constant for the gas $\mathrm{S}_{\mathrm{j}}\left[\mathrm{g} \mathrm{m}^{-3} \mathrm{~atm}^{-1}\right]$ and $\mathrm{psj}_{\mathrm{j}}$ is the gas partial pressure at the interface [atm]. The different mass transfer coefficients and their temperature dependence are described in SI.7.

\subsubsection{Connecting simulated variable with measured quantities}

Experimental measurements of COD and TSS were compared with the simulated variables computed as follows: $T S S=\left[\left(X_{A L G} / 1.57\right)+\left(X_{I}+X_{S}+X_{A O B}+X_{N O B}+X_{H}\right) / 1.46\right]$ and $C_{S O D}=S_{S}+S_{I}$. The coefficient $1.57 \mathrm{gCOD}$ $\mathrm{gBM}_{\mathrm{ALG}^{-1}}$ and $1.46 \mathrm{gCOD} \mathrm{gBM}_{\mathrm{BAC}}{ }^{-1}$ are the conversion factors computed for algae and bacteria respectively 
using the stoichiometry described in SI. 4. Algal COD was estimated from absorption measurements using the following correlation: $\mathrm{X}_{\mathrm{ALG} \text {, meas }}=824.48^{*} \mathrm{OD}_{680}$ (See SI.1.2).

\section{Results}

\subsection{Sensitivity analysis and parameter estimation}

The large number of parameters involved in the ALBA model (135 in total, including the parameters characterizing chemical constants and their temperature dependence) is a major challenge for its calibration. A sensitivity analysis was thus needed to identify a subset of parameters among the most sensitive ones, which are then identified by the calibration procedure. Results are reported in Supp. Info Table SI.8.1. It is worth noting that all the parameters that were classified as the most sensitive ones and therefore included into the calibration procedure directly or indirectly impact the $\mathrm{pH}$ and dissolved oxygen dynamics, making these easily measurable on-line signals of great relevance in parameters identification.

Kinetic parameters related to microalgae and nitrifying bacteria were among the most sensitive ones. In particular, the maximum specific growth rate of $\mathrm{AOB}$ and $\mathrm{NOB}$ had a substantial effect on nitrogen forms, DO and $\mathrm{pH}$ dynamics.

The algal biomass concentration is highly influenced by parameters related to the photosynthesis-irradiance curve, similarly to previous findings (Rada-Ariza, 2018). Indeed, both the light extinction coefficient, the initial slope of the light response curve, and the optimal irradiance value strongly affect the predicted values of microalgae concentration, $\mathrm{DO}$ and $\mathrm{pH}$.

The mass-transfer coefficient ( $\mathrm{k}\left\llcorner\mathrm{a}\right.$ ) turned out to govern all the gas-liquid exchanges (i.e. $\mathrm{NH}_{3}, \mathrm{CO}_{2}$ and $\mathrm{O}_{2}$ ), also influencing $\mathrm{pH}$, and consequently the biological process rates and dissociation equilibria. It was therefore calibrated, with the resulting value falling in the literature range (Mendoza et al., 2013; Caia et al., 2018).

The cardinal temperatures and $\mathrm{pH}$ values in the Rosso functions were also found to be among the most sensitive parameters. For algae, the calibrated $\mathrm{T}_{\mathrm{MAX}}$ threshold is close to the nominal value, while lower values were obtained for TOPT and $\mathrm{T}_{\mathrm{MIN}}$. Regarding $\mathrm{pH}$, calibrated thresholds are close to those proposed by Ippoliti et al. (2016). The calibrated $\mathrm{pH}_{\mathrm{MIN}}$ was also experimentally observed in activity tests performed on algae-bacteria samples from a similar pilot-scale HRABP treating the liquid fraction of digestate from a waste sludge full scale digester (Rossi et al., 2020). The cardinal values for AOB and NOB are slightly different from those previously suggested for conventional activated sludge plant, where the working $\mathrm{pH}$ range is typically around neutrality. 
The coefficients for temperature dependence for organic carbon and nitrogen hydrolysis were found to remarkably influence simulation results. This is due to the key role played by temperature on these processes, which is especially relevant in systems where the availability of ammoniacal nitrogen and/or readily biodegradable organic compounds strictly depends on the hydrolysis efficiency. COD fractionation and alkalinity had also a strong impact on model results, but they can be easily measured.

\subsection{Model performances on relevant variables 4.2.1. Nycthemeral dynamics}

Model performances in reproducing daily dynamics for dissolved oxygen and $\mathrm{pH}$ are discussed in this section. For each variable, three days were selected for each season and reported in Figure 2. The selected days in autumn belong to the calibration period, to illustrate the very good model fit obtained (Figure2b). The ALBA model proved to accurately capture nycthemeral dynamics reflected in the on-line signals, as shown in Figure 2. It is worth noting that the oxygen dynamics in response to light results in more complex profiles during cloudy days (Figure $2 \mathrm{~b}$ and Figure $2 \mathrm{~d}$ ). During the night, the simulated oxygen is stable or slightly increasing, depending on the balance between higher oxygen solubility due to lower temperatures and biological consumption rates. The model confidence interval for the maximum oxygen level slightly overestimates the measured oxygen mostly in spring (Figure 2d) and during the central part of the day. In summer, oxygen production during the hours of highest irradiance is underestimated probably because of light inhibition.

During winter, the model is still efficient in predicting the dissolved oxygen dynamics, but the simulated values underestimate the real ones by about $3 \mathrm{mg} \mathrm{L}^{-1}$ (Figure 2c) suggesting that the set of calibrated parameters are less effective in capturing the winter behaviour. It must be made clear that all the simulated data were obtained with the same parameter set.

The $\mathrm{pH}$ dynamics is correctly captured in almost all the seasons. During spring 2019 , the raceway reached the highest $\mathrm{pH}$ values and the corresponding predictions are less accurate. Under those high $\mathrm{pH}$ values, other phenomena could take place, such as salts precipitation which are not included in the ALBA model but that may affect the $\mathrm{pH}$ value. 
a)

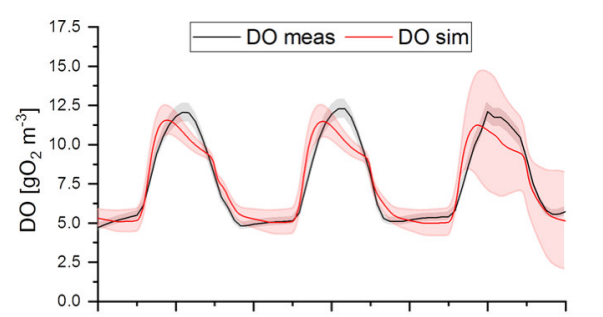

b)
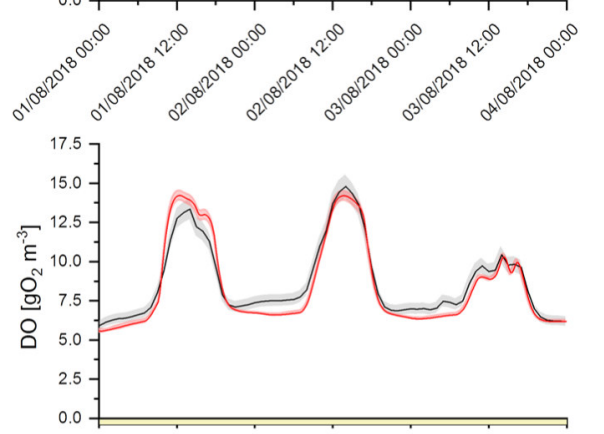

c)
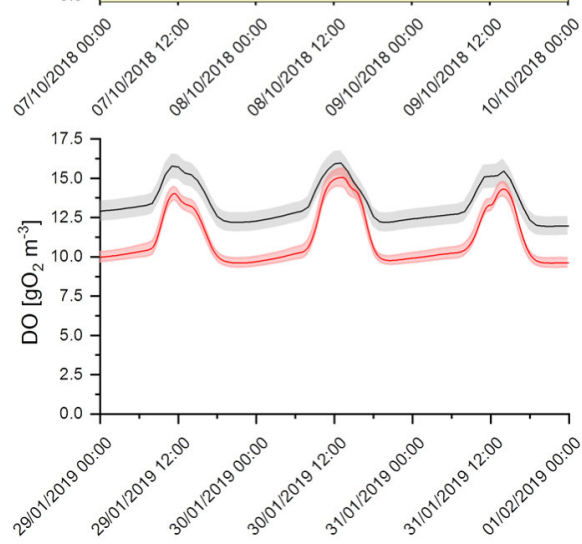

d)

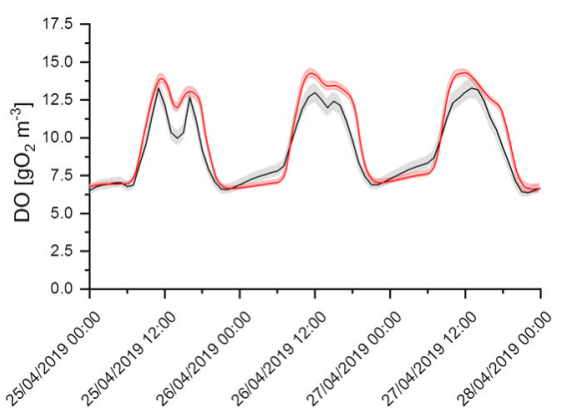

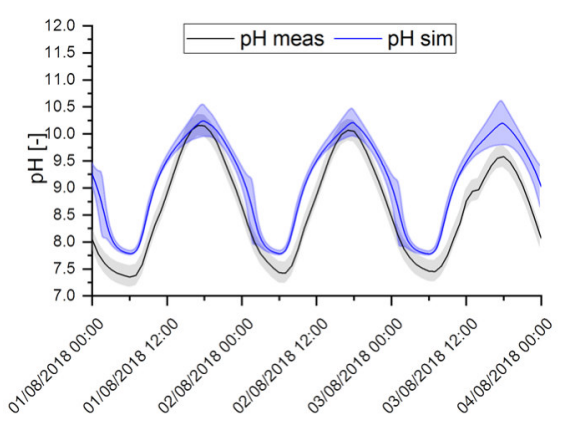
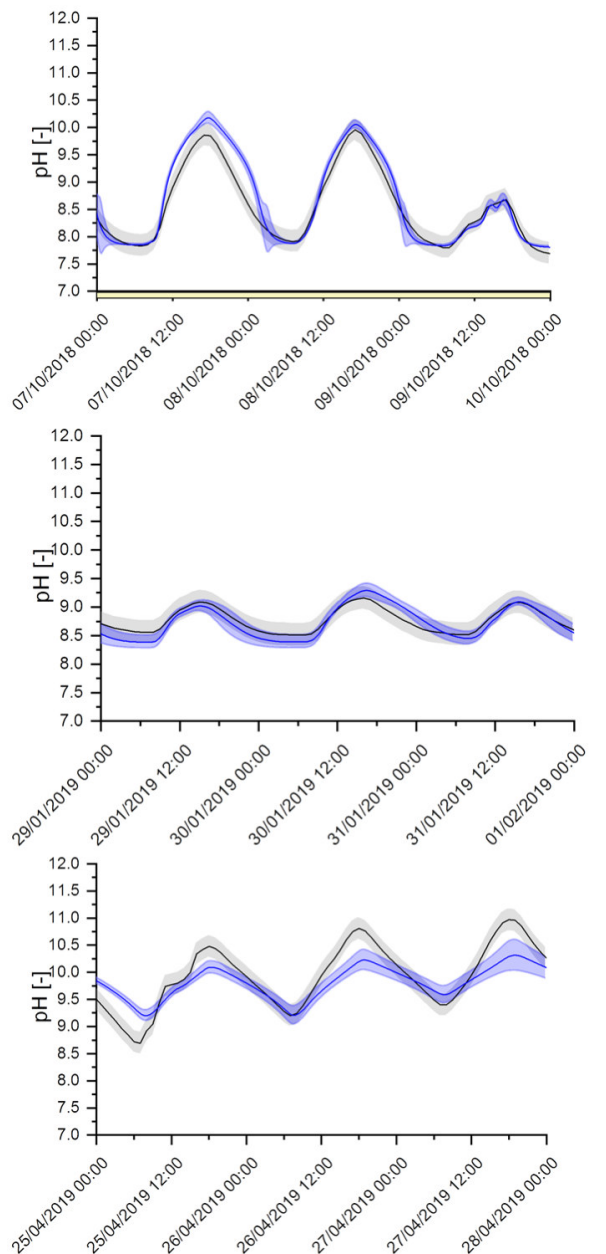

Figure 2. Nycthemeral dynamics for $\mathrm{DO}$ and $\mathrm{pH}$. Comparison of typical trends for measured (black), simulated $\mathrm{DO}$ (red) and simulated $\mathrm{pH}$ values (blue) during four seasons: summer (a), autumn (b), winter (c) and spring (d). Grey shaded areas represent the standard deviation of each experimental measurement. Red and blue shaded areas, for simulated DO and pH respectively, represent the $95 \%$ confidence intervals of model predictions. Yellow bars under the time-axis indicates that the data were used for parameter calibration.

\subsubsection{Long-term dynamics}

Once calibrated, the ALBA model was validated over a long-term experimental data set. Hereafter, its performances along with its ability to follow long term patterns, over a one-year period are discussed. It must be stressed that all the simulated long-term data shown in Figure 3 were obtained with the same parameter set used in the previously described nycthemeral $\mathrm{pH}$ and $\mathrm{DO}$ variation along the seasons. Satisfactory model performances can be observed for all data series including nitrogen compounds, biomass 
concentration, $\mathrm{COD}, \mathrm{pH}$ and $\mathrm{DO}$ values. In addition, the model performances were evaluated with the two model performance indices, TIC and MARE, on the entire period and separately for the different seasons (Table 4).

Accurately simulating the nitrogen compounds dynamics is challenging, since their concentrations are affected by almost all the processes taking place in the reactor. The best predictions for nitrogen compounds are obtained in spring and summer, while in autumn and winter simulations are less accurate (Figure $3 a$ and $3 \mathrm{~b}$ and Table 4). At the beginning of august 2018, a switch from partial to total nitrification was observed, and appropriately simulated, as shown by the decrease in nitrite concomitant with the increase in nitrate concentration (Figure 3b). It is worth remarking that the model prediction uncertainty becomes high around the switching time. It probably means that this switching time is highly sensitive to the parameter values and the initial conditions for biomass concentrations. Total nitrification becomes less efficient in autumn and winter, because of the decreasing temperature. This leads to a decrease in NOx concentrations and an increase in the ammonium concentration, also affected by the reduction in algae contribution to ammonium removal by assimilation. During winter, urea hydrolysis slows down remarkably, thus reducing the ammoniacal nitrogen availability in the system. Models for urea hydrolysis and their dependence on environmental parameters are missing in the literature. Therefore, the lower accuracy of the model during winter can be also attributed to a sub-optimal description of this poorly known process. It is worth noting that parameters related to denitrification and ammonia stripping were assumed from literature (see Table SI.5.1), therefore an insight in the dynamics of these processes would possibly improve the predictions of the nitrogen compounds.

The simulated algae biomass concentration, expressed in COD, is compared with the measurements derived from optical density at $680 \mathrm{~nm}$ in Figure 3c. The predicted algae concentration responded markedly to seasonal changes and fit well the measurements.

Model performances were assessed for TSS and soluble COD along all the year (Figure 3d). The low values of both the total TIC and the MARE criteria for TSS ( 0.13 and 0.26 respectively) highlight the model accuracy. The seasonal model predictions are slightly less accurate in spring and winter. This is possibly due to the influence of the start-up period (spring) which is affected by the selection of the initial conditions.

The soluble COD dynamics is generally well predicted by the model (Figure 3d). Spring and autumn 2018 are the most critical seasons in terms of goodness of fit. The same comments already reported as for TSS can be applied in the case of COD as well. 
527 The sensitivity analysis revealed how $\mathrm{pH}$ and dissolved oxygen dynamics play a central role by affecting the 528 overall balance among microbial populations. Thus, a correct prediction of these variables is of the utmost 529 importance for the accurate prediction of the overall system behaviour. Indeed, a generally good agreement 530 between model predictions and experimental values was obtained for both dissolved oxygen and $\mathrm{pH}$, as 531 show in Figure $3 e$ and Figure $3 f$. This is confirmed from the total TIC $(0.03$ and 0.11 for $\mathrm{pH}$ and DO, respectively) and MARE values (0.05 and 0.18 for $\mathrm{pH}$ and DO respectively). Looking at $\mathrm{pH}$ seasonal trends, 533 the model accuracy is satisfactory in all the periods. Also, for the dissolved oxygen, the overall model 534 efficiency criteria were satisfactory met, with a lower accuracy during winter.

535 It must be stressed that the MARE coefficients for nitrogen compounds and soluble COD are higher than the 536 ones reported for the other measurements (TSS, DO, pH), but these fit criteria are known to amplify small 537 model misfit when values are close to zero (Hauduc et al. 2015).

538 The model efficiently predicts most variable trends, demonstrating a sound prediction capability.

539 A better model fit could of course be obtained if a season-dependent set of parameters is chosen. 540

a)

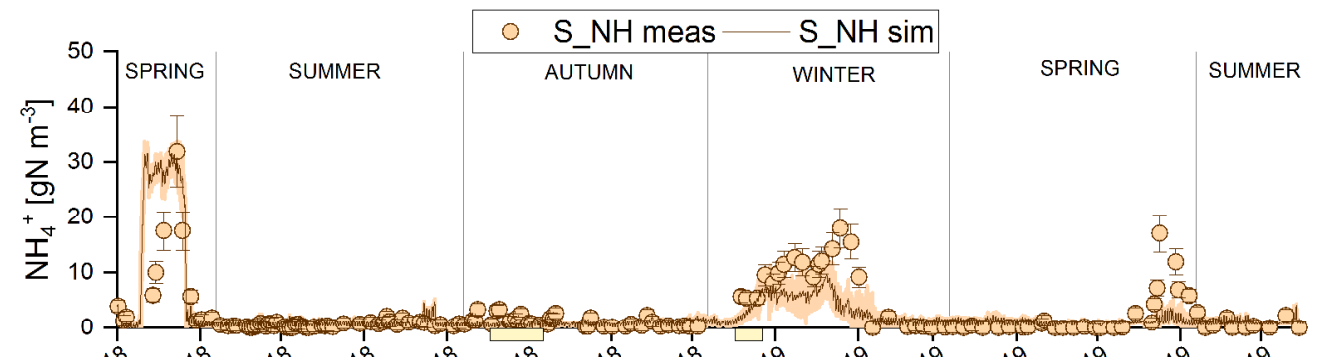

b)

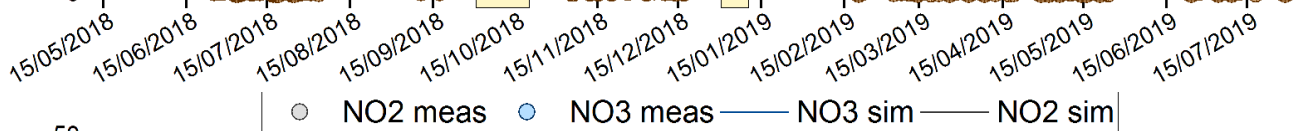

c)
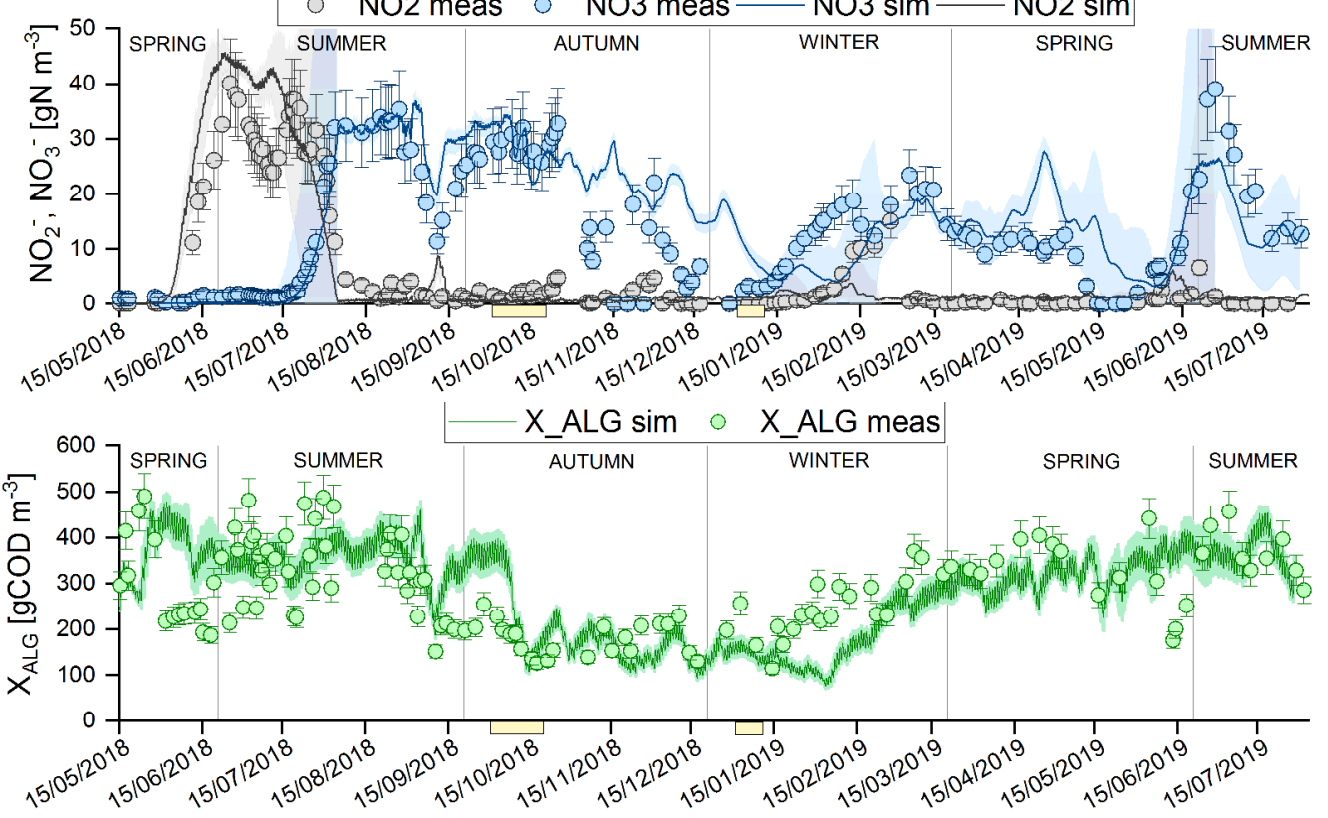
d)

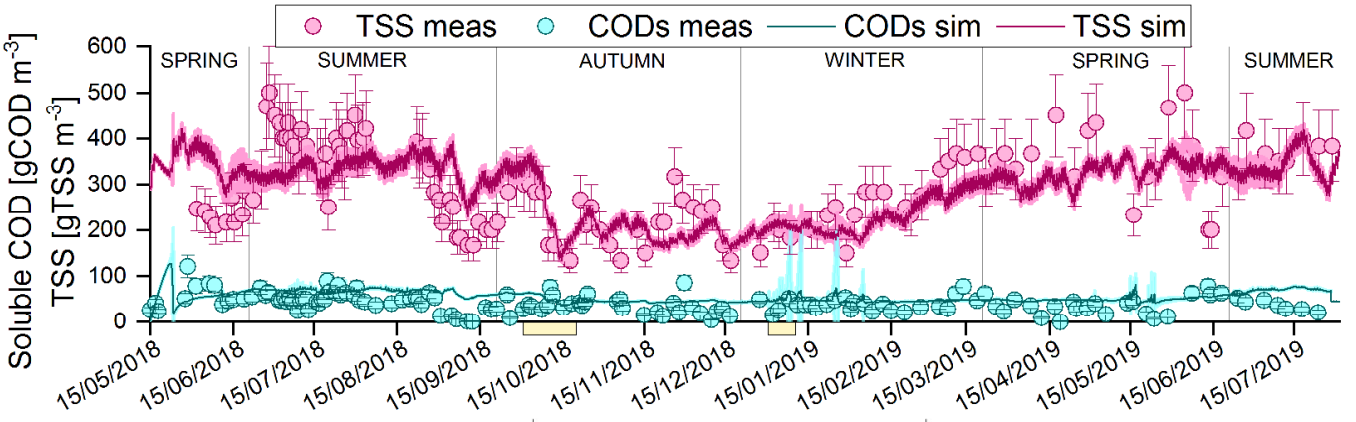

e)
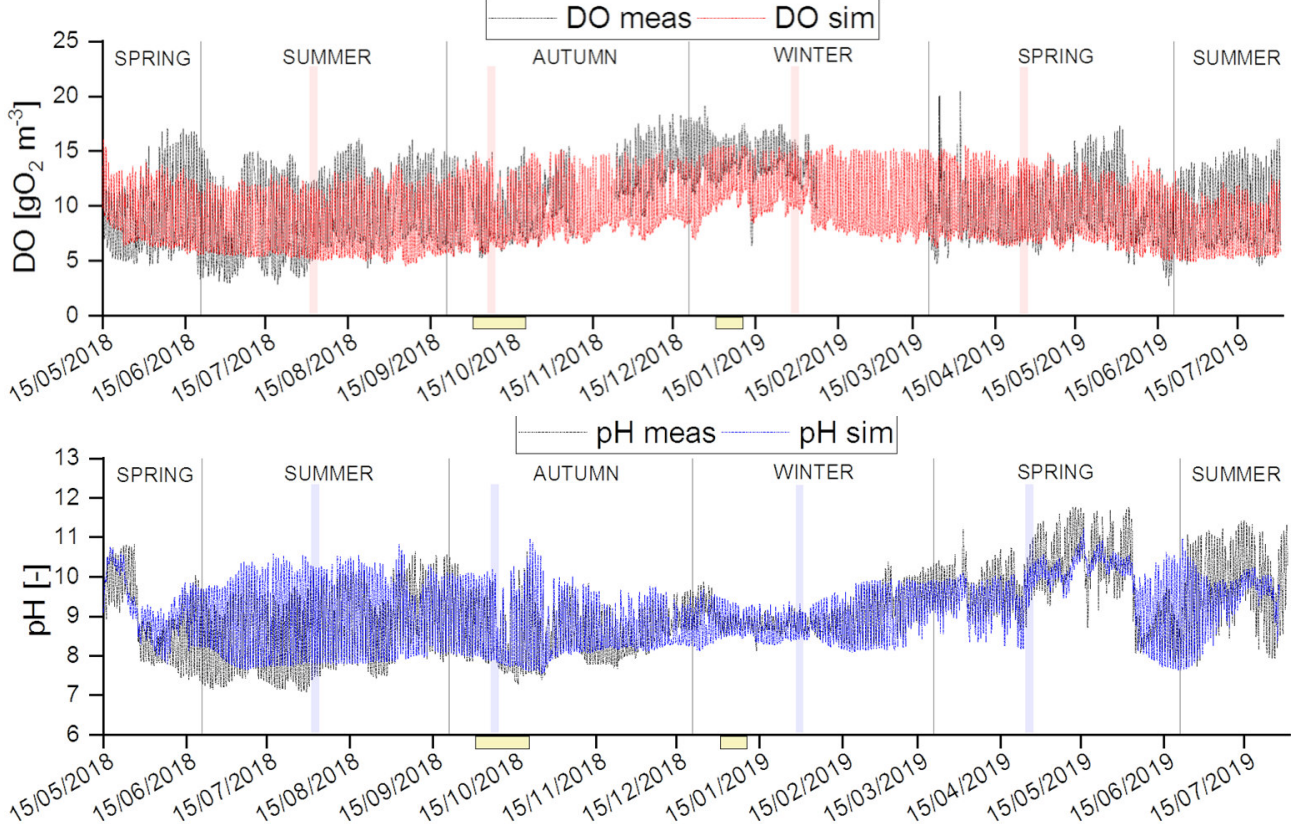

Figure 3. Long-term evolution of measured and simulated variables: ammonium (a), nitrite and nitrate (b), simulated algal biomass and measured optical density (c), Soluble organic compounds and Total Suspended Solids concentrations (d), dissolved oxygen (e), and pH (f). Error bars on experimental measurements represent their standard deviation. Shaded areas on model predictions represent the related $95 \%$ confidence intervals. Yellow bars under the time-axis indicates the calibration period. Coloured vertical bars in $\mathrm{pH}$ and DO graphs indicate the short-term dynamics represented on Figure 2.

Table 4. Model efficiency criteria evaluated for different variables in different seasonal conditions.

\begin{tabular}{|c|c|c|c|c|c|}
\hline \multicolumn{6}{|c|}{ Theil's Inequality Coefficient - TIC } \\
\hline & Total & Spring & Summer & Autumn & Winter \\
\hline $\mathrm{pH}$ & 0.03 & 0.03 & 0.04 & 0.03 & 0.02 \\
\hline $\mathrm{O} 2$ & 0.11 & 0.09 & 0.10 & 0.12 & 0.13 \\
\hline $\mathrm{N}-\mathrm{NH}_{4}{ }^{+}$ & 0.35 & 0.33 & 0.53 & 0.43 & 0.43 \\
\hline $\mathrm{N}-\mathrm{NO}_{2}^{-}$ & 0.18 & 0.26 & 0.16 & 0.67 & 0.69 \\
\hline $\mathrm{N}-\mathrm{NO}_{3}^{-}$ & 0.18 & 0.27 & 0.12 & 0.21 & 0.25 \\
\hline $\mathrm{X}_{\mathrm{ALG}}$ & 0.15 & 0.19 & 0.11 & 0.20 & 0.21 \\
\hline TSS & 0.13 & 0.17 & 0.13 & 0.13 & 0.14 \\
\hline CODs & 0.25 & 0.31 & 0.18 & 0.31 & 0.24 \\
\hline \multicolumn{6}{|c|}{ Mean Absolute Relative Error - MARE } \\
\hline $\mathrm{pH}$ & 0.05 & 0.05 & 0.07 & 0.04 & 0.03 \\
\hline $\mathrm{O} 2$ & 0.18 & 0.16 & 0.18 & 0.19 & 0.21 \\
\hline $\mathrm{N}-\mathrm{NH}_{4}{ }^{+}$ & 0.69 & 0.86 & 0.66 & 0.60 & 0.53 \\
\hline $\mathrm{N}-\mathrm{NO}_{2}^{-}$ & 0.52 & 0.63 & 0.42 & 0.76 & 0.66 \\
\hline $\mathrm{N}-\mathrm{NO}_{3}{ }^{-}$ & 0.50 & 0.64 & 0.22 & 1.02 & 0.37 \\
\hline $\mathrm{X}_{\mathrm{ALG}}$ & 0.31 & 0.41 & 0.23 & 0.38 & 0.31 \\
\hline TSS & 0.26 & 0.29 & 0.24 & 0.20 & 0.31 \\
\hline CODs & 0.51 & 0.42 & 0.44 & 0.84 & 0.26 \\
\hline
\end{tabular}




\section{Discussion}

\subsection{Decisive modelling choices}

Designing a model, especially for a complex outdoor biological process is the sum of many subtle and strategic choices (Mairet and Bernard, 2019). We detail hereafter the most determinant modelling choices, highlighting the main differences between ALBA and pre-existing algae-bacteria models.

Generally, nutrient limitation is computed as the product of all the functions affecting the process rates. This modelling choice was followed by most of the other algae-bacteria models, as RWQM1, BioAlgae2 and the Modified ASM3. However, multiplying limitation factors may lead to an undesired underestimation in quantifying the real biological activity, in presence of several limiting nutrients. For this reason, the Liebig's law was chosen to more accurately represent multi limitation situations (see Equation 4 and Table 3), since it describes that the most limiting nutrient drives the overall kinetics.

A similar strategy was adopted by the PHOBIA model, which however included the limiting and inhibiting factors for nutrient and light dependence in the minimum function argument.

Only few algae-bacteria models considered a dedicated sub-model to describe the dynamic evolution of $\mathrm{pH}$. So far, the most detailed $\mathrm{pH}$ model was found in the RWQM1, considering chemical equilibria for ammonium, bicarbonate, phosphates and calcium. It is worth pointing out that the $\mathrm{DO}$ and $\mathrm{pH}$ dynamics contained enough information to strongly constrain the most influent model parameters in the identification process. A correct prediction of $\mathrm{DO}$ and $\mathrm{pH}$ is therefore crucial to accurately simulate the overall system behaviour. Temperature turns out to play a direct (on solubility) and indirect (on activities) role on the dynamics. The specific choice for the functions representing the $\mathrm{pH}$ and oxygen impacts (also at high oxygen concentration) is thus important. In particular, it turns out that a distinct set of cardinal temperature and $\mathrm{pH}$ values is necessary to represent the dynamics of $A O B$ and NOB. Improvement in the $\mathrm{pH}$ model could still be made, accounting for the precipitation of several salts, especially at high $\mathrm{pH}$ values.

Rainfall and evaporation in outdoor conditions can have strong impact on the hydraulic balance of the raceway and must definitely be included in the modelling. Evaporation was relevant mostly in spring and summer, accounting on average for up to $15-25 \%$ of the influent flowrate.

Finally, the powerful calibration strategy associated with the ALBA model is also an important ingredient in the efficient model validation, from where the key role played by oxygen and $\mathrm{pH}$ dynamics clearly emerged. The seasonal sensitivity analysis provided the most sensitive parameters in every meteorological condition 
investigated. Therefore, through the calibration of this set of parameters over 30 days, it was possible to run the model and obtain good performances along all the period covered from the monitoring campaign (443 days, including the sub-optimal autumn-winter period).

\subsection{Unravelling the system behaviour under different oxygen transfer conditions}

The objective here was to use the model to unravel the role of oxygen transfer on biochemical and physical/chemical processes, in terms of oxygen, carbon and nitrogen transformation. To extend the validity of the analysis with a process scaling-up objective, two scenarios were simulated, imposing remarkably different mass transfer conditions.

The idea under the chosen values for the kıa was to simulate two extreme conditions: i) strong mixing and transfer rate conditions $\left(\mathrm{k}\left\llcorner a=34 \mathrm{~d}^{-1}\right)\right.$, reproducing the same settings as in the demonstrative scale raceway, equipped with a paddle wheel (linear velocity of $0.2 \mathrm{~m} \mathrm{~s}^{-1}$ ) and an additional mixing pump (flowrate $182 \mathrm{~m}^{3} \mathrm{~d}^{-}$ 1) ; ii) an alternative mixing system, using a propeller (Chiaramonti et al., 2013), that would result into appropriate mixing, but reduced gas exchanges with the atmosphere and eventually a lower mass-transfer coefficient $\left(\mathrm{kLa}=0.5 \mathrm{~d}^{-1}\right)$. In addition, these values are well comparable with the ones reported in specific literature studies for raceway channels and shallow ponds (Ginot and Hervé, 1994; Mendoza et al., 2013; Acien et al., 2017;).

The fate of carbon and nitrogen have then been computed to determine in which compartments they end up, and what is the fraction which is released (or absorbed) to (or from) the atmosphere. Results are shown in Figure $4 \mathrm{a}$ and Figure $4 \mathrm{~b}$.

Under strong aeration conditions, the inorganic carbon is converted into organic form, which is always higher in the effluent than in the influent, leaving the raceway mostly in the form of algal biomass. On the contrary, the inorganic carbon is reduced and converted into organic carbon present in the algal biomass. The loss of carbon by $\mathrm{CO}_{2}$ exchange towards atmosphere stays moderate. It is interesting to note that the net daily balance is even negative in spring and summer, meaning that the raceway is a net $\mathrm{CO}_{2}$ well. In contrast, during winter and autumn, it becomes a net $\mathrm{CO}_{2}$ emitter, though the emitted fraction remains very moderate. This demonstrates that algae-bacteria systems can contribute to $\mathrm{CO}_{2}$ capturing, while removing nutrients from wastewater, though the efficiency is season-dependent being chiefly influenced by photosynthesis. This contrasts with conventional activated sludge processes in which roughly half of the organic carbon will be eventually released in the atmosphere as $\mathrm{CO}_{2}$ (Moreno et al., 2017). The remaining fraction of organic carbon in the effluent is then significantly lower due to its oxidation by heterotrophic bacteria. In the 
algae/bacteria system, one can see that the organic carbon in the influent is significantly reduced and only partially converted into heterotrophic biomass. However, the organic carbon that is oxidised to $\mathrm{CO}_{2}$ by heterotrophic bacteria is further used in the photosynthetic process and found back in the algal biomass. Indeed, photosynthesis is a reduction process, where oxygen is produced and organic carbon is generated as a consequence of algal biomass production. This increase in TSS means a higher solid fraction to be removed in comparison to a standard aerobic treatment with activated sludge.

When simulating a case with a much lower gas/liquid exchange (propeller mixing), a reduction in algae productivity is observed. This is due to two main phenomena. The first one is the strong oxygen inhibition on algae growth during the light period, due to the high DO concentration (higher than $20 \mathrm{mg} \mathrm{L}^{-1}$ ) that accumulates in the reactor since the gas - liquid exchange is almost negligible. This is confirmed by the value of the mathematical expression describing oxygen dependence on algae growth and decay, which reduces the growth rate up to $40 \%$ and increases decay rates up to $60 \%$. While during spring and summer, the amount of organic carbon in the effluent is still slightly higher or equal to that in the influent, a slight loss is observed in autumn and winter, due to the reduced photosynthetic efficiency. By reducing the kLa, the conversion of the organic carbon by heterotrophic bacteria is almost unaffected since NOx can be used as an alternative electron acceptor during anoxic dark hours, as suggested by the nitrogen fate.

Focusing on the fate of nitrogen in the treatment process (Figure 4b), one can see that with high kıa, nitrifying bacteria play a major role in the nitrogen conversion efficiency. More specifically, during spring and summer, the largest fraction of nitrogen forms in the effluent are nitrite and nitrate, exceeding the fraction of nitrogen incorporated into the algal biomass. However, the fractions change during autumn and winter, when the organic nitrogen becomes one of the prevailing nitrogen forms leaving the system. This is due to the decreasing temperature, resulting in a reduced ammonification rate. The nitrogen removal efficiency (computed as the percentage of the nitrogen effectively removed from the wastewater, i.e. nitrogen gas plus the nitrogen in the biomass) is also affected during the cold seasons, being reduced from $42 \%$ during spring and summer down to $30 \%$ during winter.

When reducing the $\mathrm{k}\llcorner\mathrm{a}$, the main effect occurring in spring and summer is that denitrification processes become more efficient, as confirmed by the large amount of nitrogen gas in the output. During the winter season, the organic $\mathrm{N}$ leaving the system is also increased, together with some residual ammoniacal nitrogen. Nitrifying biomass activity is almost lost in winter, as a result of the combined effect of oxygen limitation during night and slower growth kinetics due to lower temperatures. In this scenario, the resulting nitrogen removal efficiency is higher than in the previous case, during spring, summer and autumn $(20 \%-$ 
$40 \%$ higher, on average). This is because the low kıa favoured denitrification, therefore a larger part of the influent nitrogen load is converted into nitrogen gas.

647 Conditions favouring the undesired ammonia stripping are those maximising the ammonia transfer i.e. high $\mathrm{k}\llcorner\mathrm{a}$ and high free ammonia level which happens in summer due to higher $\mathrm{pH}$ and temperature values. However, on average, a larger $\mathrm{NH}_{3}$ emission (though always below $8 \%$ of the nitrogen load) is computed for the low kıa scenario, due to the higher residual TAN.

The effect of kLa and seasonal variability on oxygen consumption and production rates was also evaluated in Figure 5a and Figure 5b. Oxygen production and consumption contributions are represented for the typical dark and light phases. For the sake of simplicity, only two seasons were considered and compared, i.e. summer and winter, given their larger difference in the ranges of the most relevant environmental parameters. The main oxygen uptake rate comes from the heterotrophic bacteria respiration, followed by the oxygen demand for nitrification and for algae respiration. This overall oxygen demand is fulfilled by algae photosynthesis during the light phase and by the gas/liquid transfer during the dark phase in both seasons.

a)

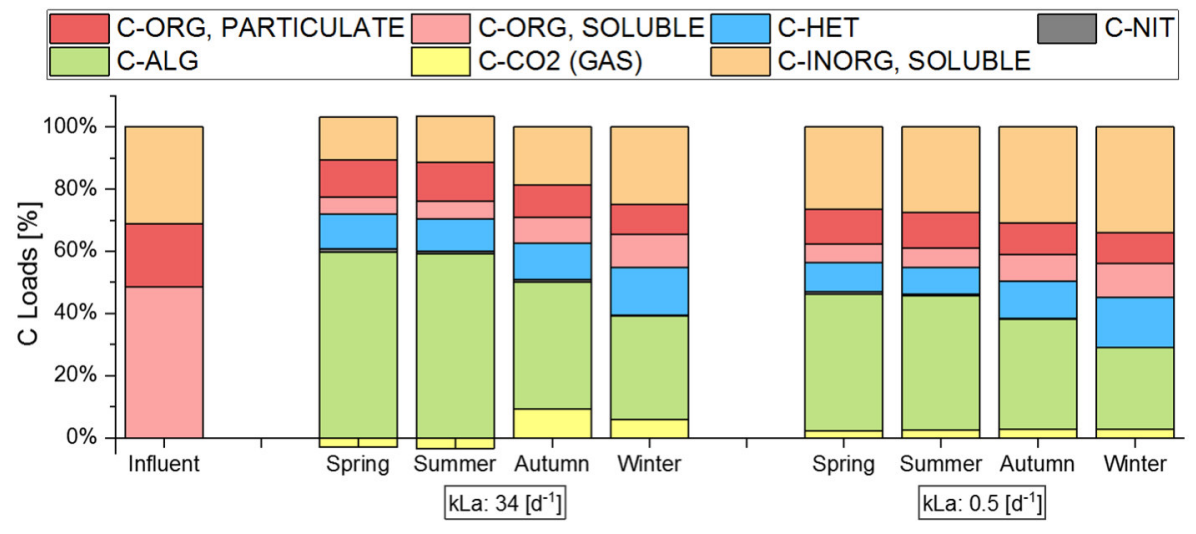

b)

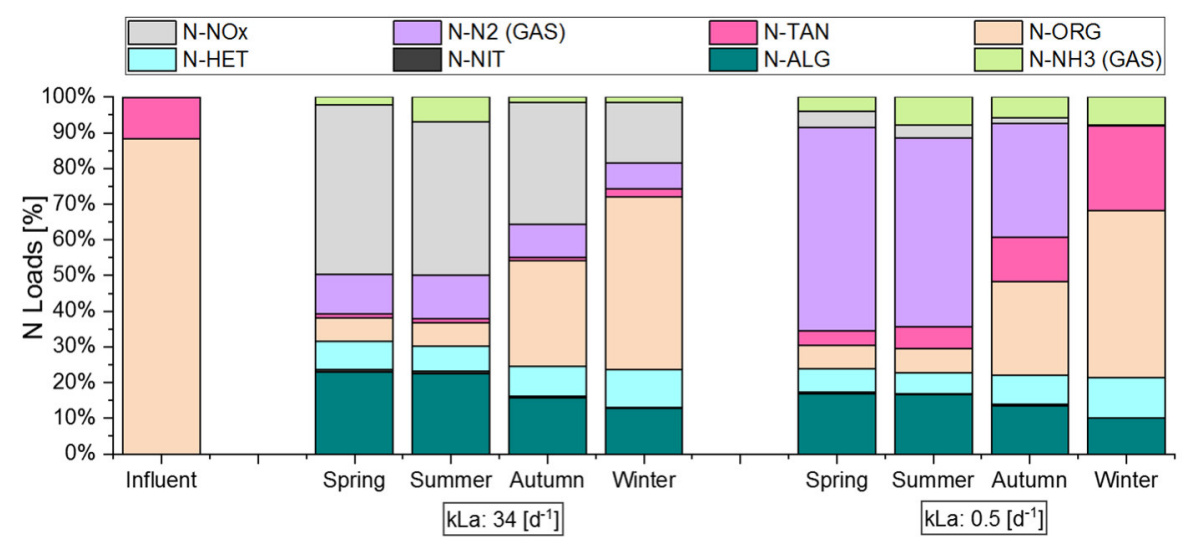

Figure 4. Apportioning of the influent and effluent carbon (4a) and nitrogen loads (4b) for different gas exchange rates (kLa: $34 \mathrm{~d}^{-1}$ and $0.5 \mathrm{~d}^{-1}$ ) and seasonal conditions (spring, summer, autumn and winter). In Fig. 4a, C-ORG (particulate) is the organic carbon in the $X_{S}$ and $X_{I}$ fractions; C-ORG (soluble) is the organic carbon in the $S_{S}$ and $S_{I}$ 
fractions; C-INORG (soluble) is the soluble inorganic carbon (modelled as $\mathrm{S}_{\mathrm{IC}}$ variable); C-NIT is the organic fraction in the nitrifying biomass (AOB and NOB); C-HET is the organic fraction in the heterotrophic bacterial biomass; CALG is the organic fraction in the algal biomass. In Figure $4 b, N-O R G$ is the organic nitrogen in $X_{s}, X_{I}, S_{s}, S_{I}$ fractions and as soluble organic nitrogen (modelled as $\mathrm{S}_{\mathrm{ND}}$ variable); N-NIT is the nitrogen in the nitrifying biomass ( $A O B$ and $N O B$ ); N-ALG is the nitrogen fraction in the algal biomass; N-HET is the nitrogen fraction in the heterotrophic bacterial biomass; $\mathrm{N}-\mathrm{NO}_{\mathrm{x}}$ is the nitrogen fraction in nitrite and nitrate; N-TAN is the nitrogen fraction in the total ammoniacal nitrogen (modelled as $\mathrm{S}_{\mathrm{NH}}$ variable). The computed fluxes of $\mathrm{NH}_{3}, \mathrm{CO}_{2}$ and $\mathrm{N}_{2}$ are gaseous, while all other are liquid fluxes.

In case of strong mixing, the gas/liquid exchange acts in opposite directions: during the light period, a large portion of the oxygen produced by algae is stripped (almost $40 \%$ of the overall consumption rate is associated to the gas/liquid transfer); during night, the oxygen transfer rate is the only oxygen-replenishing process making oxygen available to the algal and bacterial respiration. These data point out the importance of an adequate aeration regulation during both light and dark phases.

Very different results are obtained in a low kıa system (Figure 5b). During the light phase, microalgae are still providing enough oxygen to support respiration processes, but the extra oxygen production is not compensated by stripping, leading to an oxygen oversaturation which in turn inhibits algae growth. On the contrary, during night, oxygen concentration goes quickly to zero since the average oxygen solubilisation rate does not compensate for the oxygen consumption rate. During the night, denitrification is active, leading to nitrogen gas release to the atmosphere. A different scenario is achieved during winter time, when nitrogen remains mainly in the organic form, thus leading to limited nitrification and denitrification. Under these conditions, nitrifying bacteria activity seems to be unfavoured, especially because of the strong oxygen limitation during night. To overcome this issue, a possible strategy to be applied is to increase the HRT, to facilitate the retention of slow growing populations (AOB, NOB). This hypothesis was checked by running the model with an increased HRT (from 5 to 10 days) and confirmed by simulation results (data not shown).

a)

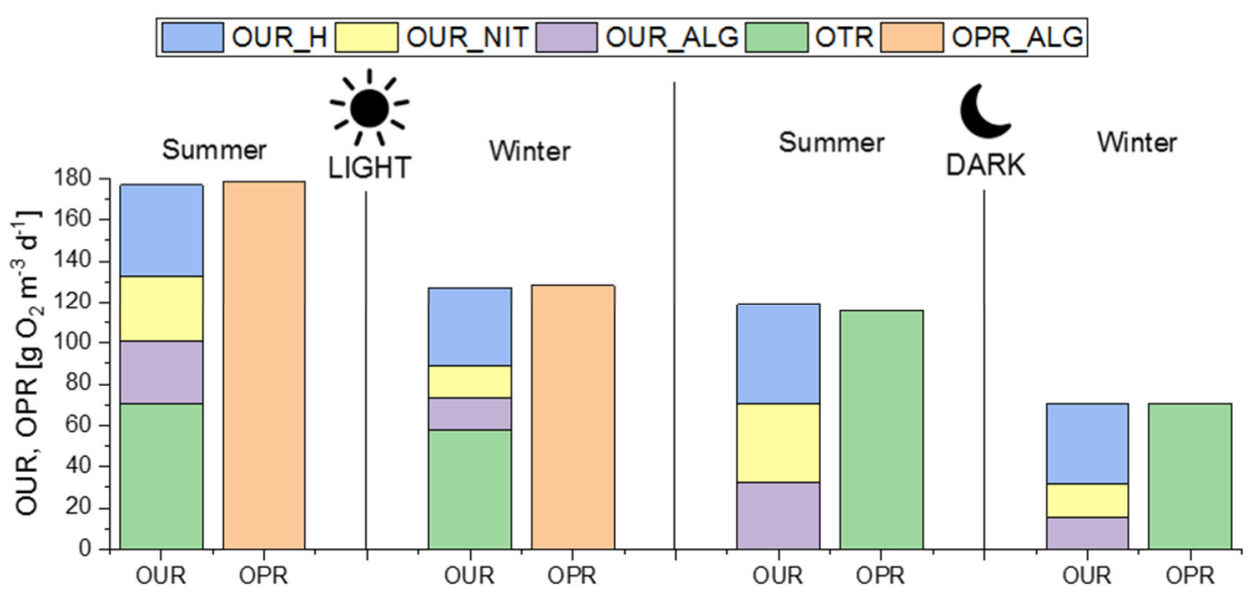




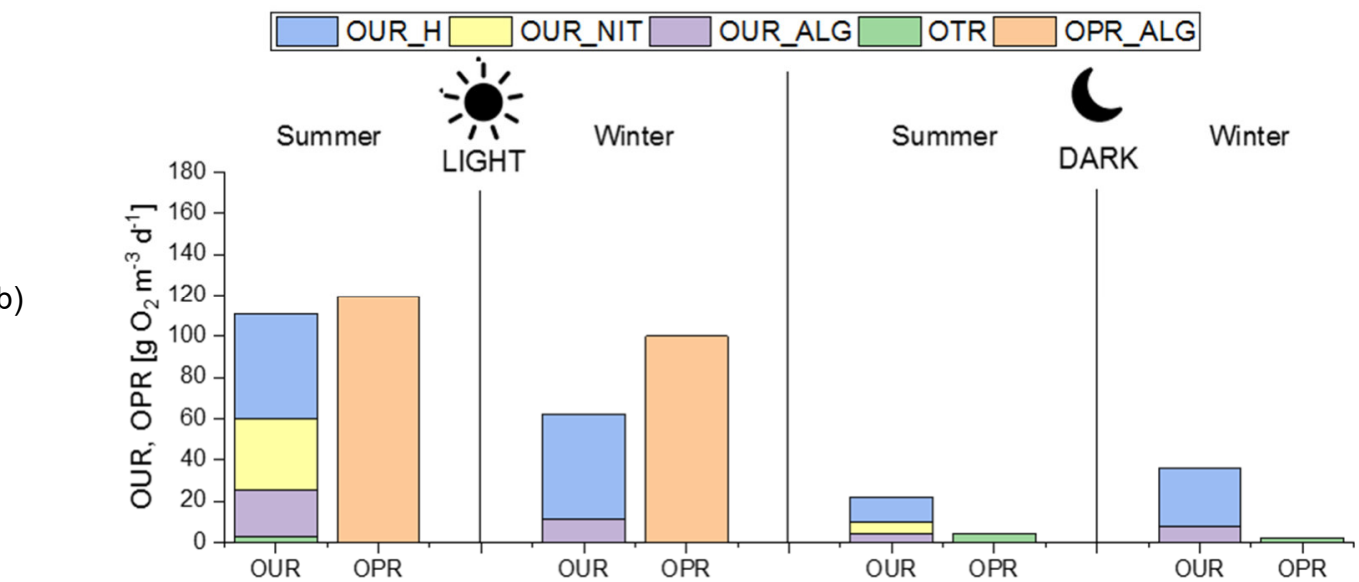

Figure 5. Day and night Oxygen Production Rates (OPR) and Oxygen Consumption Rates (OUR) scenarios, were evaluated for different seasons (winter, summer) and different kLa values: $34 \mathrm{~d}^{-1}(5 \mathrm{a})$ and $0.5 \mathrm{~d}^{-1}(5 \mathrm{~b})$. In Figure 5, OPR_ALG is the Oxygen Production Rate of algae; OUR_ALG, OUR_NIT and OUR_H are the Oxygen Consumption Rate of algae, nitrifiers and heterotrophs, respectively; OTR is the Oxygen Transfer Rate.

From the results discussed above, the gas/liquid exchange rate can be used as an operational parameter to regulate both algae growth (by limiting DO inhibition) and nutrient removal (by favouring anoxic denitrification or by compensating the oxygen demand during winter time). The feasibility to regulate the gas/liquid exchange according to the process needs, e.g. by adopting different paddlewheel velocity during light and dark phases and during seasons, could allow for an optimized operation of the HRABP.

For further investigations, it could be interesting to extend the model implementation in space, simulating stratified layers in the HRABP and analysing more in details the scenarios characterized by low mass transfer rates.

\section{Conclusions}

The ALBA model was designed balancing realism and model complexity. The design choices associated with a dedicated and powerful calibration strategy explain the remarkable model performance in simulating a pilot scale HRABP for 443 days, with both short term and long-term prediction capability. The noteworthy capability to correctly reproduce the experimental data trend along all the seasons with a unique set of parameters is a further confirmation of the strength of the model.

The ALBA model was built on existing models that were not validated on this timescale, being expanded to cover the long experimental monitoring campaign, which included seasonal dynamics. But it has some marked specificity, among other, the choice of the kinetics to describe multiple nutrients limitation, and the very detailed model for $\mathrm{pH}$ computation. This turns out to be the cornerstone of the model since an appropriate description of the dynamics of $\mathrm{pH}$ and dissolved oxygen is crucial for accurately reproduce the 
714 whole process dynamics. This also highlights the key role of oxygen and $\mathrm{CO}_{2}$ as an exchange currency

715 between the different actors of the ecosystem.

716 Scenarios analysis shows that, on average, the process is $\mathrm{CO}_{2}$ neutral, which means it does not emit $\mathrm{CO}_{2}$,

717 as compared to a standard activated sludge where half of the influent carbon will end up in the atmosphere.

718 As shown, further investigations about the net $\mathrm{CO}_{2}$ emissions from the HRABP can be easily computed with

719 the model, thus improving/supporting the existing LCA evaluation.

720 The ALBA model revealed that not only the acknowledged photo-oxygenation but also the gas/liquid transfer

721 plays a crucial role, directly affecting oxygen dynamics and indirectly defining microbial activities and $\mathrm{N}$ and

722 C fate. Indeed, results showed that a substantial reduction in the gas/liquid exchange negatively affects the

723 growth of both algal and bacterial biomass, consequently impacting nutrient removal efficiency. It is therefore

724 clear that a dedicated and flexible regulation of the gas transfer (eg., through modifying the paddle wheel

725 velocity) should be applied, allowing to appropriately balance the mixing, aeration and degassing effects.

726 Beyond offering a better understanding of this complex process, the ALBA model can now be used to

727 support the choice of optimal operational strategies, playing on various operational parameters such as HRT,

728 feeding pattern, water depth, mixing/aeration rate, and $\mathrm{pH}$ regulation. A model predictive control strategy

729 using this validated model can be now used, possibly accounting for meteorological forecasts.

730 
FC and EF wish to thank the Fondazione Cariplo (project: Polo delle Microalghe) for their financial support. OB benefited from the support of the ADEME Biomsa project.

All the authors want to thank the PHYCOVER project (ANR-14-CE04-0011) and the E-COST (European Cooperation in Science and Technology), action ES1408 - European network for algal-bioproducts (EUALGAE), for supporting the scientific collaboration.

\section{Author contribution statements}

GZ run the monitoring campaign and made the analytical analysis under the supervision of JPS. FC developed the model with feedback from EF, JPS and OB. FC implemented the model and developed the sensitivity and calibration procedure. FC wrote the manuscript with permanent feedback from EF, GZ, JPS and OB. EF obtained grants to support the study and supervised the work. In general, all authors provided critical feedback and helped shape the research, analysis and manuscript.

\section{References}

Acién, F.G., Molina, E., Reis, A., Torzillo, G., Zittelli, G.C., Sepúlveda, C. and Masojídek, J., 2017. Photobioreactors for the production of microalgae. In Microalgae-based biofuels and bioproducts (pp. 1-44). Woodhead Publishing.

APHA, 2017. Standard methods for the examination of water and wastewater, $23^{\text {rd }}$ ed. American Public Health Association, Washington DC, USA.

Arashiro, L.T., Rada-Ariza, A.M., Wang, M., Van Der Steen, P. and Ergas, S.J., 2017. Modelling shortcut nitrogen removal from wastewater using an algal-bacterial consortium. Water Science and Technology, 75(4), pp.782-792.

Arashiro, L.T., Montero, N., Ferrer, I., Acién, F.G., Gómez, C. and Garfí, M., 2018. Life cycle assessment of high rate algal ponds for wastewater treatment and resource recovery. Science of the total environment, 622, 1118-1130.

Arias, D.M., García, J. and Uggetti, E., 2019. Production of polymers by cyanobacteria grown in wastewater: Current status, challenges and future perspectives. New biotechnology.

Batstone, D. J., Keller, J., Angelidaki, I., Kalyuzhnyi, S. V., Pavlostathis, S. G., Rozzi, A., ... \& Vavilin, V. A., 2002. The IWA anaerobic digestion model no 1 (ADM1). Water Science and technology, 45(10), 65-73.

Béchet, Q., Shilton, A., Park, J.B., Craggs, R.J. and Guieysse, B., 2011. Universal temperature model for shallow algal ponds provides improved accuracy. Environmental science \& technology, 45(8), 3702-3709.

Béchet, Q., Sialve, B., Steyer, J.P., Shilton, A. and Guieysse, B., 2018. Comparative assessment of evaporation models in algal ponds. Algal Research, 35, 283-291.

Bernard, O., \& Rémond, B., 2012. Validation of a simple model accounting for light and temperature effect on microalgal growth. Bioresource technology, 123, 520-527.

Bougaran, G., Bernard, O. and Sciandra, A., 2010. Modeling continuous cultures of microalgae colimited by nitrogen and phosphorus. Journal of theoretical biology, 265(3), pp.443-454.

Cai, T., Park, S.Y. and Li, Y., 2013. Nutrient recovery from wastewater streams by microalgae: status and prospects. Renewable and Sustainable Energy Reviews, 19, 360-369. 

538

Caia, M., Bernard, O. and Béchet, Q., 2018. Optimizing CO2 transfer in algal open ponds. Algal research, 35, 530-

Casagli F., Zuccaro G., Pizzera A., Steyer J.P., and Ficara E., 2019 'A comprehensive model to optimize microalgae-bacteria wastewater treatment in raceway ponds', in 2nd IWA Conference on Algal Technologies for Wastewater Treatment and Resource Recovery - 1-2 July IWAlgae 2019, 255-256.

Chew, K.W., Yap, J.Y., Show, P.L., Suan, N.H., Juan, J.C., Ling, T.C., Lee, D.J. and Chang, J.S., 2017. Microalgae biorefinery: high value products perspectives. Bioresource technology, 229, 53-62.

Chiaramonti, D. et al., "Review of energy balance in raceway ponds for microalgae cultivation: Re-thinking a traditional system is possible," Appl. Energy, vol. 102, pp. 101-111, Feb. 2013, doi: 10.1016/j.apenergy.2012.07.040.

De Baar, H.J.W., 1994. von Liebig's law of the minimum and plankton ecology (1899-1991). Progress in oceanography, 33(4), 347-386.

Decostere, B., De Craene, J., Van Hoey, S., Vervaeren, H., Nopens, I., \& Van Hulle, S. W., 2016. Validation of a microalgal growth model accounting with inorganic carbon and nutrient kinetics for wastewater treatment. Chemical Engineering Journal, 285, 189-197.

Di Veroli, G. Y., Fornari, C., Goldlust, I., Mills, G., Koh, S. B., Bramhall, J. L., ... Jodrell, D. I.. 2015. An automated fitting procedure and software for dose-response curves with multiphasic features. Nature Scientific Reports 5, 14701, 111.

Dolman, A.M. and Wiedner, C., 2015. Predicting phytoplankton biomass and estimating critical N: $P$ ratios with piecewise models that conform to Liebig's law of the minimum. Freshwater Biology, 60(4), pp.686-697.

Ginot, V. and Hervé, J.C., 1994. Estimating the parameters of dissolved oxygen dynamics in shallow ponds. Ecological modelling, 73(3-4), 69-187.

Grobbelaar, J. U., 2004. Algal nutrition. Mineral Nutrition, in A.Richmond, Handbook of microalgal culture: Biotechnology and applied phycology, Wiley-Blackwell: 97-115.

Hauduc, H., Neumann, M.B., Muschalla, D., Gamerith, V., Gillot, S. and Vanrolleghem, P.A., 2015. Efficiency criteria for environmental model quality assessment: A review and its application to wastewater treatment. Environmental modelling \& software, 68, 196-204.

Henze, M., Gujer, W., Mino, T. and van Loosdrecht, M.C., 2000. Activated sludge models ASM1, ASM2, ASM2d and ASM3. IWA publishing, London, UK.

Hreiz, R., Sialve, B., Morchain, J., Escudié, R., Steyer, J.P. and Guiraud, P., 2014. Experimental and numerical investigation of hydrodynamics in raceway reactors used for algaculture. Chemical Engineering Journal, 250, pp.230239.

lacopozzi, I., Innocenti, V., Marsili-Libelli, S., \& Giusti, E., 2007. A modified Activated Sludge Model No. 3 (ASM3) with two-step nitrification-denitrification. Environmental Modelling \& Software, 22(6), 847-861.

Ippoliti, D., Gómez, C., del Mar Morales-Amaral, M., Pistocchi, R., Fernández-Sevilla, J.M. and Acién, F.G., 2016. Modeling of photosynthesis and respiration rate for Isochrysis galbana (T-Iso) and its influence on the production of this strain. Bioresource technology, 203, 71-79.

Lee, E., Jalalizadeh, M. and Zhang, Q., 2015. Growth kinetic models for microalgae cultivation: a review. Algal research, 12, 497-512.

Mairet, F. et Bernard, O., 2019. Twelve quick tips for designing sound dynamical models for bioprocesses. PLoS computational biology, 15(8), e1007222.

Martínez, C., Mairet, F., \& Bernard, O., 2018. Theory of turbid microalgae cultures. Journal of theoretical biology, 456, $190-200$.

Mendoza, J.L., Granados, M.R., De Godos, I., Acién, F.G., Molina, E., Heaven, S. and Banks, C.J., 2013. Oxygen transfer and evolution in microalgal culture in open raceways. Bioresource technology, 137, 188-195. 
Moreno, R., Correia, M. and Martins, F., 2017. Energy and environmental performance of wastewater treatment plants: A statistical approach. Energy Procedia, 136, 296-301.

Muñoz, R. and Guieysse, B., 2006. Algal-bacterial processes for the treatment of hazardous contaminants: a review. Water research, 40(15), 2799-2815.

Nopens, I., Capalozza, C. and Vanrolleghem, P.A., 2001. Stability analysis of a synthetic municipal wastewater. Department of Applied Mathematics Biometrics and Process Control, University of Gent, Belgium.

Oswald, W.J., Gotaas, H.B., Golueke, C.G., Kellen, W.R., Gloyna, E.F. and Hermann, E.R., 1957. Algae in waste treatment [with discussion]. Sewage and Industrial Wastes, 29(4), 437-457.

Peng, L., Lan, C.Q. and Zhang, Z., 2013. Evolution, detrimental effects, and removal of oxygen in microalga cultures: a review. Environmental Progress \& Sustainable Energy, 32(4), 982-988.

Petzold, L.R., 1982. Description of DASSL: a differential/algebraic system solver (No. SAND-82-8637; CONF820810-21). Sandia National Labs., Livermore, CA (USA).

Pizzera, A., Scaglione, D., Bellucci, M., Marazzi, F., Mezzanotte, V., Parati, K. and Ficara, E., 2019. Digestate treatment with algae-bacteria consortia: A field pilot-scale experimentation in a sub-optimal climate area. Bioresource technology, 274, 232-243.

Rada-Ariza, A., 2018. Photo-Activated Sludge: a novel algal-bacterial biotreatment for nitrogen removal from wastewater. Ph.D Thesis, Wageningen University, CRC Press/Balkema, Leiden.

Reichert, P., 1994. AQUASIM-A tool for simulation and data analysis of aquatic systems. Water Science and Technology, 30(2), 21-30.

Reichert, P., Borchardt, D., Henze, M., Rauch, W., Shanahan, P., Somlyódy, L. and Vanrolleghem, P., 2001. River water quality model no. 1 (RWQM1): II. Biochemical process equations. Water Science and Technology, 43(5), 11-30.

Rossi, S., Casagli, F., Mantovani, M., Mezzanotte, V. and Ficara, E., 2020. Selection of photosynthesis and respiration models to assess the effect of environmental conditions on mixed microalgae consortia grown on wastewater. Bioresource Technology, 305, 122995.

Rosso, L., Lobry, J.R. and Flandrois, J.P., 1993. An unexpected correlation between cardinal temperatures of microbial growth highlighted by a new model. Journal of Theoretical Biology, 162(4), 447-463.

Rosso, L., Lobry, J.R., Bajard, S. and Flandrois, J.P., 1995. Convenient model to describe the combined effects of temperature and $\mathrm{pH}$ on microbial growth. Appl. Environ. Microbiol., 61(2), 610-616.

Shoener, B.D., Schramm, S.M., Béline, F., Bernard, O., Martínez, C., Plósz, B.G., Snowling, S., Steyer, J.P., Valverde-Pérez, B., Wágner, D. and Guest, J.S., 2019. Microalgae and cyanobacteria modeling in water resource recovery facilities: A critical review. Water research $\mathrm{X}, 2,100024$.

Solimeno, A., Gómez-Serrano, C., \& Acién, F. G., 2019. BIO_ALGAE 2: improved model of microalgae and bacteria consortia for wastewater treatment. Environmental Science and Pollution Research, 26(25), 25855-25868.

Solimeno, A., Parker, L., Lundquist, T. and García, J., 2017. Integral microalgae-bacteria model (BIO_ALGAE): Application to wastewater high rate algal ponds. Science of the total environment, 601, pp.646-657.

Solimeno, A., Samsó, R., Uggetti, E., Sialve, B., Steyer, J.P., Gabarró, A. and García, J., 2015. New mechanistic model to simulate microalgae growth. Algal research, 12, 350-358.

Turon, V., Baroukh, C., Trably, E., Latrille, E., Fouilland, E. and Steyer, J.P., 2015. Use of fermentative metabolites for heterotrophic microalgae growth: Yields and kinetics. Bioresource technology, 175, 342-349.

Uggetti, E., Sialve, B., Trably, E. and Steyer, J.P., 2014. Integrating microalgae production with anaerobic digestion: a biorefinery approach. Biofuels, Bioproducts and Biorefining, 8(4), 516-529. 
Van Loosdrecht, M.C.M., Lopez-Vazquez, C.M., Meijer, S.C.F., Hooijmans, C.M. and Brdjanovic, D., 2015. Twentyfive years of ASM1: past, present and future of wastewater treatment modelling. Journal of Hydroinformatics, 17(5), 697718.

858 Wolf, G., Picioreanu, C., \& van Loosdrecht, M. C., 2007. Kinetic modeling of phototrophic biofilms: The PHOBIA model. 859 Biotechnology and bioengineering, 97(5), 1064-1079. 
865

866 Francesca Casaglia, Gaetano Zuccaro $^{b}$, Olivier Bernard ${ }^{c}$, Jean-Philippe Steyer ${ }^{b}$, Elena Ficara ${ }^{a}$

867

868

869

870

871

872

873

ALBA: a comprehensive growth model to optimize algae-bacteria wastewater treatment in raceway ponds

\section{Supporting Informations}

\author{
a: Politecnico di Milano, Dip. di Ingegneria Civile e Ambientale (DICA), Piazza L. da Vinci, 32, 20133 Milan, Italy \\ b: INRAE, Univ Montpellier, LBE, 102 Avenue des étangs, Narbonne, France \\ c: Biocore, Univ Cote d'Azur, Inria, Sophia-Antipolis, France \\ *-Corresponding author: elena.ficara@polimi.it
}



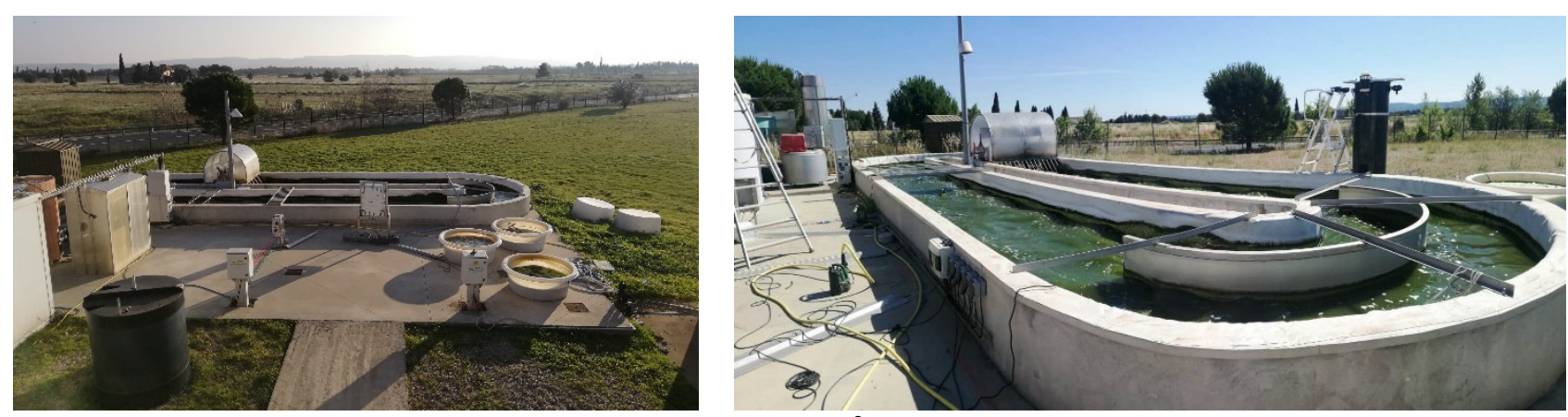

Figure SI.1.1. demonstrative scale raceway $\left(17 \mathrm{~m}^{3}\right)$, located in Narbonne, France (INRAE).

877

878

879

880

881

\section{SI 1.1 Estimation of the light extinction coefficient}

The PAR was measured at different depths of the reactor. The probe was maintained at six points along depth $(2,5,8,12,16$ and $20 \mathrm{~cm})$, registering the data for half an hour. The TSS concentration in the algal suspension was measured for each test. The Beer-Lambert equation was used to describe light extinction with the depth $z[\mathrm{~m}]$ :

$$
\ln \left(\frac{I(z)}{I(0)}\right)=-\varepsilon \cdot c \cdot z
$$

where $\mathrm{I}(\mathrm{z})$ is the PAR value $\left[\mu \mathrm{mol} \mathrm{m} \mathrm{m}^{-2} \mathrm{~s}^{-1}\right.$ ] measured at depth $z[\mathrm{~m}] ; \mathrm{I}(0)$ is the PAR value [ $\mu \mathrm{mol} \mathrm{m}^{-2} \mathrm{~s}^{-1}$ ] measured at the pond surface $(z=0) ; c$ is the algal suspension TSS $\left[\mathrm{g} \mathrm{m}^{-3}\right] ; \varepsilon$ is the light extinction coefficient $\left[\mathrm{m}^{2} \mathrm{~g}^{-1}\right]$. The logarithm values of light data were evaluated for the different reactor depths $(0-20 \mathrm{~cm})$ during each test. The light extinction coefficient and its confidence interval were then estimated through linear regression (fitlm and confCI functions in MATLAB R2019b). Results are reported in table SI.1.1.

Table SI.1.1: TSS measurements and estimated light extinction coefficients with corresponding 95\% confidence intervals for each test

\begin{tabular}{|c|c|c|c|}
\hline \multirow{2}{*}{ Test date } & TSS & $\varepsilon$ & Confidence interval on $\varepsilon$ \\
\hline & [gTSS m$~ m^{-3}$ ] & {$\left[\mathrm{m}^{2}\right.$ gTSS $\left.^{-1}\right]$} & {$\left[\mathrm{m}^{2} \mathrm{gTSS}^{-1}\right]$} \\
\hline 07/09/2018 & 183 & 0.113 & {$[0.094,0.131]$} \\
\hline $27 / 09 / 2018$ & 300 & 0.095 & {$[0.072,0.119]$} \\
\hline 04/10/2018 & 292 & 0.083 & {$[0.062,0.104]$} \\
\hline $24 / 10 / 2018$ & 212 & 0.112 & {$[0.082,0.143]$} \\
\hline 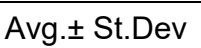 & $247 \pm 58$ & $0.101 \pm 0.014$ & - \\
\hline
\end{tabular}




\section{SI 1.2 Correlation between absorption measurements at $680 \mathrm{~nm}$ and algal biomass}

903

Additional tests were performed to determine the correlation factor between the optical density measured at $680 \mathrm{~nm}$ (O.D.680 nm) (Helios Epsilon, Thermo Scientific) and the algal biomass (X alg meas, gCOD.m ${ }^{-3}$ ). Different batch with a volume of $500 \mathrm{~mL}$, containing Tris-Acetate-Phosphate Medium (TAP) without organic carbon source and $\mathrm{NaHCO}_{3}$ concentrations equal to $40 \mathrm{mM}$ and $60 \mathrm{mM}$ (Merck KGaA, Darmstadt, Germany) were inoculated with the biomass from the raceway mainly composed by Chlorella sp. The algal biomass (gCOD.m-3) was derived from dry weight measurements (TSS) using the conversion factor $1.57 \mathrm{gCOD}$ gALG-1. $^{-1}$

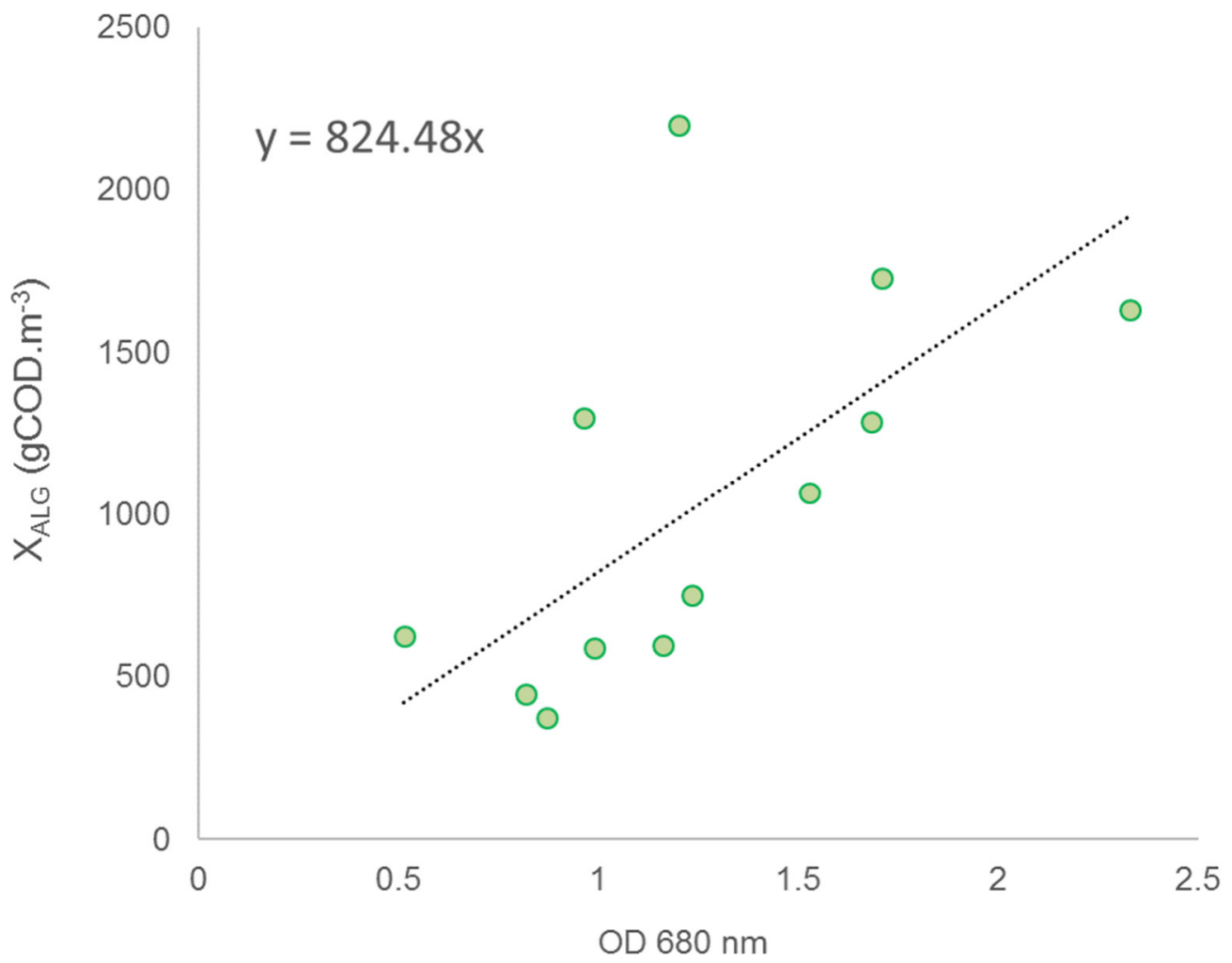

Figure SI.1.2: Correlation between optical density at $680 \mathrm{~nm}$ and algal biomass $\left(\mathrm{gCOD} \mathrm{m} \mathrm{m}^{-3}\right)$ 
907 The way standard deviation is estimated from the variation coefficient is presented in Table SI.2.1. For 908 measurements lower than a threshold $\varpi$, the standard deviation is assumed to be constant.

Table SI.2.1: measurement uncertainty modelling: standard deviation as a function of mean value $\omega$.

Threshold Standard deviation

\begin{tabular}{ccccc} 
Measurement & Unit & $\varpi$ & $\omega<\varpi$ & $\varpi<\omega$ \\
\hline $\mathrm{DO}$ & $\mathrm{mgO}_{2 . L^{-1}}$ & - & - & $5 \% \varpi$ \\
\hline $\mathrm{pH}$ & - & - & - & $2 \% \varpi$ \\
\hline $\mathrm{sCOD}$ & $\mathrm{mgCOD} \mathrm{L}$ & 5 & 1 & $20 \% \varpi$ \\
$\mathrm{COD}_{A L G}$ & $\mathrm{mgCOD} \mathrm{L}-1$ & 5 & 1 & $20 \% \varpi$ \\
$\mathrm{P}_{-} \mathrm{PO}_{4}{ }^{3-}$ & $\mathrm{mgP} \mathrm{L}$ & 5 & 1 & $20 \% \varpi$ \\
$\mathrm{N}-\mathrm{NH}_{4}$ & $\mathrm{mgN} \mathrm{L}^{-1}$ & 5 & 1 & $20 \% \varpi$ \\
$\mathrm{N}-\mathrm{NO}_{3}-$ & $\mathrm{mgN} \mathrm{L}^{-1}$ & 5 & 1 & $20 \% \varpi$ \\
$\mathrm{N}-\mathrm{NO}_{2}$ & $\mathrm{mgN} \mathrm{L}^{-1}$ & 5 & 1 & $20 \% \varpi$ \\
\hline
\end{tabular}


913 Table SI.3.1: ALBA model stoichiometric matrix

\begin{tabular}{|c|c|c|c|c|c|c|c|c|c|c|c|c|c|c|c|c|c|c|}
\hline $\begin{array}{l}\text { component } \\
\mathrm{j} \rightarrow \\
\text { process } \mathrm{i} \downarrow\end{array}$ & & $\begin{array}{c}\mathrm{X}_{\mathrm{ALG}} \\
\mathrm{gCOD} \\
\mathrm{m}^{-3}\end{array}$ & $\begin{array}{c}\mathrm{X}_{\mathrm{AOB}} \\
\mathrm{gCOD} \\
\mathrm{m}^{-3}\end{array}$ & $\begin{array}{c}\mathrm{X}_{\mathrm{NOB}} \\
\mathrm{gCOD} \\
\mathrm{m}^{-3}\end{array}$ & $\underset{\mathrm{m}^{-3}}{\mathrm{gCOD}_{H}}$ & $\begin{array}{c}\mathrm{X}_{\mathrm{S}} \\
\mathrm{gCOD} \\
\mathrm{m}^{-3}\end{array}$ & $\begin{array}{c}\mathrm{X}_{1} \\
\mathrm{gCOD} \\
\mathrm{m}^{-3}\end{array}$ & 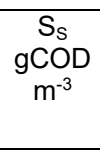 & $\begin{array}{c}\mathrm{S}_{\mathrm{I}} \\
\mathrm{gCOD} \\
\mathrm{m}^{-3}\end{array}$ & $\begin{array}{c}\mathrm{S}_{\mathrm{IC}} \\
\mathrm{gCm}^{-3}\end{array}$ & $\begin{array}{c}\mathrm{S}_{\mathrm{ND}} \\
\mathrm{gNm}_{3}^{-}\end{array}$ & $\begin{array}{c}\mathrm{S}_{\mathrm{NH}} \\
\mathrm{gNm}_{3}^{-}\end{array}$ & $\begin{array}{c}\mathrm{S}_{\mathrm{NO2}} \\
\mathrm{gNm}^{-}\end{array}$ & $\begin{array}{c}\mathrm{S}_{\mathrm{NO3}} \\
\mathrm{gNm}_{3}^{-}\end{array}$ & $\begin{array}{c}\mathrm{S}_{\mathrm{N} 2} \\
\mathrm{gNm}^{-3}\end{array}$ & $\begin{array}{l}\mathrm{S}_{\mathrm{PO} 4} \\
\mathrm{gPm}_{3}^{-}\end{array}$ & $\begin{array}{c}\mathrm{S}_{\mathrm{O} 2} \\
\mathrm{gO}_{3} \mathrm{~m}^{-}\end{array}$ & $\begin{array}{l}\mathrm{S}_{\mathrm{H} 2 \mathrm{O}} \\
\mathrm{gHm} \\
-3\end{array}$ \\
\hline \multicolumn{19}{|l|}{ Algae } \\
\hline 1 & $\begin{array}{l}\text { phototrophic } \\
\text { growth on } \\
\mathrm{NH}_{4}^{+}\end{array}$ & 1 & & & & & & & & $\alpha_{1,9}$ & & $\alpha_{1,11}$ & & & & $\alpha_{1,15}$ & 1 & $\alpha_{1,17}$ \\
\hline 2 & phototrophic & & & & & & & & & $\alpha_{2,9}$ & & & & & & $\alpha_{2,15}$ & & $\alpha_{2,17}$ \\
\hline & $\begin{array}{l}\text { growth on } \\
\mathrm{NO}_{3}^{-}\end{array}$ & 1 & & & & & & & & & & & & $\alpha_{2,13}$ & & & 1 & \\
\hline 3 & $\begin{array}{l}\text { aerobic } \\
\text { respiration }\end{array}$ & -1 & & & & & & & & $\alpha_{3,9}$ & & $\alpha_{3,11}$ & & & & $\alpha_{3,15}$ & -1 & $\alpha_{3,17}$ \\
\hline 4 & Decay & -1 & & & & $\alpha_{4,5}$ & $\alpha_{4,6}$ & & & $\alpha_{4,9}$ & & $\alpha_{4,11}$ & & & & $\alpha_{4,15}$ & & \\
\hline \multirow{2}{*}{\multicolumn{19}{|c|}{ Heterotrophic bacteria }} \\
\hline & & & & & & & & & & & & & & & & & & \\
\hline 5 & $\begin{array}{l}\text { growth on } \\
\mathrm{NH}_{4}^{+}\end{array}$ & & & & 1 & & & $\alpha_{5,7}$ & & $\alpha_{5,9}$ & & $\alpha_{5,11}$ & & & & $\alpha_{5,15}$ & $\alpha_{5,16}$ & \\
\hline 6 & Aerobic & & & & & & & & & & & & & & & & & \\
\hline & $\begin{array}{l}\text { growth on } \\
\mathrm{NO}_{3}^{-}\end{array}$ & & & & 1 & & & $\alpha_{6,7}$ & & $\alpha_{6,9}$ & & & & $\alpha_{6,13}$ & & $\alpha_{6,15}$ & $\alpha_{6,16}$ & \\
\hline 7 & $\begin{array}{l}\text { Aerobic } \\
\text { respiration }\end{array}$ & & & & -1 & & & & & $\alpha_{7,9}$ & & $\alpha_{7,11}$ & & & & $\alpha_{7,15}$ & -1 & \\
\hline 8 & $\begin{array}{l}\text { Anoxic growth } \\
\text { on } \mathrm{NO}_{3}{ }^{-}\end{array}$ & & & & 1 & & & $\alpha_{8,7}$ & & $\alpha_{8,9}$ & & $\alpha_{8,11}$ & & $\alpha_{8,13}$ & $\alpha_{8,14}$ & $\alpha_{8,15}$ & & \\
\hline 9 & $\begin{array}{l}\text { Anoxic growth } \\
\text { on } \mathrm{NO}_{2}^{-}\end{array}$ & & & & 1 & & & $\alpha_{9,7}$ & & $\alpha_{9,9}$ & & $\alpha_{9,11}$ & $\alpha_{9,12}$ & & $\alpha_{9,14}$ & $\alpha_{9,15}$ & & \\
\hline 10 & Anoxic & & & & & & & & & & & & & & & & & \\
\hline & $\begin{array}{l}\text { respiration } \\
\mathrm{NO}_{2}^{-} \text {and } \mathrm{NO}_{3}^{-}\end{array}$ & & & & -1 & & & & & $\alpha_{10,9}$ & & $\alpha_{10,11}$ & $\alpha_{10,12}$ & $\alpha_{10,13}$ & $\alpha_{10,14}$ & $\alpha_{10,15}$ & & \\
\hline 11 & $\begin{array}{l}\text { Hydrolysis of } \\
\text { slowly } \\
\text { biodegradable } \\
\text { COD }\end{array}$ & & & & & -1 & & $\alpha_{11,7}$ & $\alpha_{11,8}$ & $\alpha_{11,9}$ & & $\alpha_{11,11}$ & & & & $\alpha_{11,15}$ & & \\
\hline 12 & $\begin{array}{l}\text { Hydrolysis of } \\
\text { urea }\end{array}$ & & & & & & & & & $\alpha_{12,9}$ & -1 & 1 & & & & & & $\alpha_{12,17}$ \\
\hline 13 & Decay & & & & -1 & $\alpha_{13,5}$ & $\alpha_{13,6}$ & & & $\alpha_{13,9}$ & & $\alpha_{13,11}$ & & & & $\alpha_{13,15}$ & & \\
\hline \multicolumn{19}{|c|}{$\begin{array}{l}\text { Ammonium Oxydising Bacteria } \\
14 \quad \text { Aerobic }\end{array}$} \\
\hline 14 & $\begin{array}{l}\text { Aerobic } \\
\text { growth on } \\
\mathrm{NH}_{4}^{+}\end{array}$ & & 1 & & & & & & & $\alpha_{14,9}$ & & $\alpha_{14,11}$ & $\alpha_{14,12}$ & & & $\alpha_{14,15}$ & $\alpha_{14,16}$ & \\
\hline
\end{tabular}




\begin{tabular}{|c|c|c|c|c|c|c|c|c|c|c|c|c|c|c|c|c|c|c|}
\hline 15 & $\begin{array}{l}\text { Aerobic } \\
\text { respiration }\end{array}$ & & -1 & & & & & & & $\alpha_{15,9}$ & & $\alpha_{15,11}$ & & & & $\alpha_{15,15}$ & $\alpha_{15,16}$ & \\
\hline 16 & Decay & & -1 & & & $\alpha_{16,5}$ & $\alpha_{16,6}$ & & & $\alpha_{16,9}$ & & $\alpha_{16,11}$ & & & & $\alpha_{16,15}$ & & \\
\hline \multicolumn{19}{|c|}{ Nitrite Oxydising Bacteria } \\
\hline 17 & $\begin{array}{l}\text { Aerobic } \\
\text { growth on } \\
\mathrm{NO}_{2}^{-}\end{array}$ & & & 1 & & & & & & $a_{17,9}$ & & $\alpha_{17,11}$ & $\alpha_{17,12}$ & $\alpha_{17,13}$ & & $\alpha_{17,15}$ & $\alpha_{17,16}$ & \\
\hline 18 & $\begin{array}{l}\text { Aerobic } \\
\text { respiration }\end{array}$ & & & -1 & & & & & & $\alpha_{18,9}$ & & $\alpha_{18,11}$ & & & & $\alpha_{18,15}$ & $\alpha_{18,16}$ & \\
\hline 19 & Decay & & & -1 & & $\alpha_{19,5}$ & $\alpha_{19,6}$ & & & $\alpha_{19,9}$ & & $\alpha_{19,11}$ & & & & $\alpha_{19,15}$ & & \\
\hline \multicolumn{19}{|c|}{ Equilibrium phase } \\
\hline 20 & $\begin{array}{l}\text { Dissolution } \\
\text { of } \mathrm{O}_{2}\end{array}$ & & & & & & & & & & & & & & & & 1 & \\
\hline 21 & $\begin{array}{l}\text { Dissolution } \\
\text { of } \mathrm{CO}_{2}\end{array}$ & & & & & & & & & 1 & & & & & & & & \\
\hline 22 & $\begin{array}{l}\text { Dissolution } \\
\text { of } \mathrm{NH}_{3}\end{array}$ & & & & & & & & & & & 1 & & & & & & \\
\hline $\mathrm{k} \downarrow$ & $j \rightarrow$ & & & & & & & Cons & ative $r$ & ss bala & & & & & & & & \\
\hline 1 & $\begin{array}{l}\text { COD } \quad(4 \rightarrow \\
19)\end{array}$ & 1 & 1 & 1 & 1 & 1 & 1 & 1 & 1 & 0 & 0 & 0 & -3.43 & -4.57 & -1.71 & 0 & -1 & 0 \\
\hline 2 & $O(1 \rightarrow 3)$ & $-\mathrm{iO}_{\mathrm{BM}, \mathrm{ALG}}$ & $-\mathrm{iO}_{\mathrm{BM}}$ & $-\mathrm{iO}_{\mathrm{BM}}$ & $-\mathrm{iO}_{\mathrm{BM}}$ & $-\mathrm{iO}_{\mathrm{xS}}$ & $-i O_{x \mid}$ & $-\mathrm{iO}_{s s}$ & $-\mathrm{iO}_{S I}$ & -2.67 & 0 & 1.71 & -1.71 & -2.86 & 0 & -1.29 & 1 & -8 \\
\hline 3 & C & $\mathrm{iC}_{\mathrm{BM}, \mathrm{ALG}}$ & $\mathrm{iC}_{\mathrm{BM}}$ & $\mathrm{iC}_{\mathrm{BM}}$ & $\mathrm{iC}_{\mathrm{BM}}$ & $1 C_{x s}$ & $i \mathrm{C}_{\mathrm{xi}}$ & $\mathrm{iC}_{\mathrm{ss}}$ & $\mathrm{iC}_{\mathrm{si}}$ & 1 & 0 & 0 & 0 & 0 & 0 & 0 & 0 & 0 \\
\hline 4 & $\mathrm{~N}$ & iN & $\mathrm{i} \mathrm{N}_{\text {BM }}$ & $i \mathrm{~N}_{\mathrm{BM}}$ & $\mathrm{i} \mathrm{N}_{\mathrm{BM}}$ & $\mathbb{I N}_{\mathrm{Xs}_{\mathrm{s}}}$ & $\mathrm{iN}_{\mathrm{xi}}$ & $\mathrm{iN}_{\mathrm{ss}}$ & $\mathrm{iN}_{\mathrm{si}}$ & 0 & 1 & 1 & 1 & 1 & 1 & 0 & 0 & 0 \\
\hline 5 & $\mathrm{P}$ & iP $P_{\text {BM,ALG }}$ & $\mathrm{iP}_{\mathrm{BM}}$ & $\mathrm{iP}_{\mathrm{BM}}$ & $\mathrm{iP}_{\mathrm{BM}}$ & $\operatorname{IP}_{x_{s}}$ & $i P_{x i}$ & $\mathrm{iP}_{\mathrm{ss}}$ & $\mathrm{iP}_{\mathrm{si}}$ & 0 & 0 & 0 & 0 & 0 & 0 & 1 & 0 & 0 \\
\hline 6 & $\mathrm{H}(1 \rightarrow 3)$ & $\mathrm{iH}_{\mathrm{BM}, \mathrm{ALG}}$ & 0 & 0 & 0 & 0 & 0 & 0 & 0 & 0 & 0 & 0 & 0 & 0 & 0 & 0 & 0 & 1 \\
\hline
\end{tabular}


Table SI.3.2. Stoichiometric coefficient values implemented in the ALBA bioprocesses.

\begin{tabular}{|c|c|c|c|c|}
\hline Symbol & Definition & Value & Unit & Source \\
\hline \multicolumn{5}{|c|}{ ALGAE - BACTERIA } \\
\hline $\mathrm{fXI}_{\mathrm{X}, \mathrm{ALG}}$ & Inert organic fraction produced from microalgae decay & 0.062 & $\mathrm{gCOD}_{\mathrm{XI}} \mathrm{gCOD}-1$ & $\begin{array}{l}\text { This } \\
\text { study }\end{array}$ \\
\hline İ,$B M^{A L G}$ & Fraction of carbon in algae biomass & 0.327 & $\mathrm{gC} \mathrm{gCOD}_{\mathrm{BM}}^{-1}$ & $\begin{array}{l}\text { This } \\
\text { study }\end{array}$ \\
\hline $\mathrm{I}_{\mathrm{N}, \mathrm{BM}}^{\mathrm{ALG}}$ & Fraction of nitrogen in algae biomass & 0.042 & $\mathrm{gN} g \mathrm{gOD}_{\mathrm{BM}}^{-1}$ & $\begin{array}{l}\text { This } \\
\text { study }\end{array}$ \\
\hline $\mathrm{I}_{\mathrm{P}, \mathrm{BM}}^{\mathrm{ALG}}$ & Fraction of phosphorus in algae biomass & 0.008 & $\mathrm{gP} \mathrm{gCOD}_{\mathrm{BM}}^{-1}$ & $\begin{array}{l}\text { This } \\
\text { study }\end{array}$ \\
\hline Io,BM ${ }^{A L G}$ & Fraction of oxygen in algae biomass & 0.209 & $\mathrm{gO} \mathrm{gCOD}_{\mathrm{BM}}^{-1}$ & $\begin{array}{l}\text { This } \\
\text { study }\end{array}$ \\
\hline $\mathrm{I}_{\mathrm{H}, \mathrm{BM}} \mathrm{ALG}^{\mathrm{ALG}}$ & Fraction of hydrogen in algae biomass & 0.050 & $\mathrm{gH} \mathrm{gCOD}_{\mathrm{BM}}^{-1}$ & $\begin{array}{l}\text { This } \\
\text { study }\end{array}$ \\
\hline$f_{S I}$ & $\begin{array}{l}\text { Inert soluble organic fraction produced from } \\
\text { hydrolysis }\end{array}$ & 0.1 & $\mathrm{gCOD}_{\mathrm{SI}} \mathrm{gCOD}-1$ & $\begin{array}{l}\text { Henze, } \\
2000\end{array}$ \\
\hline$f_{X I}$ & Inert organic fraction produced from bacteria decay & 0.1 & $\mathrm{gCOD}_{\mathrm{XI}} \mathrm{gCOD}-1$ & $\begin{array}{l}\text { Henze, } \\
2000\end{array}$ \\
\hline íc,BM & $\begin{array}{l}\text { Fraction of carbon in bacterial biomass (nitrifiers, } \\
\text { heterotrophs) }\end{array}$ & 0.36 & $\mathrm{gC} \mathrm{gCOD}-1$ & $\begin{array}{l}\text { This } \\
\text { study }\end{array}$ \\
\hline ín,BM & $\begin{array}{l}\text { Fraction of nitrogen in bacterial biomass (nitrifiers, } \\
\text { heterotrophs) }\end{array}$ & 0.084 & $\mathrm{gN} g C O D_{\mathrm{BM}}^{-1}$ & $\begin{array}{l}\text { This } \\
\text { study }\end{array}$ \\
\hline İ,BM & $\begin{array}{l}\text { Fraction of phosphorus in bacterial biomass (nitrifiers, } \\
\text { heterotrophs) }\end{array}$ & 0.016 & $\mathrm{gP} g C O D_{\mathrm{BM}}^{-1}$ & $\begin{array}{l}\text { This } \\
\text { study }\end{array}$ \\
\hline İo,BM & $\begin{array}{l}\text { Fraction of oxygen in bacterial biomass (nitrifiers, } \\
\text { heterotrophs) }\end{array}$ & 0.184 & $\mathrm{gO} \mathrm{gCOD}_{\mathrm{BM}}^{-1}$ & $\begin{array}{l}\text { This } \\
\text { study }\end{array}$ \\
\hline $\mathrm{I}_{\mathrm{H}, \mathrm{BM}}$ & $\begin{array}{l}\text { Fraction of hydrogen in bacterial biomass (nitrifiers, } \\
\text { heterotrophs) }\end{array}$ & 0.043 & $\mathrm{gH} \mathrm{gCOD}_{\mathrm{BM}}^{-1}$ & $\begin{array}{l}\text { This } \\
\text { study }\end{array}$ \\
\hline ic,ss & Fraction of carbon in soluble organic matter $\left(\mathrm{S}_{\mathrm{s}}\right)$ & 0.318 & $\mathrm{gC} g \mathrm{gOD}_{\mathrm{SS}}^{-1}$ & $\begin{array}{l}\text { Reichert, } \\
2001\end{array}$ \\
\hline in,ss & Fraction of nitrogen in soluble organic matter (SS) & 0.015 & $\mathrm{gN} g \mathrm{gCOD}_{\mathrm{SS}}^{-1}$ & $\begin{array}{l}\text { This } \\
\text { study }\end{array}$ \\
\hline ip,ss & Fraction of phosphorus in soluble organic matter (SS) & 0.005 & $\mathrm{gP}_{\mathrm{gCOD}}^{-1}$ & $\begin{array}{l}\text { Reichert, } \\
2001\end{array}$ \\
\hline İo,ss & Fraction of oxygen in soluble organic matter (SS) & 0.156 & $\mathrm{gO} \mathrm{gCOD}_{\mathrm{SS}}^{-1}$ & $\begin{array}{l}\text { Reichert, } \\
2001\end{array}$ \\
\hline íc,SI & $\begin{array}{l}\text { Fraction of carbon in soluble recalcitrant organic } \\
\text { matter (SI) }\end{array}$ & 0.36 & $\mathrm{gC} \mathrm{gCOD} \mathrm{SI}^{-1}$ & $\begin{array}{l}\text { Batstone, } \\
2002\end{array}$ \\
\hline $\mathrm{i}_{\mathrm{N}, \mathrm{SI}}$ & $\begin{array}{l}\text { Fraction of nitrogen in soluble recalcitrant organic } \\
\text { matter }(\mathrm{SI})\end{array}$ & 0.06 & $\mathrm{gN} g \mathrm{COD}_{\mathrm{SI}}^{-1}$ & $\begin{array}{l}\text { Batstone, } \\
2002\end{array}$ \\
\hline IP,SI & $\begin{array}{l}\text { Fraction of phosphorus in soluble recalcitrant organic } \\
\text { matter (SI) }\end{array}$ & 0.005 & $\mathrm{gP}_{\mathrm{gCOD}}^{-1}$ & $\begin{array}{l}\text { Reichert, } \\
2001\end{array}$ \\
\hline ío,sı & $\begin{array}{l}\text { Fraction of oxygen in soluble recalcitrant organic } \\
\text { matter (SI) }\end{array}$ & 0.15 & $\mathrm{gO} \mathrm{gCOD}_{\mathrm{SI}}^{-1}$ & $\begin{array}{l}\text { Reichert, } \\
2001\end{array}$ \\
\hline $\mathrm{YH}_{\mathrm{H}}$ & Growth yield for heterotrophic bacteria & 0.63 & $\mathrm{gCOD}_{\mathrm{BM}} \mathrm{gCOD}_{\mathrm{SS}}^{-1}$ & $\begin{array}{l}\text { Henze, } \\
2000\end{array}$ \\
\hline $\mathrm{YH}_{\mathrm{H}, \mathrm{NO} 2}$ & $\begin{array}{l}\text { Growth yield for heterotrophic bacteria, denitrification } \\
\text { on } \mathrm{NO}_{2}^{-}\end{array}$ & 0.3 & $\mathrm{gCOD}_{\mathrm{BM}} \mathrm{gCOD}_{\mathrm{SS}}^{-1}$ & $\begin{array}{l}\text { Reichert, } \\
2001\end{array}$ \\
\hline $\mathrm{YH}_{\mathrm{H}, \mathrm{NO} 3}$ & $\begin{array}{l}\text { Growth yield for heterotrophic bacteria, denitrification } \\
\text { on } \mathrm{NO}_{3}^{-}\end{array}$ & 0.5 & $\mathrm{gCOD}_{\mathrm{BM}} \mathrm{gCOD}_{\mathrm{SS}}^{-1}$ & $\begin{array}{l}\text { Reichert, } \\
2001\end{array}$ \\
\hline $\mathrm{Y}_{\mathrm{AOB}}$ & Growth yield factor for $A O B$ & 0.2 & $\mathrm{gCOD}_{\mathrm{BM}} \mathrm{gN}^{-1}$ & $\begin{array}{l}\text { Arashiro, } \\
2016\end{array}$ \\
\hline $\mathrm{Y}_{\mathrm{NOB}}$ & Growth yield for NOB & 0.05 & $\mathrm{gCOD}_{\mathrm{BM}} \mathrm{gN}^{-1}$ & $\begin{array}{l}\text { Arashiro, } \\
2016\end{array}$ \\
\hline İC,ND & $\begin{array}{l}\text { Fraction of inorganic carbon from urea hydrolysis } \\
\left(\mathrm{S}_{\mathrm{ND}}\right)\end{array}$ & 0.429 & $g C \mathrm{gN}_{\text {urea }}^{-1}$ & $\begin{array}{l}\text { This } \\
\text { study }\end{array}$ \\
\hline $\mathrm{I}_{\mathrm{H}, \mathrm{ND}}$ & Fraction of hydrogen from urea hydrolysis $\left(\mathrm{S}_{\mathrm{ND}}\right)$ & 0.071 & $\mathrm{gH} \mathrm{gN}_{\text {urea }}^{-1}$ & $\begin{array}{l}\text { This } \\
\text { study }\end{array}$ \\
\hline ic, $x s$ & Fraction of carbon in particulate biodegradable & 0.318 & $g C g C O D_{X S}^{-1}$ & Reichert, \\
\hline
\end{tabular}


organic matter

ic,Xl Fraction of carbon in particulate inert organic matter

$\mathrm{in}_{\mathrm{N}, \mathrm{XS}}$

$\mathrm{i}_{\mathrm{N}, \mathrm{XI}}$

$\mathrm{iP}_{\mathrm{P}, \mathrm{XS}}$

IP,XI

i̇o,xs

İo,XI

Fraction nitrogen in particulate biodegradable organic matter

Fraction of nitrogen in particulate inert organic matter

Fraction of phosphorus in particulate biodegradable organic matter

Fraction of phosphorus in particulate inert organic matter

Fraction of oxygen in particulate biodegradable

organic matter

Fraction of oxygen in particulate inert organic matter 
Table SI.3.3: Stoichiometric coefficient expressions

Stoichiometric coefficients

\begin{tabular}{|c|c|c|c|}
\hline Symbol & Affected variable & Expression & Unit \\
\hline \multicolumn{4}{|c|}{$\rho_{1}$ - Growth of $\mathrm{X}_{\mathrm{ALG}}$ on $\mathrm{NH}_{4}^{+}$} \\
\hline$\alpha_{1,1}$ & $\mathrm{X}_{\mathrm{ALG}}$ & 1 & \multirow{5}{*}{$\begin{array}{c}\mathrm{gCOD}_{\mathrm{BM}} / \mathrm{gCOD}_{\mathrm{BM}} \\
\mathrm{gC} / \mathrm{gCOD} \mathrm{D}_{\mathrm{BM}} \\
\mathrm{gN} / \mathrm{gCOD} \\
\mathrm{gP} / \mathrm{gCOD} \\
\mathrm{gO}_{2} / \mathrm{gCOD} \\
\mathrm{BM}\end{array}$} \\
\hline $\mathbf{a}_{1,9}$ & $S_{I C}$ & $-i C_{B M}{ }^{A L G}$ & \\
\hline$\alpha_{1,11}$ & $\mathrm{~S}_{\mathrm{NH}}$ & $-i N_{B M}{ }^{A L G}$ & \\
\hline$\alpha_{1,15}$ & $\mathrm{~S}_{\mathrm{PO} 4}$ & \multirow{3}{*}{ 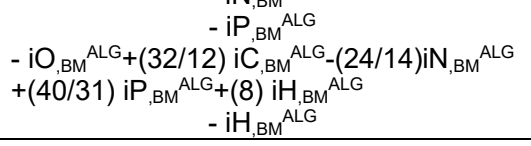 } & \\
\hline$\alpha_{1,16}$ & $\mathrm{~S}_{\mathrm{O} 2}$ & & \\
\hline$\alpha_{1,17}$ & $\mathrm{~S}_{\mathrm{H} 2 \mathrm{O}}$ & & $\mathrm{gH} / \mathrm{gCOD}_{\mathrm{BM}}$ \\
\hline \multicolumn{4}{|c|}{$\rho_{2}-$ Growth of $\mathrm{X}_{\mathrm{ALG}}$ on $\mathrm{NO}_{3}^{-}$} \\
\hline$\alpha_{21}$ & $X_{A L G}$ & 1 & \multirow{5}{*}{$\begin{array}{c}\mathrm{gCOD}_{\mathrm{BM}} / \mathrm{gCOD}_{\mathrm{BM}} \\
\mathrm{gC} / \mathrm{gCOD} \mathrm{D}_{\mathrm{BM}} \\
\mathrm{gN} / \mathrm{gCOD} \mathrm{D}_{\mathrm{BM}} \\
\mathrm{gP} / \mathrm{gCOD} \\
\mathrm{gO} / \mathrm{gCOD} \\
\mathrm{BM}\end{array}$} \\
\hline$\alpha_{2,9}$ & $S_{I C}$ & \multirow{5}{*}{ 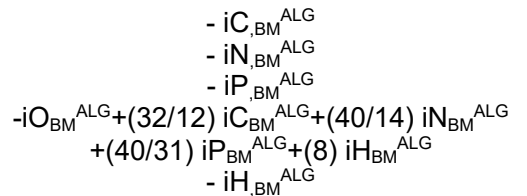 } & \\
\hline$a_{2,13}$ & $\mathrm{~S}_{\mathrm{NO} 3}$ & & \\
\hline$a_{2,15}$ & $\mathrm{SPO}_{\mathrm{PO}}$ & & \\
\hline$\alpha_{2,16}$ & $\mathrm{~S}_{\mathrm{O} 2}$ & & \\
\hline$\alpha_{2,17}$ & $\mathrm{~S}_{\mathrm{H} 2 \mathrm{O}}$ & & $\mathrm{gH} / \mathrm{gCOD}{ }_{\mathrm{BM}}$ \\
\hline \multicolumn{4}{|c|}{$\rho_{3}-$ Aerobic respiration of $X_{A L G}$} \\
\hline$\alpha_{3,1}$ & $\mathrm{X}_{\mathrm{ALG}}$ & \multirow{6}{*}{ 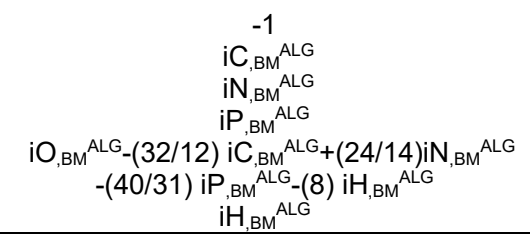 } & \multirow{6}{*}{$\begin{array}{c}\mathrm{gCOD}_{\mathrm{BM}} / \mathrm{gCOD}_{\mathrm{BM}} \\
\mathrm{gC} / \mathrm{g} \mathrm{COD}_{\mathrm{BM}} \\
\mathrm{gN} / \mathrm{gCOD} \\
\mathrm{gP}_{\mathrm{BM}} / \mathrm{gCOD} \\
\mathrm{gO}_{2} / \mathrm{gCOD} \\
\\
\mathrm{gH} / \mathrm{gCOD} \\
\end{array}$} \\
\hline$\alpha_{3,9}$ & $\mathrm{~S}_{\mathrm{IC}}$ & & \\
\hline$a_{3,11}$ & $\mathrm{~S}_{\mathrm{NH}}$ & & \\
\hline$a_{3,15}$ & $\mathrm{~S}_{\mathrm{PO} 4}$ & & \\
\hline$\alpha_{3,16}$ & $\mathrm{~S}_{\mathrm{O} 2}$ & & \\
\hline$\alpha_{3,17}$ & $\mathrm{~S}_{\mathrm{H} 2 \mathrm{O}}$ & & \\
\hline \multicolumn{3}{|c|}{$\rho_{4}-$ Decay of $X_{A L G}$} & \multirow{7}{*}{$\begin{array}{c}\mathrm{gCOD}_{\mathrm{BM}} / \mathrm{gCOD}_{\mathrm{BM}} \\
\mathrm{gCOD} \mathrm{DS}_{\mathrm{XS}} / \mathrm{gCOD}_{\mathrm{BM}} \\
\mathrm{gC} / \mathrm{gCOD} \mathrm{B}_{\mathrm{BM}} \\
\mathrm{gN} / \mathrm{gCOD} \mathrm{BM}_{\mathrm{BM}} \\
\mathrm{gP} / \mathrm{g} C O D_{\mathrm{BM}}\end{array}$} \\
\hline$\alpha_{4,1}$ & $\mathrm{X}_{\mathrm{ALG}}$ & -1 & \\
\hline$\alpha_{4,5}$ & $X_{S}$ & $\left(1-f_{X I, A L G}\right)$ & \\
\hline$\alpha_{4,6}$ & $x_{1}$ & $\mathrm{f}_{\mathrm{XI}, A L \mathrm{G}}$ & \\
\hline$\alpha_{4,9}$ & $S_{I C}$ & $i C_{B M}{ }^{A L G}-\left(1-f_{X I, A L G}\right)^{*} i C_{X S}-f_{X I, A L G} * i C_{X I}$ & \\
\hline$\alpha_{4,11}$ & $\mathrm{~S}_{\mathrm{NH}}$ & $\mathrm{iN}_{\mathrm{BM}}{ }^{A L G}-\left(1-f_{X I, A L G}\right)^{* i} N_{X S^{-}}-f_{X I, A L G}{ }^{*} i N_{X I}$ & \\
\hline$a_{415}$ & $\mathrm{~S}_{\mathrm{PO4}}$ & ${ } P_{B M}{ }^{A L G}-\left(1-f_{X I A L G}\right)^{*} i P_{X S^{-}} f_{X \mid A L G}{ }^{*} P_{X \mid}$ & \\
\hline \multicolumn{4}{|c|}{$\rho_{5}-$ Aerobic growth of $\mathrm{X}_{\mathrm{H}}$ on $\mathrm{NH}_{4}^{+}$} \\
\hline$\alpha_{5,3}$ & $X_{H}$ & 1 & \multirow{6}{*}{$\begin{array}{c}\mathrm{gCOD}_{\mathrm{BM}} / \mathrm{gCOD}_{\mathrm{BM}} \\
\mathrm{gCOD} / \mathrm{gs} / \mathrm{gCOD}_{\mathrm{BM}} \\
\mathrm{gC} / \mathrm{gCOD} \mathrm{BM}_{\mathrm{BM}} \\
\mathrm{gN} / \mathrm{gCOD} \mathrm{BM}_{\mathrm{BM}} \\
\mathrm{gP} / \mathrm{gCOD}_{\mathrm{BM}} \\
\mathrm{gO}_{2} / \mathrm{gCOD}_{\mathrm{BM}}\end{array}$} \\
\hline$a_{5,7}$ & $\mathrm{~S}_{\mathrm{s}}$ & $-1 / Y_{H}$ & \\
\hline$\alpha_{5,9}$ & $S_{I C}$ & $i C_{S S} / Y_{H}-i C_{B M}$ & \\
\hline$\alpha_{5,11}$ & $\mathrm{~S}_{\mathrm{NH}}$ & $\mathrm{i} \mathrm{N}_{\mathrm{SS}} / \mathrm{Y}_{\mathrm{H}}-\mathrm{i} \mathrm{N}_{\mathrm{BM}}$ & \\
\hline$\alpha_{5,15}$ & $\mathrm{~S}_{\mathrm{PO} 4}$ & $\mathrm{i} \mathrm{PSS}_{\mathrm{SS}} / \mathrm{Y}_{\mathrm{H}}-\mathrm{i} \mathrm{P}_{\mathrm{BM}}$ & \\
\hline$a_{5,16}$ & $\mathrm{~S}_{\mathrm{O} 2}$ & $-\left(1 / Y_{H^{-1}}\right)$ & \\
\hline$\rho_{6}-$ Aero & jic growth of $\mathrm{X}_{\mathrm{H}}$ on $\mathrm{N}$ & & \\
\hline$\alpha_{6,4}$ & $X_{H}$ & 1 & $\mathrm{gCOD}_{\mathrm{BM}} / \mathrm{gCOD}_{\mathrm{BM}}$ \\
\hline$a_{6,7}$ & $S_{s}$ & $-1 / Y_{H}$ & $\mathrm{gCOD}_{\mathrm{SS}} / \mathrm{gCOD}_{\mathrm{BM}}$ \\
\hline $\mathbf{a}_{6,9}$ & $S_{I C}$ & $\mathrm{iC} \mathrm{CSS}_{\mathrm{SS}} / \mathrm{Y}_{\mathrm{H}^{-}} \mathrm{i} \mathrm{C}_{\mathrm{BM}}$ & $\mathrm{gC} / \mathrm{gCOD} D_{\mathrm{BM}}$ \\
\hline$\alpha_{6,13}$ & $\mathrm{~S}_{\mathrm{NO} 3}$ & $i N_{S S} / Y_{H^{-}}-\mathrm{i} N_{B M}$ & $\mathrm{gN} / \mathrm{gCOD}{ }_{\mathrm{BM}}$ \\
\hline$\alpha_{6,15}$ & $\mathrm{~S}_{\mathrm{PO} 4}$ & $\mathrm{iP} \mathrm{PSS}_{\mathrm{S}} / \mathrm{Y}_{\mathrm{H}^{-}} \mathrm{iP} \mathrm{P}_{\mathrm{BM}}$ & $\mathrm{gP} / \mathrm{gCOD}_{\mathrm{BM}}$ \\
\hline$\alpha_{6,16}$ & $\mathrm{~S}_{\mathrm{O} 2}$ & $-\left(1 / Y_{H}-1\right)-64 / 14^{*}\left(i N_{S S} / Y_{H^{-}}-i N_{B M}\right)$ & $\mathrm{gO}_{2} / \mathrm{gCOD}_{\mathrm{BM}}$ \\
\hline$\rho_{7}-$ Aero & jic respiration of $X_{H}$ & & \\
\hline$\alpha_{7,4}$ & $X_{H}$ & -1 & $\mathrm{gCOD}_{\mathrm{BM}} / \mathrm{gCOD}_{\mathrm{BM}}$ \\
\hline$\alpha_{7,9}$ & $S_{I C}$ & $\mathrm{iC}_{\mathrm{BM}}$ & $\mathrm{gC} / \mathrm{gCOD}_{\mathrm{BM}}$ \\
\hline$\alpha_{7,11}$ & $\mathrm{~S}_{\mathrm{NH}}$ & $i N_{B M}$ & $\mathrm{gN} / \mathrm{gCOD} \mathrm{BM}_{\mathrm{B}}$ \\
\hline$\alpha_{7,15}$ & $\mathrm{~S}_{\mathrm{PO} 4}$ & $\mathrm{iP}_{\mathrm{BM}}$ & $\mathrm{gP} / \mathrm{gCOD}_{\mathrm{BM}}$ \\
\hline$\alpha_{7,16}$ & $\mathrm{~S}_{\mathrm{O} 2}$ & -1 & $\mathrm{gO}_{2} / \mathrm{gCOD}_{\mathrm{BM}}$ \\
\hline$\rho_{8}-$ Anox & ic growth of $X_{H}$ on $N C$ & & \\
\hline$\alpha_{8,4}$ & $X_{H}$ & 1 & $\mathrm{gCOD}_{\mathrm{BM}} / \mathrm{gCOD}_{\mathrm{BM}}$ \\
\hline$\alpha_{8,7}$ & $\hat{S}_{S}^{H}$ & $-1 / Y_{\mathrm{HNO}}$ & $\mathrm{gCOD}_{\mathrm{SS}} / \mathrm{gCOD} \mathrm{B}_{\mathrm{BM}}$ \\
\hline$\alpha_{8,9}$ & $\mathrm{~S}_{\mathrm{IC}}$ & $\mathrm{iC}_{\mathrm{SS}} / \mathrm{Y}_{\mathrm{HNO} 3}-\mathrm{i} \mathrm{C}_{\mathrm{BM}}$ & $\mathrm{gC} / \mathrm{gCOD} \mathrm{BM}_{\mathrm{BM}}$ \\
\hline$\alpha_{8,11}$ & $\mathrm{~S}_{\mathrm{NH}}$ & $\mathrm{iN} \mathrm{SS}_{\mathrm{S}} / \mathrm{Y}_{\mathrm{HNO} 3}-\mathrm{i} \mathrm{N}_{\mathrm{BM}}$ & $\mathrm{gN} / \mathrm{g} C O D_{\mathrm{BM}}$ \\
\hline$\alpha_{8,13}$ & $\mathrm{~S}_{\mathrm{NO} 3}$ & $-28 / 80 *\left(1 / \mathrm{Y}_{\mathrm{HNO}^{3}}-1\right)$ & $\mathrm{gN} / \mathrm{gCOD}$ ВM \\
\hline$\alpha_{8,14}$ & $\mathrm{~S}_{\mathrm{N} 2}$ & $28 / 80^{\star}\left(1 / \mathrm{Y}_{\mathrm{HNO}^{3}}-1\right)$ & $\mathrm{gN} / \mathrm{gCOD}$ BM \\
\hline$\alpha_{8,15}$ & $\mathrm{~S}_{\mathrm{PO} 4}$ & $\mathrm{i} \mathrm{P}_{\mathrm{SS}} / \mathrm{Y}_{\mathrm{HNO} 3}-\mathrm{iP}_{\mathrm{BM}}$ & $\mathrm{gP} / \mathrm{gCOD} \mathrm{D}_{\mathrm{BM}}$ \\
\hline$\rho_{9}-$ Anox & ic growth of $\mathrm{X}_{\mathrm{H}}$ on $\mathrm{NC}$ & & \\
\hline$\alpha_{9,4}$ & $X_{H}$ & 1 & $\mathrm{gCOD}_{\mathrm{BM}} / \mathrm{gCOD}_{\mathrm{BM}}$ \\
\hline$\alpha_{9,7}$ & $\mathrm{~S}_{\mathrm{S}}$ & $-1 / Y_{\mathrm{HNO} 2}$ & $\mathrm{gCOD}_{\mathrm{SS}} / \mathrm{gCOD}_{\mathrm{BM}}$ \\
\hline$\alpha_{9,9}$ & $\mathrm{~S}_{\mathrm{IC}}$ & $\mathrm{iC}_{\mathrm{SS}} / \mathrm{Y}_{\mathrm{HNO} 2}-\mathrm{i} \mathrm{C}_{\mathrm{BM}}$ & $\mathrm{gC} / \mathrm{gCOD} \mathrm{B}_{\mathrm{BM}}$ \\
\hline$\alpha_{9,11}$ & $\mathrm{~S}_{\mathrm{NH}}$ & $\mathrm{i} \mathrm{N}_{\mathrm{SS}} / Y_{\mathrm{HNO} 2}-\mathrm{iN}_{\mathrm{BM}}$ & $\mathrm{gN} / \mathrm{g} C O D_{\mathrm{BM}}$ \\
\hline$\alpha_{9,12}$ & $\mathrm{~S}_{\mathrm{NO} 2}$ & $-28 / 48^{*}\left(1 / Y_{\mathrm{HNO} 2}-1\right)$ & $\mathrm{gN} / \mathrm{gCOD}$ BM \\
\hline$\alpha_{9,14}$ & $\mathrm{~S}_{\mathrm{N} 2}$ & $28 / 48^{*}\left(1 / \mathrm{Y}_{\mathrm{HNO}}-1\right)$ & $\mathrm{gN} / \mathrm{gCOD} \mathrm{D}_{\mathrm{BM}}$ \\
\hline$\alpha_{9,15}$ & $\mathrm{~S}_{\mathrm{PO} 4}$ & $\mathrm{iP}_{\mathrm{SS}} / \mathrm{Y}_{\mathrm{HNO} 2}-\mathrm{iP}_{\mathrm{BM}}$ & $\mathrm{gP} / \mathrm{gCOD}$ BM \\
\hline$\rho_{10}-$ Anox & respiration of $X_{H}$ & $\mathrm{NO}_{2}^{-}$and $\mathrm{NO}_{3}^{-}$ & \\
\hline$\alpha_{10,4}$ & $X_{H}$ & -1 & $\mathrm{gCOD}_{\mathrm{BM}} / \mathrm{gCOD}_{\mathrm{BM}}$ \\
\hline$\alpha_{10,9}$ & $\mathrm{~S}_{\mathrm{IC}}$ & $i C_{B M}$ & $\mathrm{gC} / \mathrm{gCO} \mathrm{D}_{\mathrm{BM}}$ \\
\hline$a_{10,11}$ & $\mathrm{~S}_{\mathrm{NH}}$ & $\mathrm{iN}_{\mathrm{BM}}$ & $\mathrm{gN} / \mathrm{gCOD} \mathrm{BM}_{\mathrm{BM}}$ \\
\hline
\end{tabular}




\begin{tabular}{|c|c|c|c|}
\hline $\begin{array}{l}\alpha_{10,12} \\
\alpha_{10,13} \\
\alpha_{10,14} \\
\alpha_{10,15} \\
\end{array}$ & $\begin{array}{l}\mathrm{S}_{\mathrm{NO} 2} \\
\mathrm{~S}_{\mathrm{NO} 3} \\
\mathrm{~S}_{\mathrm{N} 2} \\
\mathrm{~S}_{\mathrm{PO} 4}\end{array}$ & $\begin{array}{c}-14 / 64 \\
-14 / 64 \\
28 / 64 \\
\mathrm{iP}_{\mathrm{BM}} \\
\end{array}$ & $\begin{array}{l}\mathrm{gN} / \mathrm{gCOD} D_{\mathrm{BM}} \\
\mathrm{gN} / \mathrm{gCOD}{ }_{\mathrm{BM}} \\
\mathrm{gN} / \mathrm{gCOD}{ }_{\mathrm{BM}} \\
\mathrm{gP} / \mathrm{gCOD}_{\mathrm{BM}}\end{array}$ \\
\hline \multicolumn{4}{|c|}{$\rho_{11}-$ Hydrolysis of slowly biodegradable COD } \\
\hline $\begin{array}{l}\alpha_{11,5} \\
\alpha_{11,7} \\
\alpha_{11,8} \\
\alpha_{11,9} \\
\alpha_{11,11} \\
\alpha_{11,15} \\
\end{array}$ & $\begin{array}{l}\mathrm{X}_{\mathrm{S}} \\
\mathrm{S}_{\mathrm{S}} \\
\mathrm{S}_{\mathrm{I}} \\
\mathrm{S}_{\mathrm{IC}} \\
\mathrm{S}_{\mathrm{NH}} \\
\mathrm{S}_{\mathrm{PO} 4} \\
\end{array}$ & $\begin{array}{c}1 \\
1-f_{S I} \\
f_{S I} \\
i C_{X S}-\left(1-f_{S I}\right)^{* i} C_{S S}-f_{S I}{ }^{*} i C_{S I} \\
i N_{X S}-\left(1-f_{S I}\right)^{*} i_{S S}-f_{S I}{ }^{*} i N_{S I} \\
i P_{X S}-\left(1-f_{S I}\right)^{* i} P_{S S}-f_{S I}{ }^{*}{ }^{*} P_{S I}\end{array}$ & $\begin{array}{c}\mathrm{gCOD}_{x \mathrm{~s}} / \mathrm{gCOD}_{\mathrm{xs}} \\
\mathrm{gCOD}_{\mathrm{ss}} / \mathrm{gCOD}_{\mathrm{xs}} \\
\mathrm{gCOD}_{\mathrm{sl}} / \mathrm{gCOD}_{\mathrm{xs}} \\
\mathrm{gC} / \mathrm{g} C O D_{x s} \\
\mathrm{gN} / \mathrm{g} C O D_{x s} \\
\mathrm{gP} / \mathrm{gCOD} \\
\mathrm{xs}\end{array}$ \\
\hline \multicolumn{4}{|c|}{$\rho_{12}-$ Hydrolysis of urea } \\
\hline $\begin{array}{l}\alpha_{12,9} \\
\alpha_{12,10} \\
\alpha_{12,11} \\
\alpha_{12,17} \\
\end{array}$ & $\begin{array}{l}\mathrm{S}_{\mathrm{IC}} \\
\mathrm{S}_{\mathrm{ND}} \\
\mathrm{S}_{\mathrm{NH}} \\
\mathrm{S}_{\mathrm{H} 2 \mathrm{O}} \\
\end{array}$ & $\begin{array}{c}\mathrm{iC}_{\mathrm{ND}} \\
-1 \\
1 \\
\mathrm{i} \mathrm{H}_{\mathrm{ND}} \\
\end{array}$ & $\begin{array}{c}\mathrm{gC} / \mathrm{gN}_{\text {urea }} \\
\mathrm{gN}_{\text {urea }} / \mathrm{gN}_{\text {urea }} \\
\mathrm{gN}_{\text {ammonia }} / \mathrm{gN}_{\text {urea }} \\
\mathrm{gH} / \mathrm{gN}_{\text {urea }}\end{array}$ \\
\hline \multicolumn{4}{|c|}{$\rho_{13}-$ Decay of $X_{H}$} \\
\hline $\begin{array}{l}\alpha_{13,4} \\
\alpha_{13,5} \\
\alpha_{13,6} \\
\alpha_{13,9} \\
\alpha_{13,11} \\
\alpha_{13,15} \\
\end{array}$ & $\begin{array}{l}X_{H} \\
X_{S} \\
X_{1} \\
S_{I C} \\
S_{N H} \\
S_{P O 4} \\
\end{array}$ & $\begin{array}{c}-1 \\
1-f_{X I} \\
f_{X I} \\
i C_{B M}-\left(1-f_{X I}\right)^{* i} C_{X S}-f_{X X}{ }^{*} i C_{X I} \\
i N_{B M}-\left(1-f_{X I}\right)^{* i} N_{X S}-f_{X I}{ }^{* i} N_{X I} \\
i P_{B M}-\left(1-f_{X I}\right)^{*} i P_{X S}-f_{X I}{ }^{*} i P_{X I}\end{array}$ & 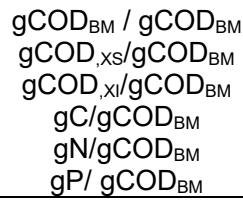 \\
\hline \multicolumn{4}{|c|}{$\rho_{14}-$ Aerobic growth of $\mathrm{X}_{\mathrm{AOB}}$ on $\mathrm{NH}_{4}^{+}$} \\
\hline $\begin{array}{l}\alpha_{14,2} \\
\alpha_{14,9} \\
\alpha_{14,11} \\
\alpha_{14,12} \\
\alpha_{14,15} \\
\alpha_{14,16} \\
\end{array}$ & $\begin{array}{l}\mathrm{X}_{\mathrm{AOB}} \\
\mathrm{S}_{\mathrm{IC}} \\
\mathrm{S}_{\mathrm{NH}} \\
\mathrm{S}_{\mathrm{NO} 2} \\
\mathrm{~S}_{\mathrm{PO4}} \\
\mathrm{S}_{\mathrm{O} 2} \\
\end{array}$ & $\begin{array}{c}1 \\
-\mathrm{i} \mathrm{C}_{\mathrm{BM}} \\
-\mathrm{i} \mathrm{N}_{\mathrm{BM}}-1 / \mathrm{Y}_{\mathrm{AOB}} \\
1 / \mathrm{Y}_{\mathrm{AOB}} \\
-\mathrm{iP}_{\mathrm{BM}} \\
1-48 / 14^{*} 1 / \mathrm{Y}_{\mathrm{AOB}} \\
\end{array}$ & $\begin{array}{c}\mathrm{gCOD}_{\mathrm{BM}} / \mathrm{gCOD}_{\mathrm{BM}} \\
\mathrm{gC} / \mathrm{gCOD} \mathrm{BM}_{\mathrm{BM}} \\
\mathrm{gN} / \mathrm{gCOD}_{\mathrm{BM}} \\
\mathrm{gN} / \mathrm{gCOD} \mathrm{BM}_{\mathrm{BM}} \\
\mathrm{gP} / \mathrm{gCOD}_{\mathrm{BM}} \\
\mathrm{gO}_{2} / \mathrm{gCOD}_{\mathrm{BM}} \\
\end{array}$ \\
\hline \multicolumn{4}{|c|}{$\rho_{15}-$ Aerobic respiration of $X_{A O B}$} \\
\hline $\begin{array}{l}\alpha_{15,2} \\
\alpha_{15,9} \\
\alpha_{15,11} \\
\alpha_{15,15} \\
\alpha_{15,16}\end{array}$ & $\begin{array}{l}\mathrm{X}_{\mathrm{AOB}} \\
\mathrm{S}_{\mathrm{IC}} \\
\mathrm{S}_{\mathrm{NH}} \\
\mathrm{S}_{\mathrm{PO} 4} \\
\mathrm{~S}_{\mathrm{O} 2}\end{array}$ & $\begin{array}{l}-1 \\
\mathrm{iC}_{\mathrm{BM}} \\
\mathrm{i} \mathrm{N}_{\mathrm{BM}} \\
\mathrm{iP}_{\mathrm{BM}} \\
-1\end{array}$ & $\begin{array}{c}\mathrm{gCOD}_{\mathrm{BM}} / \mathrm{gCOD}_{\mathrm{BM}} \\
\mathrm{gC} / \mathrm{g} \mathrm{COD}_{\mathrm{BM}} \\
\mathrm{gN} / \mathrm{gCOD} \mathrm{BM}_{\mathrm{BM}} \\
\mathrm{gP} / \mathrm{gCOD}_{\mathrm{BM}} \\
\mathrm{gO}_{2} / \mathrm{gCOD}_{\mathrm{BM}}\end{array}$ \\
\hline \multicolumn{4}{|c|}{$\rho_{16}-$ Decay of $X_{A O B}$} \\
\hline $\begin{array}{l}\alpha_{16,2} \\
\alpha_{16,5} \\
\alpha_{16,6} \\
\alpha_{16,9} \\
\alpha_{16,11} \\
\alpha_{16,15} \\
\end{array}$ & $\begin{array}{l}\mathrm{X}_{\mathrm{AOB}} \\
\mathrm{X}_{\mathrm{S}} \\
\mathrm{X}_{1} \\
\mathrm{~S}_{\mathrm{IC}} \\
\mathrm{S}_{\mathrm{NH}} \\
\mathrm{S}_{\mathrm{PO} 4}\end{array}$ & $\begin{array}{c}-1 \\
1-f_{X I} \\
f_{X I} \\
i C_{B M}-\left(1-f_{X I}\right)^{* i} C_{X S}-f_{X I}{ }^{*} i C_{X I} \\
{ }_{i} N_{B M}-\left(1-f_{X I}\right)^{*} i N_{X S}-f_{X I}{ }^{*} i N_{X I} \\
\mathrm{iP}_{\mathrm{BM}}-\left(1-f_{X I}\right)^{*} i P_{X S}-f_{X I}{ }^{*} i P_{X I}\end{array}$ & $\begin{array}{c}\mathrm{gCOD}_{\mathrm{BM}} / \mathrm{gCOD}_{\mathrm{BM}} \\
\mathrm{gCOD}_{, \mathrm{xS}} / \mathrm{gCOD}_{\mathrm{BM}} \\
\mathrm{gCOD}_{\mathrm{xl}} / \mathrm{gCOD}_{\mathrm{BM}} \\
\mathrm{gC} / \mathrm{gCOD} \mathrm{COM}_{\mathrm{BM}} \\
\mathrm{gN} / \mathrm{gCOD} \mathrm{BM}_{\mathrm{BM}} \\
\mathrm{gCOD}_{, \mathrm{xS}} / \mathrm{gCOD} \mathrm{B}_{\mathrm{BM}}\end{array}$ \\
\hline \multicolumn{4}{|c|}{$\rho_{17}-$ Aerobic growth of $\mathrm{X}_{\mathrm{NOB}}$ on $\mathrm{NO}_{3}{ }^{-}$} \\
\hline $\begin{array}{l}\alpha_{17,3} \\
\alpha_{17,9} \\
\alpha_{17,, 11} \\
\alpha_{17,12} \\
\alpha_{17,13} \\
\alpha_{11,1,15} \\
\alpha_{17,, 16} \\
\end{array}$ & $\begin{array}{l}\mathrm{X}_{\mathrm{NOB}} \\
\mathrm{S}_{\mathrm{C}} \\
\mathrm{S}_{\mathrm{NH}} \\
\mathrm{S}_{\mathrm{NO2}} \\
\mathrm{S}_{\mathrm{NO} 3} \\
\mathrm{~S}_{\mathrm{PO4}} \\
\mathrm{S}_{\mathrm{O} 2} \\
\end{array}$ & $\begin{array}{c}1 \\
-\mathrm{i} \mathrm{C}_{\mathrm{BM}} \\
-\mathrm{i} \mathrm{N}_{\mathrm{BM}} \\
-1 / \mathrm{Y}_{\mathrm{NOB}} \\
1 / \mathrm{Y}_{\mathrm{NOB}} \\
-\mathrm{i} \mathrm{P}_{\mathrm{BM}} \\
1-16 / 14^{*} 1 / \mathrm{Y}_{\mathrm{NOB}} \\
\end{array}$ & $\begin{array}{c}\mathrm{gCOD}_{\mathrm{BM}} / \mathrm{gCOD}_{\mathrm{BM}} \\
\mathrm{gC} / \mathrm{g} C O D_{\mathrm{BM}} \\
\mathrm{gN} / \mathrm{g} \mathrm{COD}_{\mathrm{BM}} \\
\mathrm{gN} / \mathrm{gCOD} \mathrm{BM}_{\mathrm{BM}} \\
\mathrm{gN} / \mathrm{gCOD} \mathrm{BM}_{\mathrm{BM}} \\
\mathrm{gP} / \mathrm{g} \mathrm{COD}_{\mathrm{BM}} \\
\mathrm{gO}_{2} / \mathrm{gCOD}_{\mathrm{BM}} \\
\end{array}$ \\
\hline \multicolumn{4}{|c|}{$\rho_{18}-$ Aerobic respiration of $X_{N O B}$} \\
\hline $\begin{array}{l}\alpha_{18,3} \\
\alpha_{18,9} \\
\alpha_{18,11} \\
\alpha_{18,, 15} \\
\alpha_{18,16} \\
\end{array}$ & $\begin{array}{l}\mathrm{X}_{\mathrm{NOB}} \\
\mathrm{S}_{\mathrm{IC}} \\
\mathrm{S}_{\mathrm{NH}} \\
\mathrm{S}_{\mathrm{PO} 4} \\
\mathrm{~S}_{\mathrm{O} 2} \\
\end{array}$ & $\begin{array}{l}-1 \\
\mathrm{iC}_{\mathrm{BM}} \\
\mathrm{i} \mathrm{N}_{\mathrm{BM}} \\
\mathrm{iP} \mathrm{P}_{\mathrm{BM}} \\
-1 \\
\end{array}$ & $\begin{array}{c}\mathrm{gCOD}_{\mathrm{BM}} / \mathrm{gCOD}_{\mathrm{BM}} \\
\mathrm{gC} / \mathrm{g} \mathrm{COD}_{\mathrm{BM}} \\
\mathrm{gN} / \mathrm{gCOD}_{\mathrm{BM}} \\
\mathrm{gP} / \mathrm{gCOD}_{\mathrm{BM}} \\
\mathrm{gO}_{2} / \mathrm{gCOD}_{\mathrm{BM}} \\
\end{array}$ \\
\hline \multicolumn{4}{|c|}{$\rho_{19}-$ Decay of $X_{\text {NOB }}$} \\
\hline $\begin{array}{l}\alpha_{19,3} \\
\alpha_{19,5} \\
\alpha_{19,6} \\
\alpha_{19,9} \\
\alpha_{19,11} \\
\alpha_{19,15} \\
\end{array}$ & $\begin{array}{l}X_{\mathrm{NOB}} \\
\mathrm{X}_{\mathrm{S}} \\
\mathrm{X}_{1} \\
\mathrm{~S}_{\mathrm{I}} \\
\mathrm{S}_{\mathrm{NH}} \\
\mathrm{S}_{\mathrm{PO4}}\end{array}$ & 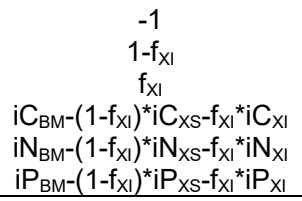 & $\begin{array}{c}\mathrm{gCOD}_{\mathrm{BM}} / \mathrm{gCOD}_{\mathrm{BM}} \\
\mathrm{gCOD}_{, \mathrm{xs}} / \mathrm{gCOD}_{\mathrm{BM}} \\
\mathrm{gCOD}_{\mathrm{xl}} / \mathrm{gCOD}_{\mathrm{BM}} \\
\mathrm{gC} / \mathrm{gCOD} \mathrm{BM}_{\mathrm{BM}} \\
\mathrm{gN} / \mathrm{gCOD} \mathrm{BM}_{\mathrm{BM}} \\
\mathrm{gP} / \mathrm{gCOD} \\
\mathrm{BM}\end{array}$ \\
\hline \multicolumn{4}{|c|}{$\rho_{20}-$ Dissolution of $\mathrm{O} 2$} \\
\hline \multicolumn{4}{|c|}{$\rho_{21}-$ Dissolution of $\mathrm{CO}_{2}$} \\
\hline \multicolumn{4}{|c|}{$\frac{\mathrm{U}_{21,9}}{\rho_{22}-\text { Dissolution of } \mathrm{NH}_{3}}$} \\
\hline
\end{tabular}


922 Reaction stoichiometry for algae growth on ammonium and nitrate is reported below (Equation SI4.1 and

SI4.2). Stoichiometric coefficients were computed in order to respect elemental and charge balance.

$$
\begin{aligned}
& 91 \mathrm{CO}_{2}+9 \mathrm{HCO}_{3}^{-}+11 \mathrm{NH}_{4}^{+}+\mathrm{HPO}_{4}^{2-}+64.5 \mathrm{H}_{2} \mathrm{O} \rightarrow \mathrm{C}_{100} \mathrm{H}_{183} \mathrm{O}_{48} \mathrm{~N}_{11} \mathrm{P}+114.75 \mathrm{O}_{2} \\
& 100 \mathrm{CO}_{2}+13 \mathrm{H}^{+}+11 \mathrm{NO}_{3}^{-}+\mathrm{HPO}_{4}^{2-}+84.5 \mathrm{H}_{2} \mathrm{O} \rightarrow \mathrm{C}_{100} \mathrm{H}_{183} \mathrm{O}_{48} \mathrm{~N}_{11} \mathrm{P}+136.75 \mathrm{O}_{2}
\end{aligned}
$$

924 The Chemical Oxygen Demand, (COD), associated to the algal biomass was estimated:

$$
\begin{gathered}
114.75\left[\frac{\mathrm{mol}_{\mathrm{O}_{2}}}{\mathrm{~mol}_{\mathrm{BM}}}\right] \cdot 32\left[\frac{\mathrm{g}_{\mathrm{O}_{2}}}{\mathrm{~mol}_{\mathrm{O}_{2}}}\right]=3672\left[\frac{\mathrm{g}_{\mathrm{COD}}}{\mathrm{mol} \mathrm{BM}_{\mathrm{BM}}}\right] \\
3672\left[\frac{\mathrm{g}_{\mathrm{COD}}}{\mathrm{mol} \mathrm{BM}_{\mathrm{BM}}}\right] / 2336\left[\frac{\mathrm{g}_{\mathrm{BM}}}{\mathrm{mol}_{\mathrm{BM}}}\right]=1.57\left[\frac{\mathrm{g}_{\mathrm{COD}}}{\mathrm{g}_{\mathrm{BM}}}\right]
\end{gathered}
$$

925 The stoichiometric equation also allows for the assessment of the mass of each element required for 926 biomass synthesis (i.e. ix,BM [gX gCOD-1], with X: C,N,O,P,H). As an example, in Equation SI4.5 the estimation of $\mathrm{i}_{\mathrm{N}, \mathrm{ALG}}$ related to reaction $\mathrm{SI} 4.1$ is reported. The same calculation was performed for $\mathrm{i}_{\mathrm{P}, \mathrm{BM}}^{\mathrm{ALG}}, \mathrm{i}_{\mathrm{O}, \mathrm{BM}}^{\mathrm{ALG}}$, $\mathrm{i}_{\mathrm{H}, \mathrm{BLM}}^{\mathrm{ALG}}$.

$$
\mathrm{i}_{\mathrm{N}, \mathrm{BM}}^{\mathrm{ALG}}: \frac{11\left[\frac{\mathrm{mol}}{\mathrm{mol}}\right] \cdot 14\left[\frac{\mathrm{g}_{\mathrm{N}}}{\mathrm{mol}_{\mathrm{N}}}\right]}{3672\left[\frac{\mathrm{g}_{\mathrm{COD}}}{\mathrm{mol}}\right]}=0.0419\left[\frac{\mathrm{g}_{\mathrm{N}}}{\mathrm{g}_{\mathrm{COD}}}\right]
$$

929 A similar approach was applied for the growth of the bacterial biomass. The biomass elementary composition 930 assumed for both heterotrophic and nitrifying bacteria was taken from Metcalf and Eddy (2014), i.e.

$931 \mathrm{C}_{60} \mathrm{H}_{87} \mathrm{O}_{23} \mathrm{~N}_{12} \mathrm{P}$.

$$
\begin{gathered}
\mathrm{C}_{60} \mathrm{H}_{86} \mathrm{O}_{23} \mathrm{~N}_{12} \mathrm{P}+62.5 \mathrm{O}_{2}+10 \mathrm{H}^{+} \rightarrow 60 \mathrm{CO}_{2}+12 \mathrm{NH}_{4}^{+}+\mathrm{HPO}_{4}^{2-}+23.5 \mathrm{H}_{2} \mathrm{O} \\
62.5\left[\frac{\mathrm{mol}_{\mathrm{O}_{2}}}{\mathrm{~mol}_{\mathrm{BM}}}\right] \cdot 32\left[\frac{\mathrm{g}_{\mathrm{O}_{2}}}{\mathrm{~mol}_{\mathrm{O}_{2}}}\right]=2000\left[\frac{\mathrm{g}_{\mathrm{COD}}}{\mathrm{mol}}\right] \\
2000\left[\frac{\mathrm{g}_{\mathrm{COD}}}{\mathrm{mol}}\right] / 1373\left[\frac{\mathrm{g}_{\mathrm{BM}}}{\mathrm{mol}_{\mathrm{BM}}}\right]=1.46\left[\frac{g_{\mathrm{COD}}}{\mathrm{g}_{\mathrm{BM}}}\right]
\end{gathered}
$$

932 It is worth emphasising that the Alba model accounts for $\mathrm{P}$ assimilation while existing models do rarely 933 consider $\mathrm{P}$ in the biomass raw formula.

934 Stoichiometric coefficients for hydrolysis and ammonification were computed by imposing the element 935 continuity, as shown earlier for algal growth. 
Table SI.5.1: Kinetic parameter values

Kinetic parameters

\begin{tabular}{|c|c|c|c|c|}
\hline Symbol & Description & Value \pm std & Unit & Source \\
\hline \multicolumn{5}{|c|}{ Biological model } \\
\hline$\mu_{\max , \mathrm{g}, \mathrm{ALG}}$ & Maximum specific growth rate of $\mathrm{X}_{\mathrm{ALG}}$ & $2.5 \pm 0.05$ & $d^{-1}$ & This study \\
\hline$\mu_{\text {max }, \mathrm{r}, \mathrm{ALG}}$ & Specific respiration rate of $X_{A L G}$ & 0.1 & $d^{-1}$ & This study \\
\hline$\mu_{\max , \mathrm{d}, \mathrm{ALG}}$ & Specific decay rate of $X_{A L G}$ & 0.03 & $d^{-1}$ & Arashiro, 2017 \\
\hline$\mu_{\text {max,g,H }}$ & Maximum specific growth rate of $X_{H}$ & 6 & $d^{-1}$ & Henze,2000 \\
\hline$\mu_{\max , \mathrm{r}, \mathrm{H}}$ & Specific aerobic respiration rate of $X_{H}$ & 0.3 & $d^{-1}$ & Reichert, 2001 \\
\hline$\mu_{\mathrm{Hyd}}$ & Hydrolysis rate of slowly biodegradable $\operatorname{COD}\left(\mathrm{X}_{S}\right)$ & 3 & $d^{-1}$ & Arashiro, 2017 \\
\hline$\mu_{\mathrm{a}}$ & Hydrolysis rate of urea (SND) & 0.25 & $d^{-1}$ & this study \\
\hline$\mu_{\max , \mathrm{d}, \mathrm{H}}$ & Specific decay rate of $X_{H}$ & 0.9 & $d^{-1}$ & This study \\
\hline$\mu_{\max , \mathrm{g}, \mathrm{AOB}}$ & Maximum specific aerobic growth rate of $\mathrm{X}_{\mathrm{AOB}}$ & $\begin{array}{c}0.72 \\
\pm 0.0005\end{array}$ & $d^{-1}$ & This study \\
\hline$\mu_{\max , \mathrm{r}, \mathrm{AOB}}$ & Specific aerobic respiration rate of $X_{A O B}$ & 0.05 & $d^{-1}$ & Arashiro, 2017 \\
\hline$\mu_{\max , \mathrm{d}, \mathrm{AOB}}$ & Specific decay rate of $\mathrm{X}_{\mathrm{AOB}}$ & 0.1 & $d^{-1}$ & Solimeno, 2017 \\
\hline$\mu_{\mathrm{max}, \mathrm{g}, \mathrm{NOB}}$ & Maximum specific aerobic growth rate of $\mathrm{X}_{\mathrm{NOB}}$ & $0.65 \pm 0.02$ & $d^{-1}$ & This study \\
\hline$\mu_{\text {max }, \text { r, NOB }}$ & Specific aerobic respiration rate of $X_{N O B}$ & 0.03 & $d^{-1}$ & Reichert, 2001 \\
\hline$\mu_{\max , \mathrm{d}, \mathrm{NOB}}$ & Specific decay rate of $\mathrm{X}_{\mathrm{NOB}}$ & 0.08 & $d^{-1}$ & this study \\
\hline $\mathrm{K}_{\mathrm{C}, \mathrm{ALG}}$ & Inorganic carbon half-saturation constant for $\mathrm{X}_{\mathrm{ALG}}$ & 0.004 & $\mathrm{gCm}^{-3}$ & Solimeno, 2017 \\
\hline $\mathrm{K}_{\mathrm{O}, \mathrm{ALG}}$ & Oxygen half-saturation constant for $\mathrm{X}_{\mathrm{ALG}}$ & 0.2 & $\mathrm{gO}_{2} \mathrm{~m}^{-3}$ & Reichert, 2001 \\
\hline $\mathrm{K}_{\mathrm{N}, \mathrm{ALG}}$ & Ammoniacal nitrogen half-saturation constant for $\mathrm{X}_{\mathrm{ALG}}$ & 0.1 & $\mathrm{gNm}^{-3}$ & Solimeno, 2017 \\
\hline $\mathrm{K}_{\mathrm{NO}, \mathrm{ALG}}$ & Nitrate half-saturation constant for $\mathrm{X}_{\mathrm{ALG}}$ & 0.3 & $\mathrm{gNm}^{-3}$ & $\begin{array}{c}\text { Decostere, } \\
2016\end{array}$ \\
\hline $\mathrm{K}_{\mathrm{P}, \mathrm{ALG}}$ & Phosphorus half-saturation constant for $\mathrm{X}_{\mathrm{ALG}}$ & 0.02 & $\mathrm{gNm}^{-3}$ & $\begin{array}{l}\text { Decostere, } \\
2016\end{array}$ \\
\hline $\mathrm{Ec}_{50,02}$ & Oxygen value associated to $50 \%$ algae growth reduction & 20 & $\mathrm{gO}_{2} \mathrm{~m}^{-3}$ & This study \\
\hline $\mathrm{n}$ & Shape parameter associated to the Hill model & 15 & {$[-]$} & This study \\
\hline $\mathrm{K}_{\mathrm{S}, \mathrm{H}}$ & Soluble organic matter half-saturation constant for $\mathrm{X}_{\mathrm{H}}$ & 4 & $\mathrm{gCODm}^{-3}$ & Jubani, 2007 \\
\hline$K_{0, H}^{, n}$ & Oxygen half-saturation constant for $\mathrm{X}_{\mathrm{H}}$ & 0.2 & $\mathrm{gO}_{2} \mathrm{~m}^{-3}$ & Henze, 2000 \\
\hline $\mathrm{K}_{\mathrm{N}, \mathrm{H}}$ & Ammonium half-saturation constant for $\mathrm{X}_{\mathrm{H}}$ & 0.05 & $\mathrm{gNm}^{-3}$ & Henze,2000 \\
\hline $\mathrm{K}_{\mathrm{NO} 2, \mathrm{H}}$ & Nitrite half-saturation constant for $\mathrm{X}_{\mathrm{H}}$ & 0.2 & $\mathrm{gNm}^{-3}$ & Reichert, 2001 \\
\hline $\mathrm{K}_{\mathrm{NO} 3, \mathrm{H}}$ & Nitrate half-saturation constant for $\mathrm{X}_{\mathrm{H}}$ & 0.5 & $\mathrm{gNm}^{-3}$ & Reichert, 2001 \\
\hline $\mathrm{K}_{\mathrm{P}, \mathrm{H}}$ & Phosphorus half-saturation constant for $X_{H}$ & 0.01 & $\mathrm{gPm}^{-3}$ & Henze,2000 \\
\hline $\mathrm{K}_{\mathrm{HYD}}$ & Half saturation constant for hydrolysis & 1 & $\mathrm{gCODgCOD}^{-1}$ & Reichert, 2001 \\
\hline $\mathrm{K}_{\mathrm{C}, \mathrm{AOB}}$ & Inorganic carbon half-saturation constant for $\mathrm{X}_{\mathrm{AOB}}$ & 0.5 & $\mathrm{gCm}^{-3}$ & Henze,2000 \\
\hline $\mathrm{K}_{\mathrm{O}, \mathrm{AOB}}$ & Oxygen half-saturation constant for $\mathrm{AOB}$ & 0.8 & $\mathrm{gO}_{2} \mathrm{~m}^{-3}$ & Henze,2000 \\
\hline $\mathrm{K}_{\mathrm{N}, \mathrm{AOB}}$ & Ammonium half-saturation constant for $\mathrm{X}_{\mathrm{AOB}}$ & 0.5 & $\mathrm{gNm}^{-3}$ & Reichert, 2001 \\
\hline$K_{P, A O B}$ & Phosphorus half-saturation constant for $\mathrm{X}_{\mathrm{AOB}}$ & 0.01 & $\mathrm{gPm}^{-3}$ & Henze,2000 \\
\hline $\mathrm{K}_{\mathrm{C}, \mathrm{NOB}}$ & Inorganic carbon half-saturation constant for $\mathrm{X}_{\mathrm{NOB}}$ & 0.5 & $\mathrm{gCm}^{-3}$ & Henze,2000 \\
\hline $\mathrm{K}_{\mathrm{O}, \mathrm{NOB}}$ & Oxygen half-saturation constant for $\mathrm{X}_{\mathrm{NOB}}$ & 2.2 & $\mathrm{gO}_{2} \mathrm{~m}^{-3}$ & $\begin{array}{l}\text { Wiesmann, } \\
1994\end{array}$ \\
\hline $\mathrm{K}_{\mathrm{NO} 2, \mathrm{NOB}}$ & Nitrite half-saturation constant for $\mathrm{X}_{\mathrm{NOB}}$ & 0.5 & $\mathrm{gNm}^{-3}$ & Reichert, 2001 \\
\hline $\mathrm{K}_{\mathrm{P}, \mathrm{NOB}}$ & Phosphorus half-saturation constant for $\mathrm{X}_{\mathrm{NOB}}$ & 0.01 & $\mathrm{gPm}^{-3}$ & Henze,2000 \\
\hline$\eta_{\text {ANOX }}$ & Efficiency reduction factor for denitrification process & 0.6 & {$[-]$} & De Kreuk,2006 \\
\hline lOPT & Optimal irradiance for $\mathrm{X}_{\mathrm{ALG}}$ & $300 \pm 3.81$ & $\mu \mathrm{mol} \mathrm{m} \mathrm{m}^{-2} \mathrm{~s}^{-1}$ & Martinez,2018 \\
\hline$\alpha$ & Initial slope of irradiance response curve & 0.01 & $\mu \mathrm{mol}^{-1} \mathrm{~m}^{2} \mathrm{~s}^{1}$ & This study \\
\hline$\varepsilon$ & Light extinction coefficient & 0.067 & $\mathrm{~m}^{2} \mathrm{~g} C O D^{1}$ & This study \\
\hline$\theta$ & Coefficient for temperature dependence for mass transfer & 1.024 & ${ }^{\circ} \mathrm{C}^{-1}$ & Ginot1994 \\
\hline$\theta_{H}$ & Temperature coefficient for $X_{H}$ decay & 1.07 & ${ }^{\circ} \mathrm{C}^{-1}$ & Henze,200 \\
\hline$\theta_{A O B}$ & Temperature coefficient for $\mathrm{X}_{\mathrm{AOB}}$ decay & 1.1 & ${ }^{\circ} \mathrm{C}^{-1}$ & Metcalf\&Eddy \\
\hline$\theta_{\text {NOB }}$ & Temperature coefficient for $X_{\text {NOB }}$ decay & 1.04 & ${ }^{\circ} \mathrm{C}^{-1}$ & Metcalf\&Eddy \\
\hline$\theta_{\text {ALG }}$ & Temperature coefficient for $\mathrm{X}_{\mathrm{ALG}}$ decay & 1.04 & ${ }^{\circ} \mathrm{C}^{-1}$ & Reichert,2001 \\
\hline$\theta_{H Y D}$ & Temperature coefficient for hydrolisis & $1.04 \pm 0.004$ & ${ }^{\circ} \mathrm{C}^{-1}$ & This study \\
\hline$\theta_{\text {AMM }}$ & Temperature coefficient for ammonification & $1.12 \pm 0.002$ & ${ }^{\circ} \mathrm{C}^{-1}$ & This study \\
\hline$T_{\max }^{A L G}$ & Maximum temperature threshold for $\mathrm{X}_{\mathrm{ALG}}$ & $42 \pm 0.51$ & ${ }^{\circ} \mathrm{C}$ & This study \\
\hline $\mathrm{T}_{\mathrm{opt}} \mathrm{ALG}$ & Optimal temperature for $\mathrm{X}_{\mathrm{ALG}}$ growth & $20 \pm 0.15$ & ${ }^{\circ} \mathrm{C}$ & This study \\
\hline$T_{\min }^{A L G}$ & Minimum temperature threshold for $\mathrm{X}_{\mathrm{ALG}}$ & $-10 \pm 1.52$ & ${ }^{\circ} \mathrm{C}$ & This study \\
\hline $\mathrm{T}_{\max }^{\mathrm{AOB}}$ & Maximum temperature threshold for $\mathrm{X}_{\mathrm{AOB}}$ & $40 \pm 0.82$ & ${ }^{\circ} \mathrm{C}$ & This study \\
\hline $\mathrm{T}_{\mathrm{opt}}^{\mathrm{AOB}}$ & Optimal temperature for $\mathrm{X}_{\mathrm{AOB}}$ growth & $24.5 \pm 0.23$ & ${ }^{\circ} \mathrm{C}$ & This study \\
\hline$T_{\min } \mathrm{AOB}$ & Minimum temperature threshold for $\mathrm{X}_{\mathrm{AOB}}$ & $-8 \pm 0.74$ & ${ }^{\circ} \mathrm{C}$ & This study \\
\hline $\mathrm{T}_{\max }{ }^{\mathrm{NOB}}$ & Maximum temperature threshold for $\mathrm{X}_{\mathrm{NOB}}$ & $38.5 \pm 6.08$ & ${ }^{\circ} \mathrm{C}$ & This study \\
\hline $\mathrm{T}_{\mathrm{opt}}^{\mathrm{NOB}}$ & Optimal temperature for $\mathrm{X}_{\text {NOB }}$ growth & $20 \pm 0.38$ & ${ }^{\circ} \mathrm{C}$ & This study \\
\hline
\end{tabular}




\begin{tabular}{|c|c|c|c|c|}
\hline \\
\hline $\mathrm{T}_{\min }^{\mathrm{NOB}}$ & Minimum temperature threshold for $\mathrm{X}_{\mathrm{NOB}}$ & $-8 \pm 0.90$ & ${ }^{\circ} \mathrm{C}$ & This study \\
\hline $\mathrm{T}_{\max }{ }^{\mathrm{H}}$ & Maximum temperature threshold for $X_{H}$ & $42 \pm 1.92$ & ${ }^{\circ} \mathrm{C}$ & This study \\
\hline $\mathrm{T}_{\mathrm{opt}} \mathrm{H}$ & Optimal temperature for $X_{H}$ growth & $25 \pm 0.08$ & ${ }^{\circ} \mathrm{C}$ & This study \\
\hline $\mathrm{T}_{\min }{ }^{\mathrm{H}}$ & Minimum temperature threshold for $X_{H}$ & $-3 \pm 2.79$ & ${ }^{\circ} \mathrm{C}$ & This study \\
\hline $\mathrm{pH}_{\max }{ }^{\mathrm{ALG}}$ & Maximum $\mathrm{pH}$ threshold for $\mathrm{X}_{\mathrm{ALG}}$ & $12 \pm 0.04$ & - & This study \\
\hline $\mathrm{pH}_{\text {opt }}^{A L G}$ & Optimal pH for $\mathrm{X}_{\mathrm{ALG}}$ growth & $8.4 \pm 0.07$ & - & This study \\
\hline $\mathrm{pH}_{\min }{ }^{\mathrm{ALG}}$ & Minimum $\mathrm{pH}$ threshold for $\mathrm{X}_{\mathrm{ALG}}$ & $2 \pm 0.56$ & - & This study \\
\hline $\mathrm{pH}_{\max }{ }^{\mathrm{AOB}}$ & Maximum $\mathrm{pH}$ threshold for $\mathrm{X}_{\mathrm{AOB}}$ & $12.4 \pm 0.11$ & - & This study \\
\hline $\mathrm{pH}_{\mathrm{opt}} \mathrm{AOB}$ & Optimal pH for $\mathrm{X}_{\mathrm{AOB}}$ growth & $8.1 \pm 0.08$ & - & This study \\
\hline $\mathrm{pH}_{\min }{ }^{\mathrm{AOB}}$ & Minimum $\mathrm{pH}$ threshold for $\mathrm{X}_{\mathrm{AOB}}$ & $5.8 \pm 0.36$ & - & This study \\
\hline $\mathrm{pH}_{\max } \mathrm{NOB}$ & Maximum $\mathrm{pH}$ threshold for $\mathrm{X}_{\mathrm{NOB}}$ & $12.1 \pm 0.46$ & - & This study \\
\hline $\mathrm{pH}_{\mathrm{opt}} \mathrm{NOB}^{\mathrm{N}}$ & Optimal pH for $\mathrm{X}_{\mathrm{NOB}}$ growth & $7.9 \pm 0.32$ & - & This study \\
\hline $\mathrm{pH}_{\min }{ }^{\mathrm{NOB}}$ & Minimum $\mathrm{pH}$ threshold for $\mathrm{X}_{\mathrm{NOB}}$ & $5 \pm 0.57$ & - & This study \\
\hline $\mathrm{pH}_{\max }{ }^{\mathrm{H}}$ & Maximum $\mathrm{pH}$ threshold for $\mathrm{X}_{\mathrm{H}}$ & $11.5 \pm 0.02$ & - & This study \\
\hline $\mathrm{pH}_{\text {opt }}^{\mathrm{H}}$ & Optimal pH for $X_{H}$ growth & $7 \pm 0.07$ & - & This study \\
\hline $\mathrm{pH}_{\min }{ }^{\mathrm{H}}$ & Maximum $\mathrm{pH}$ threshold for $\mathrm{X}_{\mathrm{ALG}}$ & $2 \pm 0.34$ & - & This study \\
\hline \multicolumn{5}{|c|}{ Gas-liquid exchange with atmosphere } \\
\hline $\begin{array}{l}\mathrm{K}_{\mathrm{L}} \mathrm{a} \\
\mathrm{H}_{\mathrm{O} 2}\end{array}$ & $\begin{array}{l}\text { Mass transfer coefficient for } \mathrm{O}_{2} \\
\text { Henry's constant for } \mathrm{O}_{2}\end{array}$ & $\begin{array}{c}34 \pm 0.1 \\
\mathrm{Eq}(\mathrm{SI} 6.3)\end{array}$ & \multirow{2}{*}{$\begin{array}{c}\mathrm{d}^{-1} \\
\mathrm{gO}_{2} \mathrm{~atm}^{-1} \mathrm{~m}^{-3} \\
\mathrm{gCO}_{2} \text { atm }_{3}^{-1} \mathrm{~m}^{-}\end{array}$} & $\begin{array}{l}\text { This study } \\
\text { Sander,2015 }\end{array}$ \\
\hline $\mathrm{H}_{\mathrm{CO} 2}$ & Henry's constant for carbon $\mathrm{CO}_{2}$ & $\mathrm{Eq}(\mathrm{SI} 6.4)$ & & Sander, 2015 \\
\hline $\mathrm{H}_{\mathrm{NH} 3}$ & Henry's constant for $\mathrm{NH}_{3}$ & $\mathrm{Eq}(\mathrm{SI} 6.5)$ & $\mathrm{gNH}_{3} \mathrm{~atm}_{3}^{-1} \mathrm{~m}^{-}$ & Sander, 2015 \\
\hline $\mathrm{D}_{\mathrm{O} 2}$ & Mass diffusion coefficient for $\mathrm{O}_{2}$ & $2.5 e-009$ & $\mathrm{~m}^{2} \mathrm{~s}^{-1}$ & Perry, 2007 \\
\hline $\mathrm{D}_{\mathrm{CO} 2}$ & Mass diffusion coefficient for $\mathrm{CO}_{2}$ & $2.1 \mathrm{e}-009$ & $m^{2} s^{-1}$ & Perry, 2007 \\
\hline$D_{\mathrm{NH} 3}$ & Mass diffusion coefficient for $\mathrm{NH}_{3}$ & $2.4 \mathrm{e}-009$ & $m^{2} s^{-1}$ & Perry, 2007 \\
\hline $\mathrm{p}_{02}$ & Partial pressure of $\mathrm{O}_{2}$ in gas phase & 0.21 & atm & This study \\
\hline $\mathrm{p}_{\mathrm{CO} 2}$ & Partial pressure of $\mathrm{CO}_{2}$ in gas phase & 0.0004 & atm & This study \\
\hline $\mathrm{p}_{\mathrm{NH} 3}$ & Partial pressure of $\mathrm{NH}_{3}$ in gas phase & $1.5 \mathrm{e}-006$ & atm & This study \\
\hline \multicolumn{5}{|c|}{ pH sub-model } \\
\hline $\mathrm{pka}_{\mathrm{CO} 2}$ & Acid dissociation constant for carbonic acid - bicarbonate balance & 6.37 & - & Batstone, 2002 \\
\hline $\mathrm{pka}_{\mathrm{HCO}}{ }^{-}$ & Acid dissociation constant for carbonic acid - bicarbonate balance & 10.33 & - & Batstone, 2002 \\
\hline $\mathrm{pka}_{\mathrm{NH} 4}^{+}$ & Acid dissociation constant for bicarbonate-carbonate balance & 9.25 & - & Batstone, 2002 \\
\hline pka ${ }_{\mathrm{HNO} 2}$ & Acid dissociation constant for ammonia-ammonium balance & 3.35 & - & Batstone, 2002 \\
\hline $\mathrm{pka}_{\mathrm{HNO}}$ & Acid dissociation constant for nitrous acid -nitrite balance & -1.64 & - & Batstone, 2002 \\
\hline pkaнзго4 & Acid dissociation constant for nitric acid-nitrate balance & 2.14 & - & Batstone, 2002 \\
\hline $\mathrm{pka}_{\mathrm{H} 2 \mathrm{PO} 4^{-}}$ & $\begin{array}{l}\text { Acid dissociation constant for phosphoric acid-dihydrogen phosphate } \\
\text { balance }\end{array}$ & 7.21 & - & Batstone, 2002 \\
\hline $\mathrm{pka}_{\mathrm{HPO}}{ }^{2-}$ & $\begin{array}{l}\text { Acid dissociation constant for dihydrogen phosphate-hydrogen } \\
\text { phosphate balance }\end{array}$ & 12.67 & - & Batstone, 2002 \\
\hline
\end{tabular}

940 See the method section and SI.8 for the details on the calibration strategy and SI.9 for the 941 computation of the parameter uncertainty from the Fisher information matrix. 


\section{SI.6 Explicit chemical equilibria, their dissociation constants with temperature dependence}

Table SI.6.1: pH sub-model equation system

\begin{tabular}{|c|c|c|}
\hline Description & Expression $\left[\mathrm{mol} \mathrm{m}^{-3}\right]$ & $\begin{array}{c}K_{A} \\
(293 K) \\
{[M]}\end{array}$ \\
\hline 1- Mass balance & $\frac{\mathrm{S}_{\mathrm{NH}}}{14}=\mathrm{NH}_{3}+\mathrm{NH}_{4}^{+}$ & \\
\hline 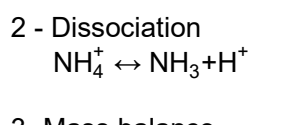 & $\mathrm{NH}_{4}^{+}=\left(\frac{\mathrm{S}_{\mathrm{NH}} / 14}{1+\frac{\left(\mathrm{Ka}_{\mathrm{NH} 4} \cdot 10^{3}\right)}{\mathrm{H}^{+}}}\right)$ & $\begin{array}{l}\mathrm{K}_{\mathrm{A}, \mathrm{NH} 4:} \\
5.62 \mathrm{E}-10\end{array}$ \\
\hline $\begin{array}{l}\text { 3- Mass balance } \\
4 \text { - Dissociation }\end{array}$ & $\frac{\mathrm{S}_{\mathrm{NO}_{2}}}{14}=\mathrm{NO}_{2}^{-}+\mathrm{HNO}_{2}$ & \\
\hline $\mathrm{HNO}_{2} \leftrightarrow \mathrm{NO}_{2}^{-}+\mathrm{H}^{+}$ & $\mathrm{HNO}_{2}=\left(\frac{\mathrm{S}_{\mathrm{NO}_{2}} / 14}{1+\frac{\left(\mathrm{Ka}_{\mathrm{NO}_{2}} \cdot 10^{3}\right)}{\mathrm{H}^{+}}}\right)$ & $\begin{array}{l}\mathrm{K}_{\mathrm{A}, \mathrm{HNO} 2:} \\
4.47 \mathrm{E}-04\end{array}$ \\
\hline 5- Mass balance & $\frac{\mathrm{S}_{\mathrm{NO}_{3}}}{14}=\mathrm{NO}_{3}^{-}+\mathrm{HNO}_{3}$ & \\
\hline $\begin{array}{l}6 \text { - Dissociation } \\
\qquad \mathrm{HNO}_{3} \leftrightarrow \mathrm{NO}_{3}^{-}+\mathrm{H}^{+}\end{array}$ & $\mathrm{HNO}_{3}^{-}=\left(\frac{\mathrm{S}_{\mathrm{NO}_{3}} / 14}{1+\frac{\left(\mathrm{Ka}_{\mathrm{NO}_{3}} \cdot 10^{3}\right)}{\mathrm{H}^{+}}}\right)$ & $\begin{array}{l}\mathrm{K}_{\mathrm{A}, \mathrm{HNOO}:} \\
4.37 \mathrm{E}+01\end{array}$ \\
\hline 7- Mass balance & $\frac{\mathrm{S}_{\mathrm{IC}}}{12}=\mathrm{CO}_{2}+\mathrm{HCO}_{3}^{-}+\mathrm{CO}_{3}^{2-}$ & \\
\hline $\begin{array}{l}8 \text { - Dissociation } \\
\mathrm{H}_{2} \mathrm{O}+\mathrm{CO}_{2} \leftrightarrow \mathrm{HCO}_{3}^{-}+\mathrm{H}^{+}\end{array}$ & $\mathrm{CO}_{2}=\frac{\mathrm{S}_{\mathrm{IC}} / 12}{1+\frac{\left(\mathrm{Ka}_{\mathrm{CO}_{2}}{ }^{*} 10^{3}\right)}{\mathrm{H}^{+}}+\frac{\left(\mathrm{Ka}_{\mathrm{CO}_{2}}{ }^{*} \mathrm{~K}_{\mathrm{aHCO} 3}{ }^{*} 10^{6}\right)}{\left(\mathrm{H}^{+}\right)^{2}}}$ & $\begin{array}{l}\mathrm{K}_{\mathrm{A}, \mathrm{H} 2 \mathrm{CO} O 3:} \\
4.27 \mathrm{E}-07\end{array}$ \\
\hline $\begin{array}{l}9 \text { - Dissociation } \\
\quad \mathrm{HCO}_{3}^{-} \leftrightarrow \mathrm{CO}_{3}^{2-}+\mathrm{H}^{+}\end{array}$ & $\mathrm{HCO}_{3}=\left(\frac{\mathrm{S}_{\mathrm{IC}} / 12}{1+\frac{\mathrm{H}^{+}}{\left(\mathrm{K}_{\mathrm{acos}^{*}}{ }^{\left.* 10^{3}\right)}\right.}+\frac{\left(\mathrm{Ka}_{\mathrm{HCO}_{3}} \mathrm{H}^{+} 0^{3}\right)}{\mathrm{H}^{+}}}\right)$ & $\begin{array}{l}\mathrm{K}_{\mathrm{A}, \mathrm{HCOO}:} \\
4.68 \mathrm{E}-11\end{array}$ \\
\hline 10- Mass balance & $\frac{\mathrm{S}_{\mathrm{PO} 4}}{31}=\mathrm{H}_{3} \mathrm{PO}_{4}+\mathrm{H}_{2} \mathrm{PO}_{4}^{-}+\mathrm{HPO}_{4}^{2-}+\mathrm{PO}_{4}^{3-}$ & \\
\hline $\begin{array}{l}11 \text { - Dissociation } \\
\mathrm{H}_{3} \mathrm{PO}_{4} \leftrightarrow \mathrm{H}_{2} \mathrm{PO}_{4}^{-}+\mathrm{H}^{+}\end{array}$ & $\mathrm{H}_{3} \mathrm{PO} 4=\frac{\mathrm{S}_{\mathrm{PO}_{4} / 31} / \frac{\left(\mathrm{Ka}_{\mathrm{H} 3 \mathrm{PO} 4}{ }^{*} 10^{3}\right)}{\mathrm{H}^{+}}+\frac{\left(\mathrm{Ka}_{\mathrm{H} 3 \mathrm{PO} 4}{ }^{*} \mathrm{~K}_{\left.\mathrm{aH} 2 \mathrm{PO}^{*}{ }^{*} 10^{6}\right)}\right.}{\left(\mathrm{H}^{+}\right)^{2}}+\frac{\left(\mathrm{Ka}_{\mathrm{H} 3 \mathrm{PO} 4}{ }^{*} \mathrm{~K}_{\mathrm{aH} 2 \mathrm{PO} 4}{ }^{*} \mathrm{~K}_{\mathrm{aHPO} 4}{ }^{*} 10^{9}\right)}{\left(\mathrm{S}^{+}\right)^{3}}}{131}$ & $\begin{array}{l}\mathrm{K}_{\mathrm{A}, \mathrm{H} 3 \mathrm{PP} \mathrm{O}:} \\
7.24 \mathrm{E}-03\end{array}$ \\
\hline $\begin{array}{l}12 \text { - Dissociation } \\
\mathrm{H}_{2} \mathrm{PO}_{4} \leftrightarrow \mathrm{HPO}_{4}^{2-}+\mathrm{H}^{+}\end{array}$ & 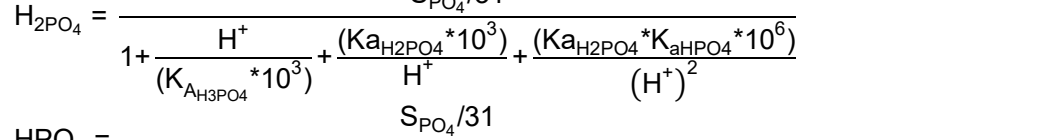 & $\begin{array}{l}\mathrm{K}_{\mathrm{A}, \mathrm{H} 2 \mathrm{PPO} 4:} \\
6.17 \mathrm{E}-08\end{array}$ \\
\hline $\begin{array}{l}13 \text { - Dissociation } \\
\mathrm{HPO}_{4}^{2-} \leftrightarrow \mathrm{PO}_{4}^{3-}+\mathrm{H}^{+}\end{array}$ & 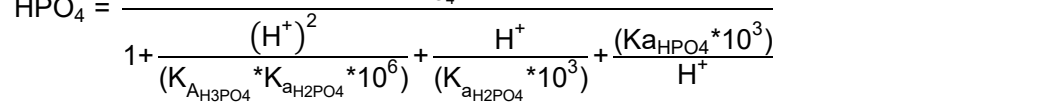 & $\begin{array}{l}\mathrm{K}_{\mathrm{A}, \mathrm{HPO}:} \\
2.14 \mathrm{E}-13\end{array}$ \\
\hline $\begin{array}{l}14 \text { - Dissociation } \\
\mathrm{H}_{2} \mathrm{O} \leftrightarrow \mathrm{OH}^{-}+\mathrm{H}^{+}\end{array}$ & $\mathrm{OH}^{-}=\frac{\mathrm{Ka}_{\mathrm{w}}{ }^{*} 10^{3}}{\mathrm{H}^{+}}$ & $\begin{array}{c}\mathrm{K}_{\mathrm{A}, \mathrm{W}}: \\
1.00 \mathrm{E}-14\end{array}$ \\
\hline 15 - Charge balance & $\mathrm{H}^{+}+\mathrm{NH}_{4}^{+}+\Delta_{\mathrm{CAT}, \mathrm{AN}}-\mathrm{OH}^{-}-\mathrm{NO}_{2}^{-}-\mathrm{NO}_{3}^{-}-\mathrm{HCO}_{3}^{-}-2 \mathrm{CO}_{3}^{2-}-\mathrm{H}_{2} \mathrm{PO}_{4}^{-}-2 \mathrm{HPO}_{4}^{2-}-3 \mathrm{PO}_{4}^{3-}=0$ & - \\
\hline
\end{tabular}

As matter of illustration, the implemented equations for bicarbonate are shown below. Through the derive the amount of $\mathrm{CO}_{2}, \mathrm{HCO}_{3}^{-}, \mathrm{CO}_{3}{ }^{2-}$, according to the $\mathrm{pH}$ simulated. Conversion factors are required for 
every chemical equilibrium to transform the mass (or COD) concentrations into molar concentrations. Total inorganic carbon (SIC in equation SI6.2) is divided for carbon molecular weight to obtain the value in [molC

$955 \mathrm{~m}^{-3}$, while acidity constants (Kaco2, Кансоз in equation SI6.2 and SI6.3) are multiplied for $10^{3}\left[\mathrm{I} \mathrm{m}^{-3}\right]$ and $10^{6}$ $956\left[1^{2} \mathrm{~m}^{-6}\right]$, since their value is typically reported in $[\mathrm{M}]$ in literature. The complete system of algebraic equations 957 of pH sub-model can be found in Table SI.6.1.

958

$$
\begin{gathered}
\frac{\mathrm{S}_{\mathrm{IC}}}{12}=\mathrm{CO}_{2}+\mathrm{HCO}_{3}^{-}+\mathrm{CO}_{3}^{2-} \\
\mathrm{CO}_{2}=\frac{\mathrm{S}_{\mathrm{IC}} / 12}{1+\frac{\mathrm{Ka}_{\mathrm{CO} 2} \cdot 10^{3}}{\mathrm{H}_{\mathrm{ION}}}+\frac{\mathrm{Ka}_{\mathrm{CO} 2} \cdot \mathrm{K}_{\mathrm{aHCO}_{3}} \cdot 10^{6}}{\mathrm{H}_{\mathrm{ION}}^{2}}} \\
\mathrm{HCO}_{3}^{-}=\frac{\mathrm{S}_{\mathrm{IC}} / 12}{1+\frac{\mathrm{H}_{\mathrm{ION}}}{\mathrm{Ka}_{\mathrm{CO} 2} \cdot 10^{3}}+\frac{\mathrm{Ka}_{\mathrm{HCO} 3} \cdot 10^{3}}{\mathrm{H}_{\mathrm{ION}}}}
\end{gathered}
$$

959 All the full set of equations are summarized in Table SI.6.1

960 The temperature influence on the dissociation constants was taken into account by using the van't Hoff 961 equation:

$$
\ln \left(\frac{\mathrm{K}_{\mathrm{a}, \mathrm{T}}}{\mathrm{K}_{\mathrm{a}, \mathrm{Tref}}}\right)=\frac{\Delta \mathrm{H}^{\circ}}{\mathrm{R}} \cdot\left(\frac{1}{\mathrm{~T}_{\text {ref }}}-\frac{1}{\mathrm{~T}+273.15}\right)
$$

962 In Equation SI6.4, $\mathrm{T}_{\text {ref }}$ is the standard temperature $(298.15 \mathrm{~K})$ for which the equilibrium coefficient value $963\left(\mathrm{~K}_{\mathrm{a}, \mathrm{Tref}},\left[\mathrm{mol} \mathrm{L}^{-1}\right]\right)$ is known, $\mathrm{T}$ is the temperature at which we want to know the equilibrium coefficient value $964\left(\mathrm{~K}_{\mathrm{a}, \mathrm{T}},\left[\mathrm{mol} \mathrm{L}^{-1}\right]\right), \mathrm{R}$ is the gas law constant $\left[\mathrm{J} \mathrm{K}^{-1} \mathrm{~mol}^{-1}\right]$ and $\Delta \mathrm{H}^{\circ}$ is the heat of reaction at standard 965 temperature and pressure [J ]. 
969 The different mass transfer coefficients were expressed as a function of the oxygen one (Sperandio, 1997):

$$
\frac{k L a_{j}}{k L a_{02}}=\left(\frac{D_{S j}}{D_{\mathrm{O} 2}}\right)^{0.5}
$$

970 where $D_{\mathrm{sj}}\left[\mathrm{m}_{2} \mathrm{~s}^{-1}\right]$ represents the diffusivity coefficient for the gas j. Combining equations SI7.1, SI7.2 and 11 971 (see Section 3.2.2), the following expression for the kinetics was obtained:

$$
\mathrm{Q}_{\mathrm{j}}=\mathrm{k}_{\mathrm{L}} \mathrm{a}_{\mathrm{O} 2}\left(\frac{\mathrm{D}_{\mathrm{Sj}}}{D_{\mathrm{O} 2}}\right)^{0.5}\left(\mathrm{H}_{\mathrm{Sj}} \mathrm{p}_{\mathrm{Sj}}-\mathrm{S}_{\mathrm{j}}\right)
$$

972 In Equation 20 the mass transfer coefficient (kıaO2), the Henry's constant $\left(\mathrm{H}_{\mathrm{Sj}}\right)$ and the diffusivity coefficient $973\left(D_{s j}\right)$ are temperature dependent. Temperature dependence is expressed by the Arrhenius law. The 974 temperature correction coefficient varies in the range 1.016-1.135, the value chosen in this study is 1.024 975 (Ginot et Hervé, 1994). Henry's constant temperature dependence acts in an opposite direction. Lower 976 temperatures correspond to higher gas solubility. The empirical functions proposed by Sander (2015) were 977 implemented, as shown below (Equation SI7.3, SI6.4 and SI7.5):

$$
\begin{aligned}
& \mathrm{H}_{\mathrm{O} 2}(\mathrm{~T})=42.15 \cdot \mathrm{e}^{1700\left(\frac{1}{273.15+\mathrm{T}^{-}} \frac{1}{298.15}\right)} \quad\left[\mathrm{gO}_{2} \mathrm{~m}^{-3} \mathrm{~atm}^{-1}\right] \\
& \mathrm{H}_{\mathrm{CO} 2}(\mathrm{~T})=\left[1511.13 \cdot \mathrm{e}^{2400\left(\frac{1}{273.15+\mathrm{T}} \frac{1}{298.15}\right)}\right] \cdot \frac{12}{44} \quad\left[\mathrm{gC}-\mathrm{CO}_{2} \mathrm{~m}^{-3} \mathrm{~atm}^{-1}\right] \\
& \mathrm{H}_{\mathrm{NH} 3}(\mathrm{~T})=\left[4.63 \cdot 10^{5} \cdot \mathrm{e}^{2100\left(\frac{1}{273.15+\mathrm{T}} \frac{1}{298.15}\right)}\right] \cdot \frac{14}{17} \quad\left[\mathrm{gN}^{\left.-\mathrm{NH}_{3} \mathrm{~m}^{-3} \mathrm{~atm}^{-1}\right]}\right.
\end{aligned}
$$

978 In Equation 20, the difference $\left(\mathrm{H}_{\mathrm{Sj}} \mathrm{p}_{\mathrm{Sj}}-\mathrm{S}_{\mathrm{j}}\right)$ for $\mathrm{CO}_{2}$ and $\mathrm{NH}_{3}$ must be written in order to consider only the form 979 really subjected to stripping/dissolution (i.e. CO2 and free ammonia). The complete expressions for gas980 liquid mass transfer are reported in Table SI.7.1.

Table SI.7.1. Gas-liquid mass transfer rates implemented in the ALBA model.

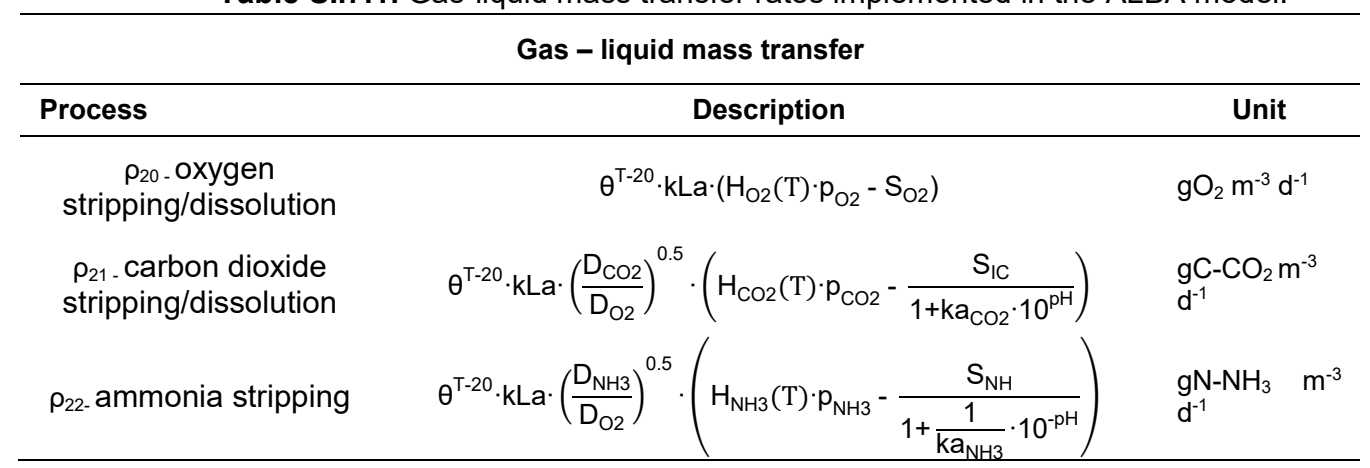


985 The model most sensitive parameters were determined using the available AQUASIM toolboxes for sensitivity analysis. The absolute-relative sensitivity function of model output $y_{i}$ to parameter $p_{j}$ is defined as 987 below:

$$
\partial_{y_{i}, p_{j}}^{\mathrm{a}, \mathrm{r}}=\frac{p_{j}}{y_{i}} \frac{\partial y_{i}}{\partial p_{j}}
$$

The sensitivity analysis was carried out accounting for the environmental conditions defining each season pattern (in terms of light, temperature and evaporation rate, see Fig.1), therefore the parameters reported in Tab. SI.8.1 are the resulting most sensitive ones in every season investigated. The sensitivity functions were estimated running simulations under established periodic regime (see description in section 2.2).

These parameters where then calibrated, using the procedure described in Section 2.2 (see Eq. 1). The experimental data of dissolved oxygen and $\mathrm{pH}$ collected by online probes in the periods $02-21 / 10 / 2018$ and $01-10 / 01 / 2019$ were considered in the criterion defined by equation (1) to calibrate the model. The model was then run with the new set of parameters and validated on 414 days of monitoring campaign, covering therefore all the seasons (see section 2.2 for details and Fig. 2 for simulation results).

Table SI.8.1. Most sensible parameters identified from the sensitivity analysis performed under periodic regime, the nominal and calibrated values with their standard deviation, including the most affected model variables.

\begin{tabular}{|c|c|c|c|c|c|c|c|c|}
\hline Parameter & \multicolumn{3}{|c|}{ Nominal value } & Reference & \multicolumn{3}{|c|}{ Calibrated value \pm std } & $\begin{array}{c}\text { Most affected } \\
\text { variables }\end{array}$ \\
\hline $\begin{array}{l}\text { Algae maximum specific } \\
\text { growth rate }\end{array}$ & \multicolumn{3}{|c|}{$1.5 \mathrm{~d}^{-1}$} & $\begin{array}{l}\text { [Solimeno et al. } \\
\text { 2019] }\end{array}$ & \multicolumn{3}{|c|}{$2.5 \pm 0.05 \mathrm{~d}^{-1}$} & $\mathrm{X}_{\mathrm{ALG}}, \mathrm{S}_{\mathrm{O} 2}, \mathrm{pH}$ \\
\hline $\begin{array}{l}\text { AOB maximum specific } \\
\text { growth rate }\end{array}$ & \multicolumn{3}{|c|}{$0.9 \mathrm{~d}^{-1}$} & $\begin{array}{l}\text { [Arashiro et al. } \\
\text { 2017] }\end{array}$ & \multicolumn{3}{|c|}{$0.72 \pm 0.005 \mathrm{~d}^{-1}$} & $\underset{\mathrm{pH}}{\mathrm{X}_{\mathrm{AOB}}, \mathrm{S}_{\mathrm{O} 2}, \mathrm{~S}_{\mathrm{NH}}, \mathrm{S}_{\mathrm{NO} 2},}$ \\
\hline $\begin{array}{l}\text { NOB maximum specific } \\
\text { growth }\end{array}$ & \multicolumn{3}{|c|}{$0.67 \mathrm{~d}^{-1}$} & $\begin{array}{l}\text { [Arashiro et al. } \\
\text { 2017] }\end{array}$ & \multicolumn{3}{|c|}{$0.65 \pm 0.02 \mathrm{~d}^{-1}$} & $\underset{p H}{\mathrm{X}_{\mathrm{NOB}}, \mathrm{S}_{\mathrm{O} 2}, \mathrm{~S}_{\mathrm{NO} 3}, \mathrm{~S}_{\mathrm{NO} 2},}$ \\
\hline Light dependence & \multicolumn{3}{|c|}{$275 \mu \mathrm{mol} \mathrm{m}{ }^{-2} \mathrm{~s}^{-1}$} & $\begin{array}{l}\text { [Martinez et al. } \\
\text { 2018] }\end{array}$ & \multicolumn{3}{|c|}{$300 \pm 3.81 \mu \mathrm{mol} \mathrm{m}{ }^{-2} \mathrm{~s}^{-1}$} & $\mathrm{X}_{\mathrm{ALG}}, \mathrm{S}_{\mathrm{O} 2}, \mathrm{pH}$ \\
\hline $\begin{array}{l}\text { Light extinction } \\
\text { coefficient }\end{array}$ & \multicolumn{3}{|c|}{$\begin{array}{c}0.067 \pm 0.001 \mathrm{~m}^{2} \\
\mathrm{gCOD}^{-1}\end{array}$} & [measured] & & $\mathrm{X}_{\mathrm{ALG}}, \mathrm{S}_{\mathrm{O} 2}, \mathrm{pH}$ \\
\hline Mass transfer coefficient & \multicolumn{3}{|c|}{$25 \mathrm{~d}^{-1}$} & [Decostere,2016] & \multicolumn{3}{|c|}{$34 \pm 0.1 \mathrm{~d}^{-1}$} & $\mathrm{SO}_{2}, \mathrm{pH}$ \\
\hline $\begin{array}{l}\text { Coefficient for } \\
\text { temperature correction } \\
\text { for hydrolysis }\end{array}$ & \multicolumn{3}{|c|}{1.07} & [Reichert,2001] & \multicolumn{3}{|c|}{$1.04 \pm 0.004$} & $\mathrm{~S}_{\mathrm{S}}, \mathrm{X}_{\mathrm{H}}, \mathrm{S}_{\mathrm{O} 2}$ \\
\hline \multirow[t]{2}{*}{$\begin{array}{l}\text { Coefficient for } \\
\text { temperature correction } \\
\text { for ammonification }\end{array}$} & \multicolumn{3}{|c|}{1.07} & [Reichert,2001] & \multicolumn{3}{|c|}{$1.12 \pm 0.002$} & $\underset{\mathrm{S}_{\mathrm{O} 2}}{\mathrm{~S}_{\mathrm{NH}}, \mathrm{X}_{\mathrm{AOB}}, \mathrm{X}_{\mathrm{NOB}}, \mathrm{pH}}$ \\
\hline & Min & Opt & Max & & Min & Opt & Max & \\
\hline $\begin{array}{l}\text { Algae temperature } \\
\text { dependence (CTMI) }\end{array}$ & 1.1 & 32.5 & 39.3 & $\begin{array}{c}\text { [Bernard \& } \\
\text { Rémond, 2012] }\end{array}$ & $-10 \pm 1.52$ & $20 \pm 0.15$ & $42 \pm 0.51$ & \multirow{4}{*}{$\begin{array}{l}\text { Biomass concentration, } \\
\text { nutrient removal rates, } \\
\mathrm{S}_{\mathrm{O} 2}, \mathrm{pH}\end{array}$} \\
\hline $\begin{array}{l}\text { AOB temperature } \\
\text { dependence (CTMI) }\end{array}$ & 5 & $\begin{array}{l}25- \\
35\end{array}$ & 35 & [Jubany 2007] & $-8 \pm 0.74$ & $24.5 \pm 0.23$ & $40 \pm 0.82$ & \\
\hline $\begin{array}{l}\text { NOB temperature } \\
\text { dependence (CTMI) }\end{array}$ & 5 & $\begin{array}{l}25- \\
30\end{array}$ & 37 & [Jubany 2007] & $-8 \pm 0.9$ & $20 \pm 0.38$ & $38.5 \pm 6.08$ & \\
\hline $\begin{array}{l}\text { Heterotrophs } \\
\text { temperature }\end{array}$ & 5 & 40 & 47 & $\begin{array}{c}\text { [Rosso et al. } \\
\text { 1995] }\end{array}$ & $-3 \pm 2.79$ & $25 \pm 0.08$ & $42 \pm 1.92$ & \\
\hline
\end{tabular}


dependence (CTMI

Algae $\mathrm{pH}$ dependence

(CPM)

\begin{tabular}{|c|c|c|c|c|c|c|c|}
\hline 2.24 & 7.34 & 10 & $\begin{array}{c}\text { [Ippoliti et al. } \\
2016]\end{array}$ & $2 \pm 0.56$ & $8.4 \pm 0.07$ & $12 \pm 0.04$ & \multirow{4}{*}{$\begin{array}{c}\text { Biomass concentration, } \\
\text { nutrient removal rates, } \\
\mathrm{S}_{\mathrm{O} 2}, \mathrm{pH}\end{array}$} \\
\hline 5.8 & $\begin{array}{c}7.8- \\
8\end{array}$ & 9 & [Jubany 2007] & $5.8 \pm 0.36$ & $8.1 \pm 0.08$ & $12.4 \pm 0.11$ & \\
\hline 6.5 & $\begin{array}{c}7.6- \\
8\end{array}$ & 8.6 & [Jubany 2007] & $5 \pm 0.57$ & $7.9 \pm 0.32$ & $12.1 \pm 0.46$ & \\
\hline 4 & 7 & 9 & $\begin{array}{c}\text { [Rosso et al. } \\
\text { 1995] }\end{array}$ & $2 \pm 0.34$ & $7 \pm 0.07$ & $11.5 \pm 0.02$ & \\
\hline
\end{tabular}

1000

NOB pH dependence

(CPM)

dependence (CPM)
deperoph 
1004 Once the model was calibrated and validated, a dynamic sensitivity analysis was run, accounting for all the period covered from the monitoring campaign (15/05/2018 - 01/08/2019) and therefore using the actual environmental conditions. The sensitivity functions were then computed in these real conditions for all the parameters reported in Table SI.8.1:

$$
\tilde{\partial}_{y_{i}, p_{j}}^{\mathrm{ar}}=\frac{\partial y_{i}}{\partial p_{j}}
$$

1008 The parameter standard deviation was then derived from the Fisher Information Matrix $F$. The Fisher 1009 analysis is based on the local sensitivity functions $\tilde{\partial}_{y_{i}, p_{i}}^{\text {a,r }}$, and turned out to be efficient for biological dynamic 1010 systems (Ejiofor et al., 1994; Vatcheva et al., 2006).

1011 The matrix $F$ was computed from the sensitivity matrix $\Delta Y_{p}$ (Eq. 24) and covariance matrix of measured 1012 standard deviation $C$ :

$$
\begin{gathered}
\Delta=\left[\frac{\partial y}{\partial p_{1}}, \ldots, \frac{\partial y}{\partial p_{m}}\right] \\
F=\sum_{k=1}^{K} \Delta^{T} C^{-1} \Delta
\end{gathered}
$$

1013 The standard deviation $\delta_{j}$ associated to parameters $p_{j}$ is then computed as:

$$
\delta_{j}^{2}=\left(F^{-1}\right)_{j, j}
$$


1017 After performing the sensitivity analysis and estimating the parameter standard error, as described in SI.9, 1018 the error propagation $\sigma_{y_{i}}$ of the model predictions for $y_{i}$ was computed as:

$$
\sigma_{y_{i}}(t)=\sqrt{\sum_{j=1}^{m}\left(\frac{\partial y_{i}}{\partial p_{j}}(t)\right)^{2} \sigma_{p_{j}}^{2}}
$$

1019 Where $p_{j}$ are the model parameters, $\sigma_{p_{j}}$ their standard deviations, $y_{i}\left(p_{1}, \ldots \ldots, p_{m}\right)$ is the model solution for each predicted state $y_{i}$ at a given time $t$ and $\sigma_{y_{i}}$ is the prediction standard deviation of the model result.

1021 Then, the $95 \%$ confidence intervals on model predictions (TSS, COD $, \mathrm{X}_{\mathrm{ALG}}, \mathrm{S}_{\mathrm{NH}}, \mathrm{S}_{\mathrm{NO} 2}, \mathrm{~S}_{\mathrm{NO} 3}$, $\mathrm{S}_{\mathrm{O} 2}$ and $\mathrm{pH}$ ) were estimated by the interval $\left[\begin{array}{ll}y_{i}-1.96 \sigma_{y_{i}} & y_{i}+1.96 \sigma_{y_{i}}\end{array}\right]$ shown in Fig.2, Section 4.2.2. 
1040 Table SI.11.1: Comparison among algae-bacteria models available in literature for wastewater remediation.

\begin{tabular}{|c|c|c|c|c|c|c|}
\hline & RWQM1 & PHOBIA & Modified ASM3 & BIO_ALGAE & BIO_ALGAE 2 & ALBA \\
\hline State variable $\left(n^{\circ}\right)$ & 24 & 16 & 16 & 19 & 19 & 17 \\
\hline $\begin{array}{c}\text { Biological processes } \\
\left(n^{\circ}\right)\end{array}$ & 18 & 13 & 21 & 18 & 18 & 19 \\
\hline Parameters $\left(n^{\circ}\right)$ & (n.s.) & 75 & 47 & 94 & 108 & $\begin{array}{c}135 \text { (including chemical } \\
\text { constants and their } \\
\text { temperature dependence) }\end{array}$ \\
\hline Growth kinetic type & Multiplicative & Minimum & Multiplicative & Multiplicative & Multiplicative & Multiplicative/Minimum* \\
\hline $\begin{array}{l}\text { Dependence on } \\
\text { organic and } \\
\text { inorganic carbon }\end{array}$ & COD & $\begin{array}{c}\mathrm{COD}, \mathrm{CO}_{2} \\
\mathrm{HCO}_{3}\end{array}$ & COD & $\begin{array}{c}\mathrm{COD}, \mathrm{CO}_{2} \\
\mathrm{HCO}_{3}\end{array}$ & $\begin{array}{c}\mathrm{COD}, \mathrm{CO}_{2} \\
\mathrm{HCO}_{3}\end{array}$ & $\mathrm{COD}, \mathrm{CO}_{2}, \mathrm{HCO}_{3}, \mathrm{CO}_{3}^{2-}$ \\
\hline Dependence on $\mathrm{N}$ & $\begin{array}{c}\mathrm{NH}_{3}, \mathrm{NH}_{4}{ }^{+}, \mathrm{NO}_{3}^{-}, \\
\mathrm{NO}_{2}^{-}\end{array}$ & $\mathrm{NH}_{3}{ }^{+}, \mathrm{NO}_{3}{ }^{-}$ & $\mathrm{NH}_{4}^{+}, \mathrm{NO}_{3}^{-}, \mathrm{NO}_{2}^{-}$ & $\begin{array}{c}\mathrm{NH}_{3}, \mathrm{NH}_{4}^{+}, \mathrm{NO}_{3}^{-} \\
, \mathrm{NO}_{2}^{-}\end{array}$ & $\begin{array}{c}\mathrm{NH}_{3}, \mathrm{NH}_{4}^{+}, \mathrm{NO}_{3}^{-} \\
, \mathrm{NO}_{2}^{-}\end{array}$ & $\begin{array}{c}\mathrm{Norg}, \mathrm{NH}_{3}, \mathrm{NH}_{4}^{+}, \mathrm{NO}_{3}^{-} \\
\mathrm{NO}_{2}^{-} \mathrm{HNO}_{2}, \mathrm{HNO}_{3} \\
\end{array}$ \\
\hline Dependence on $\mathrm{P}$ & $\mathrm{H}_{2} \mathrm{PO}_{4}^{-}, \mathrm{HPO}_{4}^{2-}$ & - & - & $\mathrm{SPO} 4\left({ }^{* *}\right)$ & SPO4 $\left({ }^{* * *}\right)$ & $\begin{array}{c}\mathrm{H}_{3} \mathrm{PO}_{4}, \mathrm{H}_{2} \mathrm{PO}_{4}^{--}, \mathrm{HPO}_{4}{ }^{2-} \\
\mathrm{PO}_{4}{ }^{3-}\end{array}$ \\
\hline $\begin{array}{l}\text { Continuity check } \\
\text { (mass conservation) }\end{array}$ & $\mathrm{C}, \mathrm{O}, \mathrm{N}, \mathrm{P}$ & (n.s.) & $(\mathrm{COD}, \mathrm{N}, \mathrm{P})$. & (n.s.) & (n.s.) & $\mathrm{C}, \mathrm{H}, \mathrm{O}, \mathrm{N}, \mathrm{P}, \mathrm{COD}$ \\
\hline $\begin{array}{l}\text { Algal biomass } \\
\text { composition }\end{array}$ & $\mathrm{C}_{100} \mathrm{H}_{232} \mathrm{O}_{26} \mathrm{~N}_{14} \mathrm{P}$ & (n.s.) & $\mathrm{C}_{106} \mathrm{H}_{181} \mathrm{O}_{45} \mathrm{~N}_{16} \mathrm{P}$ & $\mathrm{C}_{100} \mathrm{H}_{232} \mathrm{O}_{26} \mathrm{~N}_{14} \mathrm{P}$ & $\mathrm{C}_{100} \mathrm{H}_{232} \mathrm{O}_{26} \mathrm{~N}_{14} \mathrm{P}$ & $\mathrm{C}_{1000} \mathrm{H}_{183} \mathrm{O}_{48} \mathrm{~N}_{11} \mathrm{P}$ \\
\hline $\begin{array}{l}\text { Bacterial biomass } \\
\text { composition }\end{array}$ & $\mathrm{C}_{150} \mathrm{H}_{335} \mathrm{O}_{13} \mathrm{~N}_{30} \mathrm{P}$ & (n.s.) & $\mathrm{C}_{5} \mathrm{H}_{7} \mathrm{O}_{2} \mathrm{~N}$ & $\mathrm{C}_{150} \mathrm{H}_{335} \mathrm{O}_{13} \mathrm{~N}_{30} \mathrm{P}$ & $\mathrm{C}_{150} \mathrm{H}_{335} \mathrm{O}_{13} \mathrm{~N}_{30} \mathrm{P}$ & $\mathrm{C}_{60} \mathrm{H}_{87} \mathrm{O}_{23} \mathrm{~N}_{12} \mathrm{P}$ \\
\hline PAR model & Steele & Eilers \& Peters & Poisson & Eilers \& Peters & Eilers \& Peters & Bernard \& Remond \\
\hline $\mathrm{pH}$ model & $\begin{array}{c}\mathrm{NH}_{4}^{+}, \mathrm{NH}_{3}, \mathrm{CO}_{2}, \\
\mathrm{HCO}_{3} \mathrm{CO}_{3}^{2-} \\
\mathrm{H}_{2} \mathrm{PO}_{4}^{-}, \mathrm{HPO}_{4}^{2-} \\
\mathrm{Ca}^{2+}, \mathrm{H}^{+}, \mathrm{OH}^{-} \\
\end{array}$ & $\begin{array}{c}\mathrm{NH}_{4}^{+}, \mathrm{NH}_{3} \\
\mathrm{CO}_{2}, \mathrm{HCO}_{3} \\
\mathrm{CO}_{3}^{2-}, \mathrm{H}^{+}, \mathrm{OH}^{-} \\
\Delta \mathrm{CAT}, \mathrm{AN} \\
\end{array}$ & - & $\begin{array}{c}\mathrm{NH}_{4}^{+}, \mathrm{NH}_{3}, \mathrm{CO}_{2} \\
\mathrm{HCO}_{3} \mathrm{CO}_{3}^{2-}, \mathrm{H}^{+} \\
\mathrm{OH}^{-}\end{array}$ & $\begin{array}{c}\mathrm{NH}_{4}^{+}, \mathrm{NH}_{3}, \mathrm{CO}_{2} \\
\mathrm{HCO}_{3} \mathrm{CO}_{3}^{2-}, \mathrm{H}^{+} \\
\mathrm{OH}^{-}\end{array}$ & $\begin{array}{c}\mathrm{NH}_{4}^{+}, \mathrm{NH}_{3}, \mathrm{CO}_{2}, \mathrm{HCO}_{3} \\
\mathrm{CO}_{3}^{2-}, \mathrm{H}_{3} \mathrm{PO}_{4}, \mathrm{H}_{2} \mathrm{PO}_{4}^{--}, \\
\mathrm{HPO}_{4}^{2-}, \mathrm{PO}_{4}^{3-}, \mathrm{NO}_{2}^{-}, \mathrm{HNO}_{2}, \\
\mathrm{NO}_{3}^{-}, \mathrm{HNO}_{3}, \mathrm{H}^{+}, \mathrm{OH}^{-}, \Delta_{\mathrm{CAT}, \mathrm{AN}}\end{array}$ \\
\hline $\mathrm{pH}$ dependence & - & - & - & -- & CPMI & CPM \\
\hline $\mathrm{pH}$ control & - & Acid/Base & - & - & $\mathrm{CO}_{2}$ & $\mathrm{CO}_{2}$ \\
\hline $\begin{array}{l}\text { Temperature } \\
\text { dependence }\end{array}$ & Arrhenius & - & - & Arrhenius & CTMI & CTMI \\
\hline $\begin{array}{l}\text { Gas-liquid mass } \\
\text { transfer }\end{array}$ & $\mathrm{O}_{2}$ & - & - & $\mathrm{O}_{2}, \mathrm{CO}_{2}, \mathrm{NH}_{3}$ & $\mathrm{O}_{2}, \mathrm{CO}_{2}, \mathrm{NH}_{3}$ & $\mathrm{O}_{2}, \mathrm{CO}_{2}, \mathrm{NH}_{3}$ \\
\hline Evaporation & - & - & - & - & - & Bechet \\
\hline Reactor type & $\begin{array}{c}\text { River } \\
\text { environment }\end{array}$ & $\begin{array}{l}\text { Flow-lane } \\
\text { incubator }\end{array}$ & Photo-SBR & Raceway & Column PBR & Raceway \\
\hline Reactor installation & Outdoor & Indoor & Indoor & Outdoor & Indoor & Outdoor \\
\hline Reactor volume & - & $3 \mathrm{~L}$ & $2 \mathrm{~L}$ & $1 \mathrm{~m}^{3}$ & $4 \mathrm{~L}$ & $17 \mathrm{~m}^{3}$ \\
\hline Influent & $\begin{array}{c}\text { Wastewater } \\
\text { discharge }\end{array}$ & MM & DSC & MWW & MWW & SWW \\
\hline \multicolumn{7}{|l|}{ Calibration dataset } \\
\hline short-term dynamics & - & - & $\sqrt{ }(24 \mathrm{~h})$ & $\sqrt{ }(4 \mathrm{~d})$ & $\sqrt{ }(8 \mathrm{~d})$ & - \\
\hline long-term dynamics & - & - & - & & - & $i(30 d)$ \\
\hline $\begin{array}{l}\text { Calibrated } \\
\text { parameters st. dev. }\end{array}$ & $\sqrt{ }$ & - & $\sqrt{ }$ & & - & $\sqrt{ }$ \\
\hline \multicolumn{7}{|l|}{ Validation dataset } \\
\hline short-term dynamics & - & - & i (24 h) & $\sqrt{ }(4 \mathrm{~d})$ & $(?)$ & - \\
\hline long-term dynamics & - & - & - & $\sqrt{ }(175 d)$ & - & $\sqrt{ }(413 d)$ \\
\hline Sensitivity analysis & $\sqrt{ }$ & $\sqrt{ }$ & $\sqrt{ }$ & $\sqrt{ }$ & - & $\sqrt{ }$ \\
\hline Seasonal analysis & - & - & - & - & - & $\sqrt{ }$ \\
\hline $\begin{array}{l}\text { Parameter } \\
\text { Uncertainty }\end{array}$ & $\sqrt{ }$ & - & - & - & - & $\sqrt{ }$ \\
\hline $\begin{array}{l}\text { Confidence intervals } \\
\text { for model predictions }\end{array}$ & $\sqrt{ }$ & - & - & - & - & $\sqrt{ }$ \\
\hline Reference & Reichert, 2001 & Wolf, 2007 & Arashiro, 2017 & Solimeno, 2017 & Solimeno, 2019 & This work \\
\hline
\end{tabular}


1041 Abbreviations: V:implemented; (n.s.) not specified or provided in the relative publications; IC: Inorganic 1042 Carbon; DSC: Diluted Swine Centrate; MM: Mineral Medium; MWW: Municipal WasteWater; SWW: 1043 Synthetic Municipal WasteWater; CTMI: Cardinal Temperature Model with Inflection; CPMI: Cardinal pH 1044 Model with Inflection; CPM: Cardinal pH Model; $\left(^{*}\right)$ : in the ALBA model, only the Monod limitation terms relative to nutrients availability were implemented in the minimum function, while the dependence on inhibitory and environmental factors are multiplied for the minimum term (in the PHOBIA model, all the multiplicative terms considered are included in the minimum function); $\left({ }^{* *}\right) \mathrm{P}$ limitation term only on algae; $\left({ }^{* * *}\right) \mathrm{P}$ limitation term on algae and bacteria. 


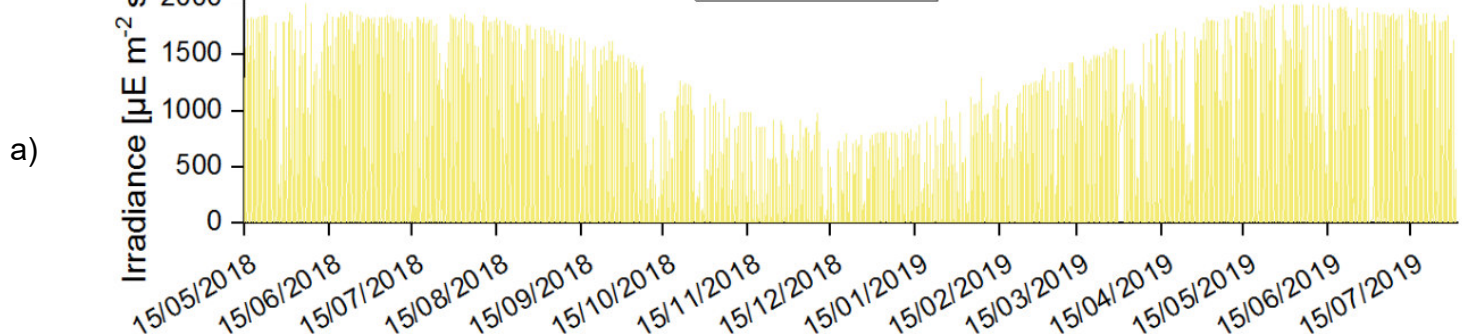

b)

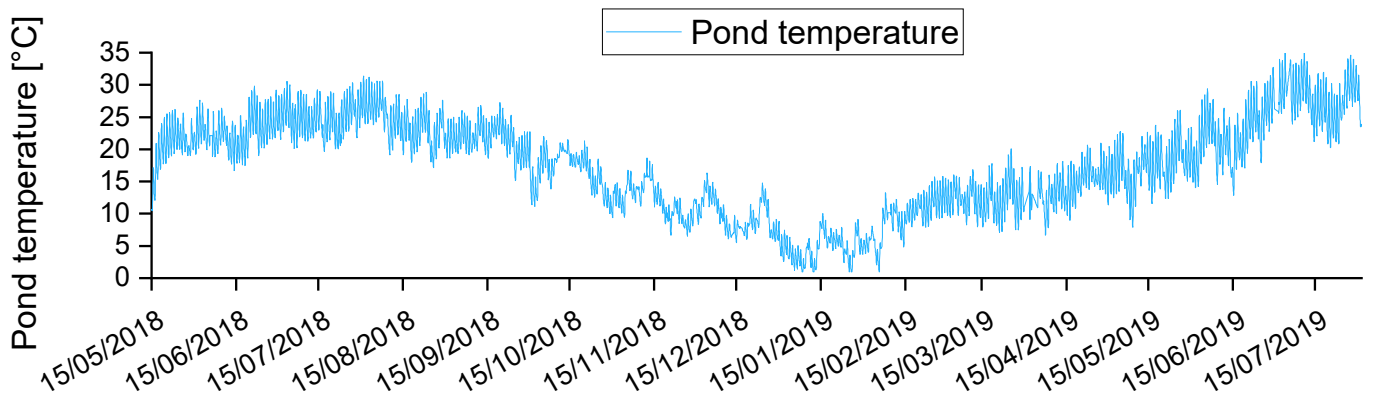

c)

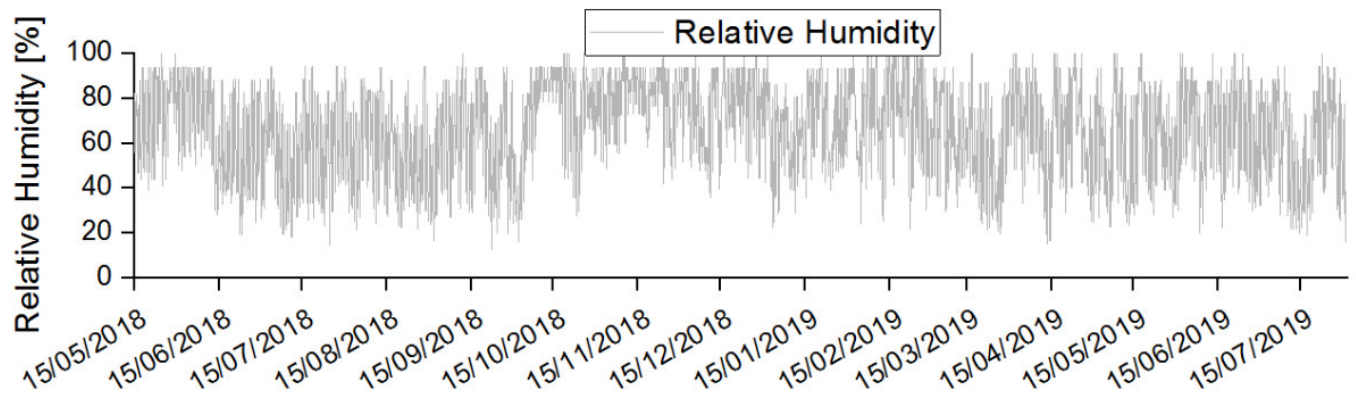

d)

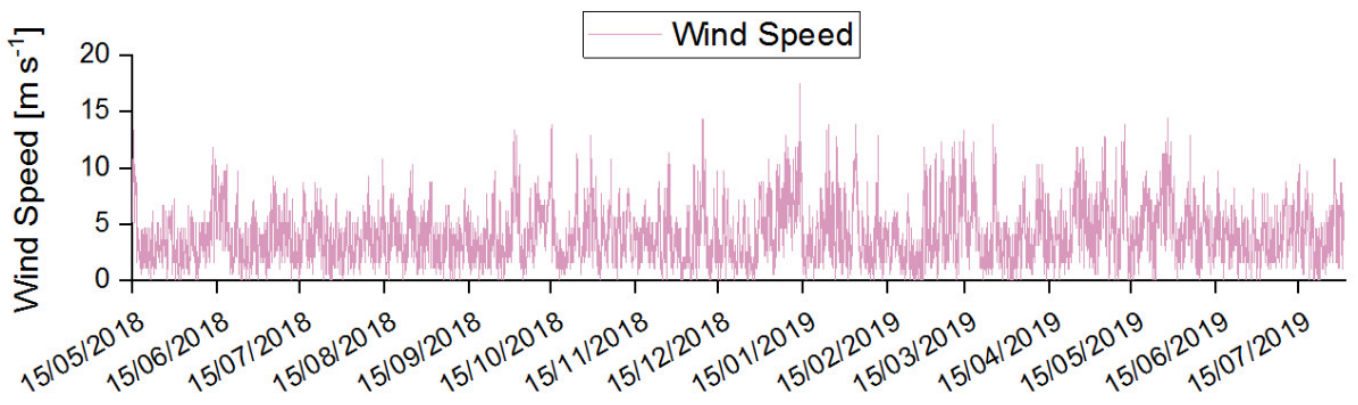

e)

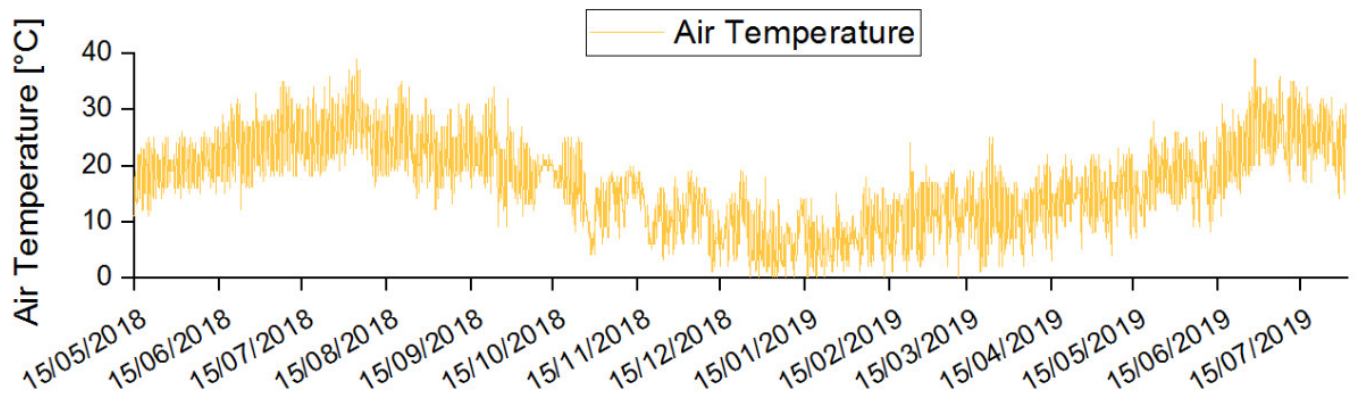




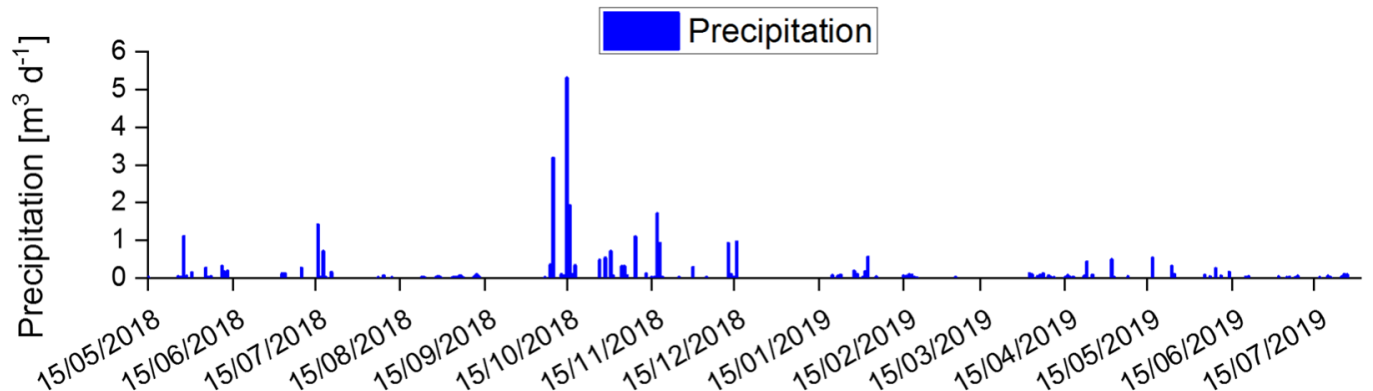

Figure SI.9.1: meteorological data used in the model: incident light on the raceway surface (a); water temperature inside the raceway (b); relative humidity (c), wind speed (d) and air temperature (e) used to compute the evaporation contribution; rain rate contribution (f) also accounted for the hydraulic balance. 
Arashiro, L. T., Rada-Ariza, A. M., Wang, M., Van Der Steen, P., \& Ergas, S. J., 2017. Modelling shortcut nitrogen removal from wastewater using an algal-bacterial consortium. Water Science and Technology, 75(4), 782-792.

Batstone, D. J., Keller, J., Angelidaki, I., Kalyuzhnyi, S. V., Pavlostathis, S. G., Rozzi, A., ... \& Vavilin, V. A., 2002. The IWA anaerobic digestion model no 1 (ADM1). Water Science and technology, 45(10), 65-73.

Bernard O. and Rémond B. Validation of a simple model accounting for light and temperature effect on microalgal growth. Bioresource Technology, 123, 520-527.

Decostere, B., De Craene, J., Van Hoey, S., Vervaeren, H., Nopens, I., \& Van Hulle, S. W., 2016. Validation of a microalgal growth model accounting with inorganic carbon and nutrient kinetics for wastewater treatment. Chemical Engineering Journal, 285, 189-197.

De Kreuk, M.K., Picioreanu, C., Hosseini, M., Xavier, J.B. and Van Loosdrecht, M.C.M., 2007. Kinetic model of a granular sludge SBR: influences on nutrient removal. Biotechnology and bioengineering, 97(4), 801-815.

Ejiofor, A. O., Posten, C. H., Solomon, B. O., \& Deckwer, W.-D. (1994). A robust fed-batch feeding strategy for optimal parameter estimation for baker's yeast production. Bioprocess Engineering, 11(4), 135-144.

Ginot, V. and Hervé, J.C., 1994. Estimating the parameters of dissolved oxygen dynamics in shallow ponds. Ecological modelling, 73(3-4), 69-187.

Henze, M., Gujer, W., Mino, T. and van Loosdrecht, M.C., 2000. Activated sludge models ASM1, ASM2, ASM2d and ASM3. IWA publishing, London, UK.

Ippoliti, D., Gómez, C., del Mar Morales-Amaral, M., Pistocchi, R., Fernández-Sevilla, J.M. and Acién, F.G., 2016. Modeling of photosynthesis and respiration rate for Isochrysis galbana (T-Iso) and its influence on the production of this strain. Bioresource technology, 203, 71-79.

Jubany Güell, I., 2007. Operation, modeling and automatic control of complete and partial nitrification of highly concentrated ammonium wastewater. Ph.D Thesis, Universitat Autònoma de Barcelona, Barcelona.

1080

Martínez, C., Mairet, F., \& Bernard, O., 2018. Theory of turbid microalgae cultures. Journal of theoretical biology, 456, 190-200.

Metcalf and Eddy, Inc. 2014. Wastewater engineering: treatment and resource recovery, $5^{\text {th }}$ ed. McGraw Hill, New York, USA.

Perry, R.H. and Green, DW, 2007. Perry's chemical engineers' handbook, $8^{\text {th }}$ ed. McGraw Hill, New York, USA.

Reichert, P., Borchardt, D., Henze, M., Rauch, W., Shanahan, P., Somlyódy, L. and Vanrolleghem, P., 2001. River water quality model no. 1 (RWQM1): II. Biochemical process equations. Water Science and Technology, 43(5), 11-30.

Rosso, L., Lobry, J.R., Bajard, S. and Flandrois, J.P., 1995. Convenient model to describe the combined effects of temperature and pH on microbial growth. Appl. Environ. Microbiol., 61(2), 610-616.

Sander, R., 2015. Compilation of Henry's law constants (version 4.0) for water as solvent. Atmos. Chem. Phys, 15(8), 4399-4981.

Solimeno, A., Parker, L., Lundquist, T. and García, J., 2017. Integral microalgae-bacteria model (BIO_ALGAE): Application to wastewater high rate algal ponds. Science of the total environment, 601, 646-657.

Solimeno A., Gómez-Serrano C., and Acién F. G., 2019. BIO_ALGAE 2: improved model of microalgae and bacteria consortia for wastewater treatment. Environmental Science and Pollution Reasearch, 26(259, 25855-25868.

Spérandio, M., \& Paul, E., 1997. Determination of carbon dioxide evolution rate using on-line gas analysis during dynamic biodegradation experiments. Biotechnology and bioengineering, 53(3), 243-252. quantitative models of dynamical systems. Artificial Intelligence, 170(4-5), 472-506. 
1100 Wolf G., Picioreanu C., and van Loosdrecht, M. C. M. Kinetic modeling of phototrophic biofilms: The PHOBIA model, 1101 Biotechnology and Bioengineering, 97(5), 1064-1079. 